NBER WORKING PAPER SERIES

\title{
SECURITIES LAWS, BANK MONITORING, AND THE CHOICE BETWEEN COV-LITE LOANS AND BONDS FOR HIGHLY LEVERED
}

\author{
Robert Prilmeier \\ René M. Stulz \\ Working Paper 25467 \\ http://www.nber.org/papers/w25467
NATIONAL BUREAU OF ECONOMIC RESEARCH
1050 Massachusetts Avenue
Cambridge, MA 02138
January 2019

We thank Mark Carey, Sergey Chernenko, Victoria Ivashina (EFA discussant), Justin Murfin, Greg Nini (AFA discussant), Mike Schwert, Phil Strahan, participants at presentations at City University of Hong Kong, Tulane University, the European Finance Association Meeting in Lisbon, the American Finance Association meeting in San Diego, and the FDIC Annual Bank Research Conference for helpful comments. We are grateful for excellent research assistance from Andrei Gonçalves, Byungwook Kim, and Leandro Sanz. The views expressed herein are those of the authors and do not necessarily reflect the views of the National Bureau of Economic Research.

At least one co-author has disclosed a financial relationship of potential relevance for this research. Further information is available online at http://www.nber.org/papers/w25467.ack

NBER working papers are circulated for discussion and comment purposes. They have not been peerreviewed or been subject to the review by the NBER Board of Directors that accompanies official NBER publications.

(C) 2019 by Robert Prilmeier and René M. Stulz. All rights reserved. Short sections of text, not to exceed two paragraphs, may be quoted without explicit permission provided that full credit, including $@$ notice, is given to the source. 
Securities Laws, Bank Monitoring, and the Choice Between Cov-lite Loans and Bonds for Highly Levered

Robert Prilmeier and René M. Stulz

NBER Working Paper No. 25467

January 2019, Revised June 2020

JEL No. D82,G18,G23,G32

\section{ABSTRACT}

In contrast to bonds, cov-lite loans do not require SEC registration and are not subject to securities laws. We show that this distinction plays an important role in firms' choice between funding through cov-lite loans and bonds and helps understand why the market share of cov-lite loans has been so high in recent normal times. Compared to cov-heavy loans, cov-lite loans are closer substitutes for bonds in that they have similar covenants, have tighter bid-ask spreads, have more trading, and are more likely to be used to refinance bonds than cov-heavy loans.

Robert Prilmeier

Tulane University

A.B. Freeman School of Business

7 McAlister Drive

New Orleans, LA 70118

rprilmei@tulane.edu

René M. Stulz

The Ohio State University

Fisher College of Business

806A Fisher Hall

Columbus, OH 43210-1144

and NBER

stulz@cob.osu.edu 


\section{Introduction}

There is a considerable literature that examines theoretically and empirically the choice of firms between borrowing from public markets and from banks. In this literature, reviewed in the next section, bank loans differ from bonds because banks monitor the borrower through covenants and have information that capital market investors do not have. This literature cannot explain why the typical leveraged loan outstanding is a cov-lite loan. Like bonds but unlike traditional bank loans, cov-lite loans do not have maintenance covenants. The absence of maintenance covenants means that the lender cannot monitor the loan at regular intervals, so that compared to a traditional bank loan, a cov-lite loan is an unmonitored loan.

Partly or mostly because of data availability, the literature has heavily focused on choices made by public firms. We argue in this paper that the literature misses an important dimension of the choices made by firms. A firm can only issue public bonds if it registers these bonds with the SEC and commits to regular filings. Hence, borrowing from the public markets would change drastically the public reporting requirements of a private firm. In contrast, borrowing in the form of a loan would have no impact on these requirements. Further, because of the Trust Indenture Act, the firms that issue bonds publicly face severe limitations in restructuring these bonds. Such legal limitations do not exist for bank loans (but they may be included in loan contracts as discussed in Demiroglu and James (2015)). Lastly, bonds are securities but loans are not, so that bonds issued by non-registrants, such as bonds issued pursuant to Rule 144a, are subject to securities laws.

We investigate in this paper whether the different legal status of bonds and loans is an important factor in firms' decisions to borrow in the form of loans or through issuance of bonds and in how loans are structured. If a firm borrows in the form of a loan but would prefer to raise funds through a bond issuance if not for the legal status of bonds, we would expect that firm to structure the loan so that it would be as similar to a bond as possible. We call the motivation to borrow in the form of loans because of their legal status the legal status motivation for loan issuance. We find that the legal status motivation plays an important role in firms' use of banks to raise funds through cov-lite loans and helps understand the dramatic 
growth of the cov-lite market following the global financial crisis (GFC). If firms value bond-like loans, we would expect the design of these loans to evolve so that they become better substitutes for bonds. We show that cov-lite loans have many features of bonds.

Though we show the importance of legal considerations in firms' loan and bond issuance decisions, we do not imply that other considerations raised in the literature are not relevant and provide further support for the role of some of these considerations. In particular, our evidence that cov-heavy loans have higher credit spreads than cov-lite loans for private firms is supportive of theories that covenants may have adverse selection costs for investors (Parlour and Plantin (2008)), that covenants may be costly because of coordination costs (Becker and Ivashina (2017)), and that monitoring may be better allocated to tranches of loans that do not involve institutional investors (Berlin, Nini, and Yu (2020)).

There is now a large literature documenting the drop in IPOs in the 2000s and the decrease in the willingness of firms to be publicly listed (see Doidge, Karolyi, and Stulz $(2013,2017)$ and Gao, Ritter, and Zhu (2013)). It is often argued that firms shy from the public markets in part because going public changes their disclosure obligations and puts them under the regulatory umbrella of the SEC. If the change in disclosure obligations leads firms to avoid going public, we would also expect private firms to refrain from issuing bonds publicly and would expect public firms that might want to go private to do the same. The role of SEC registration requirements in the decision of firms to borrow through loans instead of bonds is largely obscured by the fact that firm-level data is available almost exclusively for SEC registered firms. Any analysis of the decision to borrow through bonds or loans that uses a conventional database such as Compustat is limited to SEC registered firms. Yet, though the typical issuer of a bond is an SEC registered firm, the typical borrower through a highly levered loan is a private firm.

Historically, loans differed from bonds because loans were illiquid and held by banks that monitored borrowers while bonds were liquid and there was no bank-like monitoring for bond issuers. These sharp distinctions between loans and bonds started to disappear in the 1980s and the disappearance has accelerated. Now, firms that do not qualify for an investment-grade rating can borrow through loans that resemble bonds along many dimensions. Cov-lite loans enable firms to borrow in a way that is very similar 
to issuing a bond but without having to register the bond with the SEC and be subject to the disclosure requirements of securities laws and the Trust Indenture Act. The most important difference between covlite loans and bonds is that bonds are rarely secured while cov-lite loans almost always are. The development of cov-lite loans has made it cheaper for firms to stay private in that it has made the financing opportunities of private firms closer to the financing opportunities of public firms.

If covenant-lite loans are advantageous for firms because they effectively constitute bond financing without the disclosure requirements and without the restructuring restrictions of public bonds, we would expect cov-lite loans to be relatively more favored by firms not traded on exchanges and by firms that are more likely to exit exchanges. We find that this is the case. Firms that borrow through cov-lite loans are less likely to be public firms than firms that borrow through cov-heavy loans or bonds. Further, a public firm that borrows through a cov-lite loan is much more likely to exit public markets than a firm that borrows through a cov-heavy loan or a bond. Strikingly, firms refinancing a bond are more likely to borrow through a cov-lite loan than through a cov-heavy loan. Again, this evidence is supportive of the view that bonds and cov-lite loans are substitutes in a way that bonds and cov-heavy loans are not.

By borrowing through a cov-lite loan, a firm escapes disclosure requirements that it would have if it issued a public bond. However, for the cov-lite loan to be a substitute for issuing a public bond, it should be tradeable like a public bond and investors should require a similar credit spread for cov-lites and bonds adjusting for risk differences. Because loans are secured while bonds typically are not, we expect credit spreads to be lower for loans than for bonds. We find that this is the case. One way to interpret this result is that, if the main differences between cov-lite loans and registered bonds are the SEC registration of bonds and the fact that cov-lite loans are secured, investors place higher value on the fact that cov-lite loans are secured than on the benefits that accrue to bonds from registration. We show that the difference in credit spreads can plausibly be explained fully by the fact that loans are secured and bonds are not.

With a cov-heavy loan, lenders monitor the borrower and hence have information that outsiders do not have. As a result, an adverse selection problem arises that can make the market for a loan less liquid or illiquid as shown in Parlour and Plantin (2008). In contrast, the lack of maintenance covenants with cov- 
lite loans reduces the adverse selection problem that results from the lenders being better informed and hence increases the liquidity of the loans. To the extent that institutional cov-lite loans are often accompanied by a bank-held cov-heavy loan in the issuer’s capital structure (Berlin, Nini, and Yu, 2020), cov-lite issuance does not necessarily result in less bank monitoring. However, monitoring is costly. Bondholders do not have to expend these costs and cov-lites are designed so that the holders of the institutional tranche do not have to expend these costs either. This is because the cov-lite structure of the institutional tranche amounts to a pre-commitment not to acquire private information and not to monitor. Such a pre-commitment makes the cov-lite tranche more comparable to a bond and less informationally sensitive to private information than a cov-heavy tranche (Gorton and Pennacchi, 1990; Dang, Gorton, and Holmstrom, 2019).

Though we cannot directly compare the liquidity of cov-lite loans and the liquidity of high yield bonds, we show that the bid-ask spreads for cov-lite loans are not out of line with some estimates of trading costs for high-yield bonds. We also compare the credit spreads and liquidity of cov-heavy and cov-lite loans. Consistent with bank monitoring creating an adverse selection problem, we find that for private firms covlites have a lower credit spread than cov-heavy loans controlling for when the loan is entered into, for the characteristics of the loan, and for the issuer's credit rating and industry. Importantly, however, this credit spread difference could also be explained by issuer or issuance differences that are not observable to us. As expected, we find that cov-lite loans are substantially more liquid than cov-heavy loans. In particular, covlite loans start trading more quickly, have a higher break price, have lower bid-ask spreads, and trade more often. Consistent with an adverse selection problem, this liquidity advantage is greater for private firms, which tend to be more opaque.

As noted by Becker and Ivashina (2017), there is a cyclical pattern in cov-lite issuance. Specifically, cov-lite issuance increased sharply before the global financial crisis (GFC), essentially disappeared during the GFC and its immediate aftermath, and then increased at a fast pace. Not surprisingly, as cov-lite issuance fell sharply during the GFC, it also decreased sharply with the COVID-19 crisis (see IMF, 2020). The existence of such a pattern suggests that the costs and benefits of issuing cov-lite loans vary depending on 
business conditions. Diamond, Hu, and Rajan (2019) build a model where the value of maintenance covenants falls when liquidity is high as lenders are more concerned about the market value of a firm's assets than about their ability to appropriate its cash flows. We account for business conditions through year indicator variables and through a variable that measures the intensity of cov-lite issuance. We find as expected that a firm's probability of issuing a cov-lite loan increases when cov-lite issuance is more prevalent.

Our paper contributes to four literatures. First, there is a literature on the decrease in the number of listed firms. Our paper shows that firms' listing status and plans concerning that listing status if they are public affect their choice of debt financing and the structure of debt markets. The development of cov-lite loans is one factor that makes it less costly for firms to stay private or to delist voluntarily. Second, there is a literature that investigates how firms decide between borrowing through loans and through bond issuance. By combining bond-like features with the legal status advantages of a loan, cov-lite loans significantly expand the menu of choices available to firms. Third, there is a literature on loan trading and its implications for banks and borrowers. We show that for firms with the highest information asymmetries, namely the private firms, the adverse selection problem associated with covenants discussed in the literature may explain why cov-lite loans have lower credit spreads than cov-heavy loans. Fourth, there is an emerging literature on cov-lite loans. This literature so far focuses on the choice between cov-lite loans and covheavy loans as opposed to the use of cov-lite loans as substitutes for bonds. We show that the liquidity of cov-lite loans is close or equivalent to the liquidity of bonds.

We review the relevant literatures in the next section before developing our hypotheses. After presenting our data in section 3, we examine substitutability between bond issuance and cov-lite financing in section 4. In section 5, we examine differences in credit spreads and liquidity between cov-lite loans and bonds. In section 6, we show that cov-lite loans and cov-heavy loans differ in such a way that cov-lite loans are better substitutes for bonds. We conclude in section 7. 


\section{Review of the literature and hypothesis development}

In this section, we briefly review the relevant literatures and develop our main hypotheses. We first discuss the theoretical and empirical literature on the choice between raising funds through bank loans and through bond issuance. We then turn to the small literature on cov-lite loans before formulating our main hypotheses.

\subsection{The choice between bank loans and bonds}

Diamond (1991) provides a theory of the choice between bank loans and bonds. In his model, lenders are concerned about moral hazard but this concern differs across firms. The concern is more important for young firms than for firms that have developed a reputation as good borrowers. When the concern about moral hazard is important enough, firms borrow through bank loans that are monitored in contrast to bonds.

The distinction between monitored and unmonitored sources of finance is central to the literature. It would be inefficient for individual bondholders to monitor firms as each bondholder is likely to hold a small fraction of the bond issue (Berlin and Loeys (1988)). If monitoring is important, it is more efficient for a specialist to do so, namely a financial intermediary, and for investors to invest in the financial intermediary rather than in securities issued by corporate borrowers (Diamond (1984)). Covenants provide incentives for banks to monitor and enable them to take actions to reduce the risk of their loans (Rajan and Winton (1995)).

Coordination among bondholders makes renegotiation difficult. In addition, the Trust Indenture Act and bankruptcy laws complicate renegotiation by diffuse bondholders even more. In contrast, a loan held by a bank or a handful of lenders can be renegotiated more easily (but loan contracts may remove some of that flexibility as discussed in Demiroglu and James (2015)). Relatedly, specialized lenders such as banks have incentives to invest in making sure that they make the right decisions when a borrower is in distress, namely whether to renegotiate the loan or liquidate the firm (Chemmanur and Fulghieri (1994)).

Fama (1985) distinguishes between inside and outside debt. Bank loans are inside debt in that banks have access to information that public investors do not have. Banks acquire that information in a variety of 
ways that improve their ability to monitor. The fact that a bank has access to information that enables it to monitor more efficiently means that it will be willing to lend to a borrower with which it has a relationship in states of the world where arms-length investors will not be willing to lend (Bolton and Freixas (2000), Rajan (1992)). However, when banks have inside information, they effectively can hold up borrowers (Rajan (1992)). Consequently, firms may choose to have both bank debt and bonds in their capital structure.

The existing literature generally predicts that the safest firms issue bonds, less safe firms borrow from banks, and the least safe firms cannot borrow at all. Empirical evidence supports this view as Denis and Mihov (2003) find that "the primary determinant of the choice of debt source is the credit quality of the issuer.”

More recent literature has emphasized business conditions and loan supply effects in the choice between bank loans and bonds. Becker and Ivashina (2014) show evidence that firms that can borrow both from banks and from the capital markets switch to the capital markets for their funding when lending standards by banks are tight and bank share prices are low. Erel, Julio, Kim, and Weisbach (2011) show that the fund raising of non-investment grade borrowers is pro-cyclical, which implies that these borrowers raise fewer funds in tough times. Further, recent empirical literature shows that the riskiest firms often borrow from non-bank lenders (Chernenko, Erel, and Prilmeier (2018)).

\subsection{The choice of covenants}

The existing literature examines the determinants of the strictness of bank loan covenants for firms. A number of papers conclude that riskier firms have stricter covenants, which is consistent with the literature on bank loans discussed above (e.g., Berlin and Mester (1992), Billett, King, and Mauer (2007), and Rauh and Sufi (2010)). The literature also shows that maintenance covenants are frequently violated and that these violations have material implications for firm policies and firm performance (e.g., Chava and Roberts (2008), and Nini, Smith, and Sufi (2012)). Roberts and Sufi (2009) show that over 90\% of contracts with maturities of more than one year have a major contract term renegotiated. When a major contract term is changed, the syndicate participants generally have to be unanimous in approving the change. One would 
expect, therefore, that the covenant package depends on the size of the syndicate. Saavendra (2018) shows that it does. Loans with larger syndicates have fewer covenants that reduce flexibility in good states, such as covenants limiting capital expenditures. Firms with longer relationships with lenders have looser covenants (Prilmeier (2017)). As for the literature on the volume of bank loans, the literature explores the role of supply effects on covenant packages. Murfin (2012) shows that banks experiencing recent defaults tighten the covenant packages, which he attributes to lenders reassessing their screening ability.

\subsection{Why cov-lite loans?}

The literature on cov-lite loans is extremely limited. Ayotte and Bolton (2011) model the choice between cov-heavy and cov-lite loans. In their model, loans are securitized, so that investors have to expend reading costs to learn about loans. With a cov-lite loan, reading costs are low, but investors assume that any terms they do not know are adverse to them. With a cov-heavy loan, reading costs are high, but investors have lower moral hazard costs. In good times, expected moral hazard costs are lower, so that cov-lite loans are more advantageous. In their model, cov-lite loans are more liquid than cov-heavy loans because of lower reading costs. The model predicts pro-cyclical issuance of cov-lite loans. It also predicts that cov-lite loans have higher credit spreads and are more likely to be securitized.

Billett, Elkamhi, Popov, and Pungaliya (2016) use a different approach based on the existence of two agency problems with loans. One problem is between the borrower and the lender; the other problem is between the bank and the non-bank investors. In their model, the number of covenants increases as the bank participation in a loan falls, but only up to some threshold level of bank participation. The logic for this result is that the bank's incentive to monitor falls as it holds a smaller share of the loan. An increase in the number of covenants increases the bank's incentive to monitor. However, if the bank's skin in the game is really low, it may be optimal for the loan to be a cov-lite loan as the monitoring costs may be too high compared to the benefits of monitoring for some types of loans. The bank’s skin in the game will be pushed down if there is a lot of investor demand for loans or if the cost of capital for banks is high. In their model,

cov-lite loans have higher spreads than cov-heavy loans. The authors find that the value-weighted spread 
on a deal involving a cov-lite loan is higher and that loans sponsored by private equity groups are more likely to be cov-lite loans because these groups have reputation incentives that reduce moral hazard risks for investors.

Becker and Ivashina (2017) test three explanations for the growth of cov-lite loans. The first explanation is that borrowers, following the crisis, learned that renegotiation costs are high and are willing to pay to obtain unmonitored loans. The second explanation is that coordination costs for monitoring when a loan is held by many institutional investors are high, so that it can be optimal to have an unmonitored loan. The third explanation is that investors are chasing yields, so that they would rather have a higher yield with fewer protections. They find results that are strongly supportive of the coordination cost hypothesis. Berlin, Nini, and Yu (2020) investigate a large set of levered loan contracts. Like Becker and Ivashina (2017), they conclude that cov-lite loans reduce renegotiation frictions. They argue that the typical levered loan package with a cov-lite loan also has a cov-heavy tranche not held by institutional investors. This tranche has the traditional monitoring associated with banks. Hence, cov-lite packages put the lenders with a comparative advantage in monitoring, namely the banks, in charge of renegotiation.

Lastly, Diamond, Hu, and Rajan (2019) develop a theory where in boom times firm leverage depends mostly on the value of firm assets as debt can be repaid out of the proceeds from selling firm assets. In contrast, when liquidity goes away, loans are repaid out of cash flows and the pledgeability of cash flows becomes critical. Maintenance covenants increase pledgeability of cash flows, so that we would expect these covenants to be more important in periods of low liquidity. This theory suggests that covenant-lite loans are more likely to be issued in periods of high liquidity.

\subsection{Hypotheses development}

We observe equilibrium outcomes where a firm borrows either through a bond or through a levered loan. If the firm borrows through a levered loan, the loan either has maintenance covenants or it does not. For an equilibrium outcome to occur, there has to be an intersection of a demand curve for funds of a 
particular type from the borrower and of a supply curve for that type of funds from investors. In this section, we develop two hypotheses we investigate in the remainder of the paper. The first hypothesis is that a firm's decision to borrow through a cov-lite loan instead of a bond is affected by the legal status of loans and bonds (legal status hypothesis). The second hypothesis is that the cost of choosing to borrow with a covlite loan instead of a bond is low because cov-lite loans are designed so that they have attributes that make them acceptable substitutes for bonds for a subset of institutional investors (investor substitution hypothesis).

\section{4.a. The legal status hypothesis}

The existing literature focuses on the optimal choice of covenants conditional on the financing taking place through a loan, but we focus here on the choice between cov-lite loan issuance and bond issuance. Cov-lite loans are unmonitored loans and hence are more similar to bonds than to traditional monitored bank loans. If a loan and a bond have the same covenant package, a critical difference between a loan and a bond is that, under the current regulatory regime, a bond is a security while an investment in a syndicated loan is not (de Fontenay (2014)). If a bond is issued publicly, the issuer is subject to periodic disclosure requirements. Further, the bond is a security subject to the anti-fraud provisions of securities laws. As discussed later, a bond can also be issued subject to Rule 144a. With such an issuance, the bond is subject to securities laws but the issuer is not subject to periodic disclosures because of having issued the bond.

If a firm is a public firm subject to SEC regulation, issuing a bond publicly does not change its disclosure obligations. Hence, for such a firm, the fact that a loan is not a security has a limited disclosure benefit unless the firm expects that it might choose to deregister during the life of the bond. If the firm decides that it is better off private, it likely would have to buy back the bonds to avoid periodic disclosures, so that it would then have to raise funds through a leveraged loan. It is obviously easier for a firm that believes it likely that it will go private to raise funds through a loan in the first place.

Being subject to securities laws has both costs and benefits for firms issuing bonds. Investors benefit from greater protections, which can lead to a lower cost of funds. However, the public disclosures required 
in the bond offering and the subsequent periodic disclosures have costs for firms. First, there are administrative costs. Second, there are potential competitive costs, as a firm may have to disclose information publicly that is useful to its current or potential competitors. If a private firm issues a bond to the public that requires it to register the offering with the SEC, it essentially becomes a public firm. Some firms choose to become public through bond issuance. Glushkov, Khorana, Rau, and Zhang (2018) find that $18 \%$ of firms going public do so through bond issuance from 1987 to 2016 . Public firms are subject to the Sarbanes-Oxley Act, which imposes further obligations on firms. These obligations are controversial and many firms view them as costly. Lastly, and importantly, a lender through a loan can receive confidential information from a borrower that is not public information. An investor through a bond cannot receive such information.

The typical public firm is a firm listed on a major exchange. As shown by Doidge, Karolyi, and Stulz (2017), the propensity of firms to be listed in the US has fallen dramatically since 1997. Such a decrease in the propensity of firms to list must be the result of a decrease in the benefit from being listed and/or of an increase in the costs of being listed. If being public has become less attractive, it should make bond financing less attractive compared to bank loans for non-public firms. Firms that want to stop being SEC registered also would want to finance themselves with bank loans rather than bond issuance. If firms prefer bank loans to bond financing to avoid being SEC registered, we would expect them to choose bank loans that resemble bonds if such bank loans are available. Contractually, cov-lite loans are more similar to bonds than to typical bank loans. Like bonds, they do not have maintenance covenants.

This leads to our first hypothesis:

H1. Legal status motivation for loan issuance. Everything else equal, firms that find the legal status of bonds to be costly relative to the legal status of loans are more likely to borrow through loans than bonds and if they borrow through a loan are more likely to do so using a cov-lite loan. 
Empirically, an important dimension along which cov-lite loans often but not always differ from bonds is that most bonds are unsecured (see Benmelech, Kumar, and Rajan (2020) for the decline of use of collateral in bonds) and cov-lite loans are almost always secured. For borrowers, putting up collateral against borrowing is costly as it reduces financial flexibility (see Benmelech, Kumar, and Rajan (2020)). Hence, one might be concerned that if cov-lite borrowers have to put up collateral against their borrowing but bond issuers do not, this makes cov-lite loans less attractive compared to bonds. It is important to note that a cov-lite loan being secured while a bond is not secured is not a defining contractual difference between the two borrowing instruments because bonds can be secured. In our sample, $16 \%$ of bonds are secured. The advantage of security for a cov-lite loan is that it enhances a benefit of the cov-lite loan, which is the lack of monitoring costs. Having access to collateral means that the investors in a cov-lite loan do not have to be as informed about the firm than they would otherwise have to be. Though allowing a borrower to modify the collateral would be difficult in a bond because of the large number of investors, it is much easier for a loan. Consequently, the loss of financial flexibility that arises because of collateralization may be quite limited with a cov-lite loan.

For firms, cov-heavy loan issuances and Rule 144a issuances are ways to borrow without having to register with the SEC. Cov-lite loans could be poor substitutes for bonds compared to cov-heavy loans for issuers. Cov-heavy loans potentially benefit from monitoring that cov-lite loans do not benefit from. ${ }^{1}$ This monitoring makes the loans safer to the extent that coordination costs, free-riding costs, and adverse selection costs are not too high. Hence, cov-heavy loans could have lower spreads than cov-lite loans, which would weaken our hypothesis that legal status is an important consideration in the decision to borrow through a cov-lite loan. Alternatively, firms can issue bonds without having to register the issue as a public issuance using a Rule 144a offering. A Rule 144a bond differs from a loan in that it is a security subject to

\footnotetext{
${ }^{1}$ Even if the cov-lite loan is accompanied by a cov-heavy tranche, there may be frictions that limit the effectiveness of bank monitoring from the institutional investors' perspective. For example, Billett et al. (2016) find that the bank revolver accompanying a cov-lite often has so-called springing covenants that are inactive until the borrower draws down a certain proportion of the line of credit.
} 
securities laws. Again, if the credit spread on a Rule 144a bond were to be sufficiently low compared to a cov-lite loan, this would weaken our hypothesis.

\section{4.b. Investor substitution hypothesis}

Historically, public bond markets met large financing needs of companies. In the $19^{\text {th }}$ century, the bond market was a major source of funding for railroads. Though small firms could meet their financing needs through bank loans, eventually, as a firm became large and established, it would have to access the bond market. Banks face regulatory limits and risk management limits on how much they can lend to an individual firm. If the amounts that firms can borrow through bank loans are smaller than what they can borrow through the bond market, then firms can prefer loans to bonds because of their legal status only up to a given size. When banks are limited in how much of a loan they can hold, they can sell parts of the loan to non-bank investors. For the amount raised through loans to be comparable to amounts that can be raised through bonds, banks have to make investment in loans attractive to institutional investors so that some investors are willing to buy positions in loans instead of bonds. ${ }^{2}$ However, these loans cannot be structured in such a way as to make them much more expensive than bonds, since from the borrower's perspective expensive loans would be poor substitutes for bonds besides the legal status difference.

Loans are better substitutes for bonds for institutional investors concerned about liquidity if they are tradable under conditions similar to bonds. The literature on the trading of loans predicts that when banks have valuable non-public information loan trading is limited because of the resulting adverse selection problem (Parlour and Plantin (2008)). With cov-lite loans, institutional lenders have less information than with cov-heavy loans because they do not monitor maintenance covenants. Although banks could hold a cov-heavy tranche issued by the same borrower so that monitoring benefits still apply (Berlin, Nini, and $\mathrm{Yu}, 2020$ ), the banks do not participate in trading the institutional tranche, except potentially as market

\footnotetext{
${ }^{2}$ It is important to note that there are institutional investment vehicles such as CLOs or certain mutual funds that are contractually or legally restricted to either investing in loans or bonds. However, substitution can still occur at the level of the institutional investors that invest in these vehicles, and substitutability of loans vs. bonds will affect flows from these end investors into vehicles that either invest in loans or bonds.
} 
makers. With this structure, institutional investors have no incentive to monitor the lender, so that they do not have to expend monitoring costs. The lack of maintenance covenants therefore amounts to a precommitment not to monitor. With this pre-commitment, the cov-lite loan is less information sensitive than a cov-heavy loan. As a result, the cov-lite loan is more similar to a bond than it would be if it were more information sensitive and made it optimal for its holders to monitor. In this sense, the cov-lite loan can be structured similarly to a bond that may or may not be accompanied by a traditional loan, allowing the bondholders to trade in debt that is less informationally sensitive while the bank monitors the information sensitive debt. Hence, we would expect cov-lite loans to be more liquid than cov-heavy loans. Note that if cov-heavy loans were more liquid, then this would suggest that in some dimensions cov-heavy loans would be better substitutes for bonds.

If cov-lites are designed to be substitutes for registered bonds for investors who do not monitor, we would expect these loans to be rated since bonds typically are, revealing a preference of such investors for information production by rating agencies. Further, evidence that investors require a higher credit spread for cov-lites than comparable bonds would suggest that bonds have advantages for investors that cov-lites do not have since otherwise we would expect cov-lites to have lower credit spreads. The difficulty in comparing yields for bonds and yields for cov-lites is that cov-lite loans, as already discussed, are typically secured but bonds are not. Consequently, we would expect cov-lites to have a lower spread compared to bonds as long as investors do not value the benefits of securities laws more than they value the fact that cov-lites are secured. It follows from this that evidence that cov-lites trade at a higher spread than bonds would be evidence against our substitution hypothesis.

The substitution hypothesis is about cov-lites being designed so that some investors are willing to hold cov-lite loans instead of bonds without asking for a costly premium to do so. Obviously, some institutional investors cannot switch between bonds and loans because their investment mandate restricts them to invest either in loans, such as CLOs, or in bonds, but the hypothesis only requires that there are investors who view cov-lite loans and bonds as substitutes.

Our second hypothesis is therefore: 
H2. Investor substitution hypothesis. If cov-lite loans are designed to be substitutes for bonds for investors so that firms would not have to pay investors more for borrowing through a cov-lite loan than a bond, we would expect cov-lite loans to be rated, to trade more similarly to bonds than cov-heavy loans, and their credit spreads should not be higher than those of bonds.

\section{The data}

We create two samples: a leveraged loan sample and a speculative grade debt sample. The leveraged loan sample includes 5,560 loans by US issuers on the US leveraged loan market from January 1, 2005 through April 30, 2015. ${ }^{3}$ Our main data source is Capital IQ Leveraged Commentary and Data (LCD). The sample is limited to deals that LCD reports as completed as of May 12, 2015 (the date of our data extract). The LCD database provides information on loan characteristics such as the size, yield spread, and maturity of each loan facility. Importantly, it identifies covenant-lite facilities and second lien facilities. Unlike data available to academic researchers in DealScan, the LCD data allow us to determine what portion of the loan amount actually represents new money and they contain information on the borrower's first lien bank loan rating along with the corporate credit rating. In addition, LCD focuses primarily on loan originations, with $83 \%$ of the recorded deals consisting entirely of new money and the remainder consisting of amendments. By contrast, for a random sample of 114 firms, Roberts (2015) finds that 59\% of DealScan observations are originations and $41 \%$ are renegotiations, and DealScan does not distinguish between the two. To enhance comparability with bonds, for which only original issuance is observable, we limit the leveraged loan sample to originations.

The speculative grade debt sample includes both bonds and leveraged loans. Because $96 \%$ of covenantlite loans are rated and fewer than $2 \%$ of covenant-lite loans have an investment grade rating, this sample focuses on all leveraged loans and bonds that have a speculative grade rating at the time of issuance. Bond

\footnotetext{
${ }^{3}$ We exclude financial firms and utilities from both of our samples.
} 
issuance data during the sample period from January 1, 2005 through April 30, 2015 are taken from Mergent FISD. We exclude private placements, foreign currency bonds, global offerings, convertible, putable, and exchangeable bonds. We include bonds issued pursuant to Rule 144a. The speculative grade debt sample contains 7,759 deals, of which 4,413 are bonds.

Following Billett et al. (2016), we classify all leveraged loans that contain a covenant-lite facility as covenant-lite. ${ }^{4}$ The remaining leveraged loans are referred to as covenant-heavy. For bonds, we distinguish between public bonds that are registered with the SEC and bonds issued pursuant to Rule 144a. Bonds issued through Rule 144a can be subsequently registered with the SEC. Fenn (2000) documents that in his sample period, domestic speculative-grade Rule 144a bonds are almost always subsequently registered with the SEC. Subsequently, Huang and Ramirez (2010) reach a similar conclusion. We use the action type field in Mergent FISD to distinguish Rule 144a bonds that were subsequently exchanged from those that were never exchanged.

Several of our analyses require matching LCD loan observations to DealScan. We match loans based on the identity of the borrower, identity of the lead arranger, approximate origination date, ${ }^{5}$ as well as the size, yield spread, and maturity of the loan tranches. We require substantial overlap in tranche characteristics, but do not require all characteristics to match since the two databases may record the same loan differently. For example, DealScan contains tranche type classifications that are not reported as separate types in LCD, such as bridge loans or delay draw term loans, and whose mapping can be ambiguous. We are able to match 91\% of LCD borrowers and 70\% of LCD loan observations to DealScan.

\footnotetext{
${ }^{4}$ While covenant-lite loan facilities are generally structured as term loans B, roughly half of the deals that contain a covenant-lite facility also contain a revolving line of credit. Billett et al. (2016) examine 53 such revolvers in detail and conclude that $49 \%$ of revolvers accompanied by a covenant-lite facility have no maintenance covenants, $40 \%$ have springing covenants, and only $11 \%$ have traditional maintenance covenants. By contrast, in a recent paper, Berlin et al. (2018) argue that most covenant-lite loan facilities are accompanied by a tranche that does contain maintenance covenants. One reason for the difference in findings is that, as Berlin et al. (2018) show, firms that borrow using a covenant-lite term loan often already have a revolver with maintenance covenants in their capital structure. Further, Berlin et al. (2018) classify springing covenants as heavy, while Billett et al. (2016) classify them as lite. In any event, as discussed in section 2.4, a borrower that has both covenant-lite and covenant-heavy loans at the same time can be compared to a borrower that issues both a bond and a traditional bank loan.

${ }^{5}$ Origination dates cannot be matched exactly since LCD reports the date on which a loan launches for syndication, while DealScan reports the date on which the deal closes, with launch dates reported only for a subset of the deals.
} 
The most frequent reason for a failure to match is that, for about 20\% of LCD loan observations, DealScan does not record any loan observation for that borrower within 180 days after the LCD launch date.

We match borrowers to Compustat based on name and date, making use of the spedis function in SAS along with manual verification of similar names in Capital IQ. For loans that match to DealScan, we also obtain matches to Compustat from the link file provided by Chava and Roberts (2008). Compustat borrowers are matched to Capital IQ using GVKEY. We perform another name match to link nonCompustat borrowers to Capital IQ since this database includes privately held firms. Of the 2,830 distinct borrowers in the leveraged loan sample, we are able to find 52\% in Compustat and 98\% in Capital IQ. Bankruptcy announcement dates are obtained from Capital IQ.

Two databases are used to gauge the liquidity of the leveraged loans in the secondary trading market. The CRSP mutual fund database provides information on loan shares held by loan participation mutual funds on a monthly basis along with mark-to-market prices as of the reporting date. Changes in shares held from month to month allow us to infer that a given mutual fund traded shares in the loan. We match loans to the CRSP mutual fund database using the security name indicated in CRSP. These data are consistently available from June 30, 2010 onwards.

We obtain secondary market loan pricing data from the Thomson Reuters/LSTA Mark-to-market pricing service. These data are available to us for the period of January 2010 through December 2016. We calculate bid-ask spreads as the difference between the average bid quote and the average ask quote divided by the average ask quote multiplied by 100 . As a measure of market depth, the data also report on the number of brokers providing a quote. Figure 1 shows the evolution of total new money raised by speculative grade borrowers from 2005 through April 2015. To avoid undercounting covenant-heavy loans, which are more frequently unrated than cov-lite loans, we include unrated leveraged loans when constructing this graph even though we are not including them in the speculative grade sample. Note that unrated leveraged loans on average have a spread of 378 basis points above LIBOR (median of 350 basis points), comparable to the average loan of a $\mathrm{B}+$ rated issuer (mean spread of 387 basis points, median of 375 basis points). Figure 1 shows that prior to the GFC, covenant-heavy loans were the most important source of debt funding 
for speculative grade borrowers. There was a brief first wave of covenant-lite loans immediately prior to the GFC, but issuance of such instruments ceased almost entirely during the GFC. Although bond markets recovered more quickly from the GFC than the leveraged loan market, after 2010 almost all growth in the speculative grade debt market is driven by covenant-lite loans. ${ }^{6}$ By 2014, the majority of leveraged loans are cov-lite loans, and total issuance volume of cov-lite loans is as large as total bond issuance. Obviously, as already discussed, the importance of cov-lite loans depends on the stage of the business cycle, so the importance of these loans changes with the COVID-19 crisis.

\section{Cov-lite loan issuance versus bond issuance}

In this section, we investigate the legal status hypothesis. With this hypothesis, firms are more likely to raise funds with a cov-lite loan than a public bond if they are private or are likely to become private. To examine the hypothesis, we use our sample of speculative grade debt issuance, which includes both loans and bonds with a non-investment grade rating and excludes unrated issuers. Table 1 provides univariate comparisons of cov-lite loans with public bonds (Panel A) and Rule 144a private placements (Panel B). We first compare cov-lite loans and issuers to public bonds and issuers. A simple alternative hypothesis to the legal status hypothesis is that firms use cov-lite loans because the size of their debt issuance is too small to justify accessing the public bond market. Table 1 shows that there is no support for this alternative hypothesis as cov-lite loans are considerably larger than bond issuances. The average size of cov-lite loans in our sample is $\$ 839$ million compared to $\$ 530$ million for public bonds. It would make sense for a firm to use bank lending if the maturity of the debt is short. Though the maturity of cov-lite loans is shorter than the maturity of public bonds, the average maturity of cov-lite loans is slightly more than six years, so that maturity is not a reason for issuing a cov-lite loan instead of a bond. Practically all cov-lite loans are senior secured, while most bonds are senior unsecured. Among speculative grade borrowers, cov-lite loans have slightly higher ratings, with a median rating of B+ compared to B for bonds.

\footnotetext{
${ }^{6}$ This effect is even more pronounced when excluding unrated leveraged loans.
} 
Some of the theories discussed in Section 2 predict that younger firms are more likely to use bank debt. However, there is no difference in the average or the median firm age between cov-lite issuers and bond issuers. For a subset of our speculative debt sample, issuers are SEC filers and we can obtain balance sheet data for them. Compared to bond issuers, cov-lite issuers that file with the SEC have similar firm size, lower pre-existing leverage, a higher current ratio, and lower asset tangibility in the form of property, plant and equipment. Average profitability is the same between cov-lite issuers and bond issuers.

Panel B compares cov-lite loans and issuers to Rule 144a bonds and issuers. The biggest difference between Panel A and Panel B is the size of the issue. The average and median sizes for cov-lite loans are much larger than for Rule 144a bonds. For average size, the average cov-lite issue is for $\$ 839$ million in contrast to the average size of a Rule 144a bond issue of \$484 million.

We now turn to a test of two key predictions of the regulatory legal status hypothesis: 1) cov-lite loans attract unregistered issuers, and 2) they attract issuers that intend to deregister. Table 2 suggests that both effects are present. In this table, we count issuers as unregistered if they were not previously registered with the SEC. An issuer is considered registered with the SEC if we are able to obtain data on total assets for the fiscal year prior to debt issuance. Although Compustat tracks substantially all publicly traded firms, the database does not adequately track firms registered with the SEC that do not have publicly listed equity. Therefore, we search for additional asset data in Capital IQ, examining the filing source to make sure that the asset data we find comes from an SEC filing. We are able to find additional asset data for 668 observations by non-public firms compared to the 1,132 observations that Compustat does track. Thus, Compustat tracks only about $63 \%$ of SEC registered firms with no public equity.

One reason a bond issuer might be registered with the SEC is because of the bond issue itself. Because the registration statement includes asset data for the previous two years, we would find asset data in Compustat/Capital IQ for an issuer who was not registered with the SEC prior to the bond issue. To assess accurately the choices of previously unregistered firms, we treat such privately held first-time bond issuers as unregistered. We identify them by checking whether asset data are already available three years prior to 
bond issuance and making sure that SDC does not report any initial public offering for the firm during those three years. $^{7}$

As already discussed, many Rule 144a bond offerings are subsequently registered. These registrations typically take the form of an exchange of the Rule 144a bond for a registered bond. Hence, Table 2 distinguishes between Rule 144a offerings that were subsequently exchanged and those that were never exchanged. Table 2 shows that roughly two thirds of Rule 144a bonds are subsequently exchanged during our sample period.

About $51 \%$ of cov-lite issuers are unregistered, compared to $42 \%$ of cov-heavy issuers, $43 \%$ of Rule 144a bond issuers that never exchange the bond, 19\% of Rule 144a bond issuers who subsequently exchange the bond, and $15 \%$ of public bond issuers. In addition, among registered firms, cov-lite borrowers are much more likely to deregister within three years after debt issuance than other borrowers. About 19\% of cov-lite issuers deregister subsequently, compared to $10 \%$ of cov-heavy issuers and only about $3 \%$ of issuers of public bonds and 3\% of issuers of Rule 144a bonds that are subsequently exchanged, and 7\% of Rule 144a bond issuers that never exchange the bond. ${ }^{8}$

Existing theories of the decision to borrow through bank debt versus through bond issuance are not well-equipped to address the facts in Table 2. No theory we know of predicts that a cov-lite issuer is more likely to be a firm that does not currently file with the SEC or will stop filing within three years rather than a SEC filer. This result is especially surprising since the opposite result holds for cov-heavy loans. A covheavy issuer is more likely to be a filer than a non-filer or a firm that will stop filing within three years.

\footnotetext{
${ }^{7}$ We do not apply this criterion to loan issuances since they do not create registration requirements. We do apply the same criterion to Rule 144a private placements since domestic issuers frequently register their privately placed bonds subsequent to issuance (Fenn, 2000; Huang and Ramirez, 2010). Note that, if anything, this approach may cause us to understate the difference in prior registration status between bond and loan issuers.

${ }^{8}$ The reader may wonder whether firms deregister due to distress or mergers. We note that we code bankrupt issuers as well as issuers that subsequently become a merger target as not having deregistered. Within three years after issuance, $4 \%$ of bond issuers are bankrupt, compared to $2.2 \%$ of cov-heavy loan borrowers and $1.9 \%$ of cov-lite loan borrowers. For 176 deregistering loan borrowers we can also observe secondary market loan quotes. We examine the last known bid-ask midpoint up to three years after loan origination. We find that the loans of $9 \%$ of covenant-heavy borrowers that subsequently deregister are priced as distressed (i.e. less than 90 cents per dollar of principal), compared to $7 \%$ of covenant-lite loans.
} 
Although the tabulation in Table 2 is suggestive, it is clear from Table 1 that issue characteristics and firm characteristics differ across the five types of debt instruments. To account for these differences, we model the choice between a cov-lite loan, a cov-heavy loan, a public bond, an exchanged Rule 144a bond, and a Rule 144a bond that is never exchanged using a multinomial logit model that controls for firm age, deal maturity and size, rating as well as year and industry fixed effects. We use the LCD industry classification to create industry fixed effects. After filtering out utilities and financial firms, we have firms belonging to 31 industries. Table 3 reports relative risk ratios for the multinomial logit model with public bonds acting as the base outcome. The model includes indicator variables for unregistered firms and registered firms that deregister within three years after debt issuance, so that continuously registered firms act as the base group. Compared to continuously registered firms, unregistered firms are considerably more likely to issue cov-lite loans, with a relative risk ratio of 7.75 . This estimate implies that the ratio of the number of cov-lite loans issued to the number of public bonds issued is 7.75 times larger for unregistered firms than for registered firms. Unregistered firms are generally more likely to issue loans than bonds, as evidenced by the relative risk ratio of 6.75 for cov-heavy loans. A Wald test of the difference in coefficients between cov-lite and cov-heavy loans is not significant with a $p$-value of 0.173 . In section 6 , we show that the difference is statistically significant at the $5 \%$ level when controlling for additional loan characteristics that are not available for the bond sample.

Compared to registered firms, previously unregistered firms are also more likely to issue Rule 144a bonds, with a relative risk ratio of 1.26 for firms that subsequently exchange their bonds and 4.34 for firms that do not exchange them. The difference between these two coefficients is highly significant with a $p$ value of 0.000 . Although issuing a Rule 144a bond that is never exchanged could be viewed as an alternative way to issue debt without maintenance covenants and without SEC registration, a comparison of the relative risk ratios in Table 3 shows that unregistered firms are significantly more likely to issue a cov-lite loan than to issue a Rule 144a bond that they do not exchange ( $p$-value of 0.021 ). This result suggests that a cov-lite loan affords the unregistered issuer with additional advantages relative to a Rule 144a bond issue. An obvious advantage is that the Rule 144a bond is a security but the loan is not, so that borrowing in the form 
of a cov-lite loan does not subject an issuer to securities laws. In addition, however, the issuer of a cov-lite loan also benefits from bank screening.

The results in Table 3 suggest that cov-lite loans are particularly attractive for registered firms that deregister subsequently to borrowing. Many of these firms likely know that they may deregister at the time of issuing the debt. Among such firms, the relative risk ratio for cov-lite issuance is 11.27, significantly larger than the ratio of 4.35 for cov-heavy loans, 2.20 for never exchanged Rule 144a bonds, and 0.94 for exchanged Rule 144a bonds (all Wald test $p$-values are 0.000). This result is consistent with the existence of a group of firms that want to deregister and avoid being subject to the provisions of securities laws and the Trust Indenture Act while still issuing an instrument that resembles a bond. The advent of cov-lite loans allows them to do so. A concern with these results is that the deregistering firms might be mostly firms that go private through an LBO. In section 6.1, we show that our results are not affected if we use an indicator variable for firms associated with an LBO.

A few findings for the control variables are worth commenting on. First, loan issuers are younger than public bond issuers. To the extent that cov-lite loans are commonly accompanied by a monitored bank loan (Berlin, Nini, and Yu (2020)), this result is consistent with models that predict that younger firms may choose to issue monitored debt. Second, firms with very poor ratings are unlikely to issue either cov-lite or cov-heavy loans, but instead issue bonds. This result contrasts with the findings of Denis and Mihov (2004). The restrictions on banks from issuing loans to excessively risky firms during our sample period may help explain this result. The relative risk ratio for cov-lite (cov-heavy) issuance among issuers with a rating of $\mathrm{B}$ - is 0.30 (0.07). The relative risk ratios for loan issuance among issuers rated CCC+ or worse are close to zero, meaning that such loans are very rare. Compared to bonds, cov-lite loans are relatively more likely to be rated $\mathrm{BB}-, \mathrm{B}+$, or $\mathrm{B}$, and cov-heavy loans are relatively more likely to be rated BB-. Rule 144a bonds that are never exchanged appear to be issued by borrowers that are similar to issuers of public debt except in their registration status, while Rule 144a bonds that are subsequently exchanged appear to be issued by borrowers of lower credit quality than public bond issuers, and especially by borrowers with very poor credit ratings such as CCC+ or worse. 


\section{Credit spreads and liquidity differences between cov-lite loans and bonds}

The analysis thus far suggests that cov-lite loans are in many ways similar to speculative grade bonds: they do not have maintenance covenants, they are large, and they have long maturities, albeit about one year shorter than bonds. However, for cov-lite loans to be useful substitutes for bonds from the investors' perspective (H2), it is also important to assess whether the secondary market trading is as liquid for covlite loans as it is for bonds. Further, relatively high credit spreads for cov-lites compared to bonds or covheavy loans of similar risk would be evidence that would weaken the substitution hypothesis. Using our speculative debt sample, we discuss first credit spread differences and second liquidity differences. In the next section, we examine liquidity differences between cov-lite loans and cov-heavy loans in more detail using our leveraged loan sample.

Comparing credit spreads across bonds and loans is quite difficult for many reasons. Schwert (2019) studies the pricing differences between loans and bonds and finds that loans are especially expensive relative to bonds for safer loans in that credit spreads are similar even though loans are secured. He discusses many of the reasons why assessing credit spread differences is difficult for firms that have both publicly registered bonds and loans. The difficulties he encounters are magnified in our sample in such a way that the exercise he undertakes is impossible to conduct in our study. Our focus is on the importance of registration status and securities laws for the decision to raise funding through bonds versus loans. The approach used by Schwert (2019) requires Compustat data and, therefore, cannot be used for unregistered firms. As a result, our comparison of credit spreads is much more limited in purpose and more caveats apply than in the Schwert (2019) study. As discussed in Section 2, evidence of high credit spreads on cov-lites compared to bonds, accounting for observable differences in issuer and issuance characteristics, would be evidence casting doubt about the substitution hypothesis.

We obtain yield data for bonds from FISD. The difficulty with these data is that FISD has the coupon rate for $96 \%$ of bonds, but has the yield only for $60 \%$ of bonds. We therefore show results using the yield and results using the coupon rate. It turns out that for the bonds where we have both the coupon rate and 
the yield, the two are close to each other (the means are essentially the same). Bonds for which the yield is unavailable tend to have worse ratings and higher coupons. The second issue is that the bank loans have generally floating rate payments, so that they have a spread above LIBOR. In contrast, public debt generally has a fixed rate payment. To make the two debt instruments comparable, we compute the spread for the public bond as the bond yield minus the linearly interpolated rate for swapping a fixed rate interest into 3month LIBOR.

The two instruments can differ in the probability of default, in the expected loss given default, in early repayment likelihood, and in liquidity. As we discuss later, liquidity differences between bonds and covlite loans seem second-order. In general, callable debt will have a higher yield, but leveraged loans can be prepaid. Since the cov-lite debt would not be subject to the Trust Indenture Act, it is possible that it would be more easily renegotiated. Easier renegotiation would mean that the debt has a lower probability of default and lower loss given default than public debt, which again would imply a lower yield. Lastly, the loan is not subject to securities laws compared to a public bond or a bond issued under Rule 144a. The lack of these attributes would be expected to increase the credit spread of a loan assuming that investors find these attributes valuable. Any evidence that credit spreads of cov-lite loans are higher than those of public bonds or bonds issued under Rule 144a would be evidence that investors value attributes of securities laws more than they value the fact that cov-lite loans are secured. Such evidence would be inconsistent with the substitution hypothesis.

In Table 4, we compare the credit spreads of loans and senior bonds. Because we are interested in the spreads charged by institutional investors, we discard loans that do not have an institutional tranche and consider only the spread of a loan's first lien institutional tranche. We find that cov-lite loans have a lower yield than public bonds or bonds issued under Rule 144a when we control for firm age, deal size, deal maturity, industry, rating, and year-quarter effects. This evidence suggests that the cov-lite loans are safer for investors relative to bonds, so that investors value the fact that these loans are secured more than they value the benefits associated with the bonds because they are issued by SEC registrants and/or because they are securities. We find evidence that registration is associated with lower credit spreads for bonds and loans. 
However, when we allow for a different impact of registration on cov-lite loans and cov-heavy loans, we find that the lack of registration is not associated with a higher credit spread for cov-lite loans. If we restrict the sample to only firms with registered securities, so that Compustat data is available, we find again that cov-lite loans have a lower credit spread than bonds.

If a firm, everything else equal, issues a cov-heavy loan instead of a cov-lite loan, the cov-heavy loan should be safer than the cov-lite loan if the additional monitoring of cov-heavy loans is effective and hence should have a lower credit spread. However, this effect would be reduced if cov-heavy loans are less liquid than cov-lite loans as we show later. It would also be reduced to the extent that institutional investors are ill-equipped to monitor loans (see Berlin, Nini, and Yu, 2020) and to the extent that monitoring might have excessive coordination costs (see Becker and Ivashina, 2017). We find evidence that the credit spread on cov-heavy loans is higher than the credit spread on cov-lite loans for issuers for the whole sample. This difference is driven by unregistered borrowers. There is no difference for registered borrowers. Interestingly, for registered borrowers, controlling for variables available on Compustat has a similar impact on cov-heavy and cov-lite loan credit spreads. The evidence on the comparison of credit spreads for covheavy and cov-lite loans is consistent with adverse selection costs associated with bank monitoring and monitoring limitations for institutional investors. However, we cannot exclude that arrangers have information about a cov-heavy issuer that makes them unwilling to arrange a cov-lite loan for that issuer. In this case, the creditworthiness of the cov-heavy issuer would be worse for reasons we cannot observe. Irrespective of the explanation, the results support the legal status hypothesis.

Panel A of Table 4 distinguishes between Rule 144a bonds that are never exchanged and those that are subsequently exchanged. A Rule 144a bond that is never exchanged for a public bond shares some similarity with a cov-lite loan in that it allows the issuer to borrow without maintenance covenants and without SEC registration. However, it is still subject to securities laws. As stated in section 2, if the credit spread on such a Rule 144a bond were to be sufficiently low compared to a cov-lite loan, this would weaken support for the legal status hypothesis. Panel A of Table 4 shows to the contrary that Rule 144a bonds that are never exchanged have higher credit spreads than public bonds and, hence, than cov-lite loans. 
Several concerns arise with these regressions. First, since almost all public bonds are callable, we cannot control for callability. However, some bonds are callable at a fixed price while others have a makewhole provision. If we control for the type of callability, our results do not change. Second, we use the coupon spread instead of the yield because we are missing the yield for many bonds. If we restrict our sample to those issues for which we have both yield and coupon, our results are very similar. Third, some cov-lites are issued as part of a package as discussed earlier and the investors may benefit from this association (see Berlin, Nini, and Yu (2020)). However, when we add an indicator variable for whether the cov-lite is a stand-alone cov-lite, we find that the indicator variable has a negative significant coefficient. Lastly, we add firm fixed-effects. The result that unregistered cov-lite loans have a lower credit spread than unregistered cov-heavy loans continues to hold, but the economic magnitude of the difference is cut in half. This result suggests that the adverse selection advantage of cov-lites is potentially smaller when a firm has borrowed through a bond or a cov-heavy loan as well.

As stated above, a legitimate concern is that the difference in spreads between cov-lite loans and covheavy loans is driven by a selection effect. While this concern is difficult to address, in Table 5 we take a step towards the logic used by Schwert (2019) of comparing debt instruments by the same firm at the same point in time. Although we do not observe institutional cov-lite loans and institutional cov-heavy loans issued simultaneously by the same firm, in Column (1) of Panel A of Table 5, we match each institutional cov-lite loan with an institutional cov-heavy loan issued by the same firm in the same year. In the rare case in which more than one potential match is available, we choose the nearest neighbor in terms of deal size and maturity using the Mahalanobis distance. We find a match for only 22 cov-lite loans, for which the average treatment effect on the treated (ATET) is a statistically significant negative 84 basis points. To expand the comparison, in Column (2) we perform an exact match only on the issuer and find the nearest neighbor in terms of the launch date of the loan, but we restrict the sample to those matched pairs that are issued within the same or two adjacent calendar years instead of within the same year. Doing so expands the usable sample to 150 loan pairs, with an ATET of minus 73 basis points. Allowing (in the extreme) almost two years to pass between loans raises the question of whether the issuers' creditworthiness still 
remains the same. To address this concern, in Column (3) we additionally require an exact match on the firm's rating across both loans. Sample size is reduced by about $40 \%$, but the ATET remains virtually identical at minus 76 basis points.

Matching loans within firm is inherently difficult due to infrequent originations. In Panel B, we instead follow the approach of Ivashina and Sun (2011) and Nadauld and Weisbach (2012) and analyze how the within-deal difference in the credit spread of the institutional tranche vs. the bank revolving line of credit varies across deals that have either a cov-lite or cov-heavy institutional tranche. Since both the institutional tranche and the bank tranche are issued at the same time and have the same priority, the pricing of the bank tranche can be expected to reflect any omitted variables related to the riskiness of the firm's cash flows and/or the value of its collateral. Subtracting the credit spread paid on the bank tranche from the spread paid on the institutional tranche should thus purge the effect of such omitted firm fundamentals. Table 5 shows that we continue to find that cov-lite loans are cheaper than cov-heavy loans for unregistered firms, while credit spreads are statistically indistinguishable for registered firms. Compared with the results in Table 4, the effect is reduced from about 30 basis points to 13 basis points.

The evidence presented so far in this section supports the substitution hypothesis in that there is no evidence that investors charge a premium to hold cov-lite loans instead of bonds. Moreover, we find evidence that cov-lite loans trade at spreads that are lower than those at which bonds trade. Though we cannot value directly the impact on credit spreads of the fact that cov-lite loans are secured, we can get a sense of the benefit of loan collateral by considering the differences in recovery rates for bank loans and unsecured bonds. According to Moody’s, loss given default for bank loans (senior unsecured bonds) was 19.6\% (52.1\%) from $1987-2017 .{ }^{9}$ The average cov-lite loan in our sample is rated $\mathrm{B}+$ and has a maturity of six years. The probability of default for a B+ rated issuer over six years is $20.1 \%$ according to Moody's. The difference in credit spreads between bonds and bank loans should be at least large enough to compensate bondholders for the greater loss given default in a perfect markets risk-neutral world.

\footnotetext{
${ }^{9}$ Ultimate recovery rates are taken from Moody’s Investors Service Data Report (Ou et al., 2018).
} 
Therefore, assuming that Moody's estimate of the difference in loss given default is an appropriate measure of expected loss differences, the collateral justifies a difference in the credit spread of $0.325 \times 0.201 / 6=109$ basis points, which is very similar to the difference we find. This back-of-the-envelope calculation suggests that the value of collateral can explain the difference in spreads between cov-lite loans and bonds and that investors do not appear to charge a premium on loans to compensate for the fact that they are not securities.

We turn next to a comparison of liquidity between bonds and loans. It is difficult to compare directly the liquidity of loans versus bonds since there is no database that tracks actual trade prices for loans. However, the LSTA/Thomson Reuters Mark-to-Market Pricing Service provides market-maker quotes for the secondary loan market, which we can compare to quoted spreads in the bond pricing literature. We obtain average quoted spreads for bonds from Chen, Lesmond, and Wei (2007). We use the average bidask spreads they report for noncallable bonds of maturity between one and seven years from 1995 through 2003 (with most quotes available from 2000 onwards). This maturity range matches well with our sample since $94 \%$ of sample loans have a maturity between one and seven years.

We then match our loans to the bond results in Chen, Lesmond, and Wei (2007) based on the rating. We compute the average bid-ask spread for both cov-lite loans and cov-heavy loans over the first three months, and the first, second, and third year after the launch date of the loan. A breakdown of spreads based on years since issuance is not available for bonds. Notice that Chen, Lesmond, and Wei (2007) use up-todate bond ratings while our loan data is limited to at-issue ratings. To improve comparability, loans that are priced as distressed and likely would have been downgraded during the time period in question are excluded from the analysis. In Panel A of Table 6, we classify a loan as distressed if it trades below 90 cents per one dollar of principal. In Panel B, loans are excluded if they trade below 95 cents. Note that these conservative criteria may cause us to overstate the difference between cov-lite loans and bonds, if anything. For a loan with five years to maturity, a drop in price to 90 cents represents a change in yield approximately equivalent to a downgrade from straight BB to B- (priced at LIBOR plus 284 basis points and LIBOR plus 497 basis points, respectively, on average). A drop in price to 95 cents represents a change in yield about equal to a downgrade from straight BB to B+ (the latter being priced at LIBOR plus 387 basis points on average). 
Table 6 shows that quoted spreads are very similar for covenant-lite loans and bonds. For BB rated debt, bonds have a quoted spread of 54 basis points compared to 58 basis points for cov-lite loans. Covheavy loans trade at a wider spread of 70 basis points. For B rated debt, bonds trade at a spread of 59 basis points, compared to 63 basis points for cov-lite loans and 77 basis points for cov-heavy loans. Note that statistical significance tests cannot be performed for bonds vs. loans since we do not have the underlying data on bonds. However, in section 6, we verify that the difference in liquidity between cov-lite loans and cov-heavy loans is statistically significant.

Table 6 also suggests that loans become slightly less liquid in the secondary loan market over time. This effect is more pronounced for B rated loans than BB rated loans. A comparison of Panels A and B suggests that a significant portion of the increase in average spreads over time is due to some loans deteriorating in credit quality rather than an actual widening of spreads for a given credit quality. For example, the median loan has a maturity of six years. If such a loan trades below 95 cents in its third year, this would represent a significant increase in its yield, which would likely be accompanied by a downgrade. When we exclude loans trading below 95 cents, spreads for loans with an at-issue rating of BB do not widen over time and spreads for B rated cov-lite loans widen only by five basis points from the first three months through year 3.

\section{Cov-lite loans versus cov-heavy loans}

We now turn to comparing cov-lite loans with cov-heavy loans in more detail. Such a comparison will allow us to evaluate the substitution hypothesis, which predicts that cov-lite loans are better substitutes for bonds than cov-heavy loans. Because a richer set of variables is available for leveraged loans than for bonds, this allows us to establish that cov-lite loans are substitutes for bonds in ways that cov-heavy loans are not. In addition, this analysis allows us to assess how the differences in information asymmetries between banks

and investors are related to differences in liquidity between cov-lite loans and cov-heavy loans. We would expect banks to have more of an information advantage for non-registered firms than for registered firms, 
as many registered firms are publicly listed firms and as registered firms file regularly with the SEC. Hence, the difference in liquidity due to the difference in adverse selection should be stronger for loans issued by non-registered firms.

Our leveraged loan sample includes all US leveraged loans from LCD from January 2005 through April 2015. Unlike the speculative grade debt sample, the leveraged loan sample consists of all loans found in LCD, including those that do not have a rating. This allows for a more accurate comparison between covlite loans and the full set of cov-heavy loans. In the first part of the section, we consider the decision to issue a cov-lite loan instead of a cov-heavy loan. In the second part, we compare the liquidity of cov-lite loans to the liquidity of cov-heavy loans.

\subsection{The decision to issue a cov-lite loan instead of a cov-heavy loan}

Table 7 shows univariate tests of differences between cov-lite and cov-heavy loans. Cov-lite loans are \$310 million dollars larger, on average, than cov-heavy loans. Although some cov-heavy loans are large so that mean deal size is around \$548 million, the median deal size of \$302 million is smaller than the median deal size reported for bonds in Table 1 . The maturity of cov-lite loans is about one year longer than the maturity of cov-heavy loans. Consistent with the substitution hypothesis, 96\% of cov-lite loans are rated, while only $65 \%$ of cov-heavy loans are rated. In further support of the substitution hypothesis, we find that $90 \%$ of cov-lite loans trade on the secondary market compared to $44 \%$ of cov-heavy loans.

Among traded loans, various indicators suggest that cov-lite loans are significantly more liquid. Timeto-break, which is the time from loan launch to the time the loan starts trading (referred to as the "break date” in industry parlance) is only 14 days for cov-lite loans compared to 20 days for cov-heavy loans. Covheavy loans are more than twice as likely to break into trading at a price below 99 cents on one dollar of principal. Because these instruments are floating rate and time-to-break is less than two months for $99 \%$ of sample loans, a low break price cannot be caused by changes in LIBOR and is unlikely to be caused by a 
change in borrower creditworthiness between loan launch and break date. Thus, a low break price is consistent with a liquidity discount.

We track secondary market loan trading volumes for loan participation mutual funds using the CRSP Mutual Funds database. In the average month, loan participation funds trade $1.4 \%$ of a cov-lite loan's principal compared to $0.9 \%$ for cov-heavy loans. We observe at least one trade for $60 \%$ of all calendar months for the average cov-lite loan compared to $41 \%$ for cov-heavy loans. Data from the LSTA/Thomson Reuters Mark-to-Market Pricing Service suggest that cov-lite loans have lower bid-ask spreads and attract more quotes from brokers.

We note that having more loan participation funds holding shares of a cov-lite loan could reflect that they prefer loans that are easily tradable, but it could also be that the presence of loan participation funds in the lending syndicate causes the loan to be structured as cov-lite because such loans have lower coordination costs (Becker and Ivashina (2017)). To account for this possibility, we collect the number of loan participation funds that initially report holding shares in the loan when it breaks into secondary market trading. We use this variable as a proxy for differences that may be due to coordination cost considerations. The average cov-lite loan has five loan participation funds in the syndicate, compared to two funds for the average cov-heavy loan.

We also report differences in a variety of other loan and firm characteristics. Cov-lite loans are more likely to be used in deals sponsored by private equity firms, especially the initial LBO financing, they are less likely to include bank tranches such as revolvers or term loans A, and are more likely to include a second lien facility and be structured as asset based loans, which tend to be heavily collateralized typically by inventory and/or accounts receivable. Cov-lite loans are much less common among small firms, whether measured by firms' total assets or by LCD’s middle market indicator. Even for this revised sample that includes unrated loans, cov-lite loans are more common among unregistered and deregistering firms and cov-lite issuers are older. Consistent with asset based lending practices, cov-lite loans are issued by firms with higher current ratios, but these firms also have higher pre-existing leverage and lower property, plant and equipment than cov-heavy issuers. 
In Table 8, we investigate the role of SEC registration for the decision to issue a cov-lite loan instead of a cov-heavy loan. With the legal status hypothesis, firms issue cov-lite loans as substitutes for bonds to avoid SEC registration. In contrast, cov-heavy loans are not substitutes for bonds, and firms do not issue them to avoid SEC registration that would occur if they issued bonds. Columns (1) through (3) focus on firms that are registered with the SEC at the time of loan issuance and assesses whether cov-lite issuers are more likely to subsequently deregister. The results show that they are. Average marginal effects for covlite loans are positive and statistically significant throughout, with the vast majority of the additional deregistrations taking place during the first year after loan issuance. The average marginal effect of covlite issuance on being deregistered after three years is a 5.8 percentage point increase in the probability of being deregistered after three years, compared to a $10.8 \%$ baseline probability. Note that these deregistrations are voluntary deregistrations. Firms that disappear due to bankruptcy or a merger are not coded as deregistrations. Larger deals with longer maturities are marginally less likely to result in deregistration, while sponsored deals, and particularly LBOs are more likely to result in deregistration. Table 8 also includes an interaction between the LBO indicator and the cov-lite indicator to allow for the possibility that deregistration following cov-lite issuance might be driven by LBOs. We do not find any evidence in favor of this explanation.

An important result in Table 8 is that bond refinancings are positively associated with deregistration. If firms were to substitute loans for bonds to benefit from bank monitoring, they would use cov-heavy loans to refinance bonds. Instead, in column (4) we see that they are more likely to use a cov-lite loan for a bond refinancing. Refinancing a bond with a cov-lite loan is especially advantageous for a firm that plans to deregister since the major difference between a cov-lite loan and a bond is that the bond requires SEC registration and the loan does not, so having an outstanding bond would be an obstacle to deregistering but an outstanding loan would not be. We see that firms that use a cov-lite loan to refinance a bond are more likely to deregister immediately.

Column (4) of Table 8 reports average marginal effects from a probit regression of cov-lite issuance on an unregistered firm indicator, a deregistering firm indicator, and control variables. Due to the lack of cov- 
lite issuance during the GFC, perfect predictability precludes the use of time fixed effects in a probit regression. ${ }^{10}$ To remedy this issue, we calculate the prevailing percentage of cov-lite loans at the time of loan issuance, which corresponds to the percentage of loans issued over the past 60 days that are cov-lite loans. This variable very strongly predicts cov-lite issuance, which is supportive of the Diamond, Hu, and Rajan (2019) model. At the margin, a 1\% increase in the prevailing percentage of cov-lite loans is associated with a $0.7 \%$ increase in the probability that the current loan is cov-lite. We also include the net percentage of senior loan officers that report a tightening of credit standards in the previous quarterly Fed loan officer survey, although this variable does not capture any additional information beyond that contained in prevailing cov-lite issuance. Column (4) of Table 8 shows that both unregistered and deregistering firms are more likely to take out cov-lite loans than cov-heavy loans. On average, being unregistered increases the probability of cov-lite issuance by 2.6 percentage points and being a deregistering firm increases the probability of cov-lite issuance by 5.7 percentage points relative to a baseline probability of $17.7 \%$. Findings for control variables remain similar to those noted in Table 7, except that the sign on second lien facilities turns negative, likely because $95 \%$ of second lien facilities accompanied by a cov-lite loan are sponsored by a private equity firm. Consistent with the legal status hypothesis, when firms use a loan to refinance a bond, this loan is 4.3 percentage points more likely to be cov-lite.

\subsection{Comparison of the liquidity of cov-lite loans and of cov-heavy loans}

We now discuss the liquidity of cov-lite loans compared to cov-heavy loans. In Table 9, we ask whether cov-lite loans are more likely to be traded on the secondary loan market. We consider a loan to be traded if LCD reports a break price. Regardless of whether we consider all firms, only rated firms, or only registered firms with all financial data available in Compustat or Capital IQ, we find that cov-lite loans are significantly more likely to be traded. Using all loans, cov-lite loans are associated with a 15.9 percentage point increase in the probability of trading on the secondary market compared to a baseline probability of

\footnotetext{
${ }^{10}$ This problem does not apply to the multinomial logit in Table 3 since we do observe both bond issuances and covheavy issuances during the GFC.
} 
$52 \%$. The marginal effects in column (2) suggest that cov-lite loans are as likely to trade for registered firms as they are for unregistered firms since the sum of the effects for registered plus the interaction of registered with cov-lite is indistinguishable from zero (Wald test $p$-value for probit coefficients of 0.256 ). The negative effect for registered firms suggests that cov-heavy loans of registered firms are even less likely to trade than cov-heavy loans of unregistered firms.

Next, we ask whether cov-lite loans break into secondary market trading more quickly. In Table 10, the dependent variable is time-to-break. As Table 10 shows, the average cov-lite loan breaks into trading one day earlier. This difference is significant although the economic magnitude is smaller than in the univariate tests reported in Table 7. In an unreported regression, we find that the reason appears to be the addition of year fixed effects, without which the difference is five days. Hence, time-to-break has become faster for all loans, but is especially fast for cov-lite loans. Table 10 reveals an interesting difference between cov-lite loans of registered issuers and those of unregistered issuers. Compared to cov-heavy loans, time-to-break is two days faster for cov-lite loans of unregistered issuers, but not faster for cov-lite loans of registered issuers. This finding appears consistent with theories pointing to a lower adverse selection problem of covlite loans compared to cov-heavy loans (Ayotte and Bolton (2011), Parlour and Plantin (2008)) as any potential information advantage of the initial lenders may be greater for unregistered issuers.

In Table 11, we examine break prices reported by LCD. The break price represents the first price at which the loan starts trading in the secondary market. As discussed earlier, break prices can be used as a measure of liquidity so long as the instrument is floating rate and differences in break prices are not due to changes in creditworthiness before the loan breaks into trading. Table 11 shows that cov-lite loans break into trading at a price that is 0.24 cents higher per dollar of principal than cov-heavy loans. To further alleviate concerns about changes in creditworthiness, in an unreported regression, we exclude the $8 \%$ of loans with time-to-break of more than 30 days. We continue to find a difference of 0.23 cents.

Columns (6) through (10) report marginal effects from probit regressions of whether or not a loan breaks into trading below a price of 99 cents, which represents the $10^{\text {th }}$ percentile of the break price distribution. Cov-lite loans are $8.2 \%$ less likely to have a low break price than cov-heavy loans. The 
interactions of the cov-lite loan indicator with the registered indicator again suggest that the liquidity advantage of cov-lite loans over cov-heavy loans is stronger for unregistered issuers than for registered issuers, although the difference in break price between the two types of loans for registered issuers is still significant.

Tables 8 through 10 only assess whether cov-lite loans are more liquid immediately after loan origination, but do not make it possible to make statements about liquidity over the entire life of the loan. In Table 12, we use data from the CRSP Mutual Funds database to test whether covenant-lite loans trade more frequently than covenant-heavy loans. Data availability starts in June 30, 2010 and our download tracks loan trading until August 31, 2016. Loans originated prior to June 30, 2010 are excluded from this analysis.

We find that cov-lite loans are indeed traded more frequently. In Panel A, we calculate trading volume as the monthly absolute change in the holdings of principal each loan participation fund reports for a given loan. The average monthly percentage of total principal traded among loan participation funds is $0.3 \%$ higher for cov-lite loans than for cov-heavy loans, a large difference compared to the sample mean of 1.1\%. We also find that there are 5\% more months in which loan participation funds report at least one trade for a cov-lite loan than at least one trade for a cov-heavy loan. The average loan has at least one trade in $49 \%$ of all months between the first and last month that CRSP reports at least one fund holding shares in the loan. As before, the liquidity advantage appears stronger for cov-lite loans of unregistered firms. The interaction between the cov-lite indicator and the registered firm indicator is negative and significant both in columns (2) and (7). In a Wald test for column (2), the liquidity advantage of cov-lite loans continues to be strongly significant even among registered issuers with a $p$-value of 0.000 .

One problem with tracking trades using the absolute change is that we double count trades in which a loan participation fund acts as buyer and another fund acts as seller. To remedy this issue, Panel B only looks at purchases of principal as evidenced by an increase in the loan shares held. We continue to find that cov-lite loans are more liquid, and the difference continues to be larger for unregistered issuers. 
In our last test, we use quote data from the Thomson Reuters/LSTA Mark-to-market Pricing Service to examine loan liquidity. Because these data are available to us starting in January 2010, the sample includes only those loans that were originated between January 2010 and April 2015. Panel A uses quoted bid-ask spreads as a measure of liquidity and Panel B uses the number of brokers providing quotes. One problem with measuring secondary market quotes for loans is that distressed loans have dramatically wider bid-ask spreads than non-distressed loans. There are also fewer brokers willing to provide quotes for such loans. Therefore, we control for the average bid-ask midpoint during the time period that the regression examines in each regression in Table 13. In addition, in columns (5) through (8), we exclude distressed loans, defined as loans with an average bid-ask midpoint below 90 cents per one dollar of principal. Panel A shows that covenant-lite loans have tighter bid-ask spreads than covenant-heavy loans. During the first three months of a loan's life, cov-lite loans of unregistered issuers have a four basis points tighter spread than cov-heavy loans of such issuers. The sample average spread is 74 basis points. By contrast, for registered issuers the bid-ask spreads of cov-lite loans and cov-heavy loans do not differ significantly, consistent with market makers having fewer concerns about adverse selection when SEC filings provide public information about the firm. Importantly, while the number of loan participation funds in the syndicate is positively associated with cov-lite issuance (see Table 7), it is not associated with tighter bid-ask spreads immediately after loan origination. This result suggests that the coordination cost motive of cov-lite issuance and liquidity effects are distinct from one another.

The longer we follow a loan, the more likely it is that the borrower's creditworthiness will change, so that an increasing fraction of loans will be priced as distressed. When including distressed loans, the liquidity advantage for cov-lite loans disappears after the first year. However, this is due to cov-lite loans facing a greater likelihood of being priced as distressed at some point during the loan's life. ${ }^{11}$ Once we

\footnotetext{
${ }^{11}$ Cov-heavy loans are more likely to be repriced following adverse developments for the borrower, which means that they are also more likely to trade close to par after such developments. Due to the lack of financial maintenance covenants, it is much more difficult for lenders to initiate renegotiation of cov-lite loans when the borrower's performance deteriorates. By contrast, a cov-heavy loan can be renegotiated to allow for an increase in the interest rate. If the interest rate is increased so that it again reflects the borrower's current creditworthiness, then the price of the loan should increase such that it again approaches one dollar per dollar of principal.
} 
exclude distressed loans, cov-lite loans have consistently lower bid-ask spreads than cov-heavy loans throughout years 2 and 3 as well.

In Panel B, we analyze the number of quotes as a measure of market depth. Again, cov-lite loans attract more brokers than cov-heavy loans. Compared to a cov-heavy loan, a cov-lite loan has about a 20\% probability of attracting a quote by one additional broker. The sample median loan has quotes from two brokers, with an average of 2.5. However, the pattern for the number of quotes does not perfectly match the pattern for bid-ask spreads. During the first year, unregistered issuers have more quotes for their cov-lite loans than their cov-heavy loans. However, in years 2 and 3, the difference is driven by registered issuers, which in general are covered by more brokers. Yet this pattern in market depth does not seem to affect the actual quotes provided as shown in Panel A.

Overall, the results in this section are consistent with both the legal status and the substitution hypotheses introduced in Section 2. Unregistered issuers and those about to deregister are more likely to use cov-lite loans conditional on the credit rating of the issuer. Cov-lite loans are better substitutes for bonds than cov-heavy loans in that they are much more likely to be rated, much more likely to be traded on the secondary market, and all of our secondary market liquidity measures indicate that traded cov-lite loans are more liquid than traded cov-heavy loans. In addition, the fact that much of the liquidity difference is driven by unregistered issuers about whom information is much harder to obtain is consistent with an adverse selection explanation for the difference in liquidity between cov-lite loans and cov-heavy loans.

\section{Conclusion}

Cov-lite loans share an important characteristic with bonds that other loans do not have in that they include incurrence covenants, but no maintenance covenants. In this paper, we examine whether firms use cov-lite loans as substitutes for bonds to avoid costs associated with having SEC registered securities. Compared to bond issuers as well as cov-heavy loan issuers, cov-lite loan issuers are less likely to be 
registered with the SEC and, if currently registered, much more likely to subsequently deregister. Firms that refinance a bond with a loan do so using a cov-lite loan.

Though comparisons of credit spreads are difficult when issuers include private firms, we find that covlite loans have lower credit spreads than bonds and, for private issuers, lower credit spreads than cov-heavy loans. This evidence on spreads is supportive of our hypotheses. The bond/cov-lite spread comparison is consistent with the substitution hypothesis. The cov-lite/cov-heavy comparison is supportive of the legal status hypothesis since, if the comparison went the other way, cov-heavy loans would likely be more attractive for some firms seeking to avoid registration than cov-lite loans. One way to interpret the bond/cov-lite comparison is that institutional investors appear to place a higher value on the fact that loans are secured than on the benefits of securities laws that accrue to bond holders. In fact, indirect evidence suggests that the spread difference can be wholly explained by the fact that cov-lite loans are secured and bonds are not. The evidence also suggests that investors do not value highly the control rights associated with cov-heavy loans, consistent with coordination costs rendering these control rights ineffective and/or institutional investors benefitting from a debt structure in which a bank still holds another loan that does have maintenance covenants.

We find that cov-lite loans are similarly tradeable compared to bonds. Like bonds, cov-lite loans are almost always rated. Quoted bid-ask spreads for cov-lite loans, but not cov-heavy loans, are similar to those reported in the literature for bonds. Various additional measures of secondary market liquidity suggest that cov-lite loans are significantly more liquid than cov-heavy bonds. The liquidity advantage of cov-lite loans is larger for unregistered issuers, consistent with financial covenants creating an adverse selection problem in secondary market trading.

Taken together, our results are consistent with the hypothesis that legal status is an important factor in the decision to borrow by entering a cov-lite loan rather than a bond and that it is an important driver for the growth in cov-lite loans among leveraged borrowers. They are also consistent with the hypothesis that bonds and cov-lite loans are priced and trade in similar ways, so that they are substitutes for some investors. 


\section{Appendix A. Variable definitions}

\begin{tabular}{|c|c|c|}
\hline Variable & Definition & Source \\
\hline \multicolumn{3}{|c|}{ Deal characteristics (loans and bonds) } \\
\hline Deal size & $\begin{array}{l}\text { Total deal amount combining all tranches of a } \\
\text { deal, expressed in } 2014 \text { US dollars }\end{array}$ & $\begin{array}{l}\text { LCD, Mergent FISD, Bureau } \\
\text { of Labor Statistics }\end{array}$ \\
\hline Maturity & Maturity of the debt expressed in years & LCD, Mergent FISD \\
\hline Senior & $\begin{array}{l}\text { Indicator equals one if the debt is senior, zero } \\
\text { otherwise }\end{array}$ & LCD, Mergent FISD \\
\hline Rating & $\begin{array}{l}\text { Loans: First lien bank loan rating from S\&P. } \\
\text { Moody's rating substituted where not } \\
\text { available. Corporate issuer rating substituted if } \\
\text { no first lien rating available. } \\
\text { Bonds: At-issue corporate issuer rating from } \\
\text { S\&P. Moody's rating substituted if } \\
\text { unavailable. Fitch rating substituted if neither } \\
\text { S\&P nor Moody's available. } \\
\text { Rating values: } 0 \text { indicates no rating. } 1 \text { indicates } \\
\text { a rating of BBB- or better. } 2 \text {, 3, } 4 \text {, etc. indicate } \\
\text { ratings of BB+, BB, BB-, etc. Ratings of CCC+ } \\
\text { or worse have a value of } 8 \text {. }\end{array}$ & LCD, Mergent FISD \\
\hline Yield spread & $\begin{array}{l}\text { Loans: Interest rate spread over LIBOR for the } \\
\text { first lien institutional tranche. } \\
\text { Bonds: Bond yield minus linearly interpolated } \\
\text { cost to swap fixed rate interest payment into 3- } \\
\text { month LIBOR. }\end{array}$ & $\begin{array}{l}\text { LCD, Mergent FISD, St. } \\
\text { Louis FRED }\end{array}$ \\
\hline Coupon spread & $\begin{array}{l}\text { Loans: Interest rate spread over LIBOR for the } \\
\text { first lien institutional tranche. } \\
\text { Bonds: Bond coupon rate minus linearly } \\
\text { interpolated cost to swap fixed rate interest } \\
\text { payment into 3-month LIBOR. }\end{array}$ & $\begin{array}{l}\text { LCD, Mergent FISD, St. } \\
\text { Louis FRED }\end{array}$ \\
\hline \multicolumn{3}{|c|}{ Loan characteristics (not available for/applicable to bonds) } \\
\hline Rated & $\begin{array}{l}\text { Indicator equals one if the issuer has a rating, } \\
\text { zero otherwise }\end{array}$ & LCD \\
\hline $\begin{array}{l}\text { Traded on secondary } \\
\text { market }\end{array}$ & $\begin{array}{l}\text { Indicator equals one if the issue has a break } \\
\text { price }\end{array}$ & LCD \\
\hline Time-to-break & $\begin{array}{l}\text { Days elapsed between break date and loan } \\
\text { launch date }\end{array}$ & LCD \\
\hline Break price & $\begin{array}{l}\text { Price at which loan breaks into trading on the } \\
\text { secondary loan market }\end{array}$ & LCD \\
\hline
\end{tabular}


Break below 99

Initial \# LP Funds

Average \% principal traded

\% months with trade

Bid-ask spread

Number of quotes

Sponsored

LBO

Bond refinancing

Revolver

Term loan A

Second lien facility

Asset based loan

Middle market
Indicator equals one if the break price is less LCD than 99 cents on the dollar, zero otherwise

Number of loan participation funds that report holding shares of a loan within one month of the break date. Set to zero if no loan participation funds report holding shares.

Average monthly percentage of the loan's principal traded by loan participation mutual funds.

Percentage of months in which at least one loan participation mutual fund reports a change in the number of loan shares it holds

Average over a given period of the difference between the secondary market ask quote and bid quote for a loan divided by the ask quote and multiplied by 100

Average over a given period of the number of brokers providing quotes for a loan in the secondary market

CRSP Mutual Funds database

CRSP Mutual Funds database

CRSP Mutual Funds database

Thomson Reuters/LSTA Mark-to-Market pricing service

Thomson Reuters/LSTA Mark-to-Market pricing service

LCD

Indicator equals one if the loan is sponsored by a private equity firm. Includes initial LBO loans and refinancings.

Indicator equals one if the purpose of the loan

LCD is to finance a leveraged buyout. LBO loans are a subset of sponsored loans.

Indicator equals one if the purpose of the loan LCD is to refinance a bond.

Indicator equals one if the loan contains a LCD revolving line of credit.

Indicator equals one if the loan contains a term LCD loan A.

Indicator equals one if the loan contains a LCD second lien facility

Indicator equals one if the loan is flagged as an LCD asset based loan by LCD.

Indicator equals one if LCD identifies the loan LCD as a middle market loan. LCD states that loans 
are considered part of the middle market if the issuer has less than \$50 million in EBITDA.

\section{Firm characteristics}

Unregistered firm

Deregistering firm

Firm age

Assets

Leverage

Current ratio

Tangibility
No asset data available for the fiscal year prior to debt issuance in either Compustat or Capital IQ. In the case of bond issuance, asset data also cannot be available three years prior to the last fiscal year since availability of such data is likely to be caused by the registration of the bonds themselves.

Asset data is available for the fiscal year prior to debt issuance, but ceases to be available within three years after debt issuance.

Year of debt issuance minus year the firm was founded. In the case of new legal entities created as a result of a spin-off, asset sale, or merger, the year the predecessor was founded is used.

Total book assets in \$ millions expressed in 2014 US dollars.

Long-term debt plus debt in current liabilities divided by total assets.

Current assets divided by current liabilities.

Net property, plant and equipment divided by Compustat, Capital IQ total assets.
Compustat, Capital IQ

Compustat, Capital IQ

Capital IQ, Google searches

Compustat, Capital IQ, Bureau of Labor Statistics

Compustat, Capital IQ

Compustat, Capital IQ

The following variables are winsorized at the $1^{\text {st }}$ and $99^{\text {th }}$ percentile: maturity, leverage, current ratio, coverage ratio, and tangibility. 


\section{References}

Ayotte, Kenneth, and Patrick Bolton, 2011, Covenant lite lending, liquidity, and standardization of financial contracts, in: Research Handbook on the Economics of Property Law, Kenneth Ayotte and Henry E. Smith (eds.), Edward Elgar, Cheltenham, UK.

Becker, Bo, and Victoria Ivashina, 2014, Cyclicality of credit supply: Firm level evidence, Journal of Monetary Economics 62, 76-93.

Becker, Bo, and Victoria Ivashina, 2017, Covenant-light contracts and creditor coordination, unpublished working paper.

Benmelech, Efraim, Nitish Kumar, and Raghuram Rajan, 2020, The decline of secured debt, unpublished working paper.

Berlin, Mitchell, and Jan Loeys, 1988, Bond covenants and delegated monitoring, Journal of Finance 43, 397-412.

Berlin, Mitchell, and Loretta J. Mester, 1992, Debt covenants and renegotiation, Journal of Financial Intermediation 2, 95-235.

Berlin, Mitchell, Gregory Nini, and Edison G. Yu, 2020, Concentration of control rights in leveraged loan syndicates,Journal of Financial Economics 137, 24-271.

Billett, Matthew T., Redouane Elkamhi, Latchezar Popov, and Raunaq S. Pungaliya, 2016. Bank skin in the game and loan contract design: Evidence from covenant-lite loans, Journal of Financial and Quantitative Analysis 51, 839-873.

Billett, Matthew T., Tao-Hsien Dolly King, and David C. Mauer, 2007, Growth opportunities and the choice of leverage, debt maturity, and covenants, Journal of Finance 62, 697-730.

Bolton, Patrick, and Xavier Freixas, 2000, Equity, bonds, and bank debt: Capital structure and financial market equilibrium under asymmetric information, Journal of Political Economy 108, 324-351.

Chava, Sudheer, and Michael Roberts, 2008. How does financing impact investment? The role of debt covenants, Journal of Finance 63, 2085 - 2121.

Chemmanur, Thomas J., and Paolo Fulghieri, 1994, Reputation, renegotiation, and the choice between bank loans and publicly traded debt, Review of Financial Studies 7, 475-506.

Chen, Long, David A. Lesmond, and Jason Wei, 2007, Corporate yield spreads and bond liquidity, Journal of Finance 62, 119-149.

Chernenko, Sergey, Isil Erel, and Robert Prilmeier, 2018, Nonbank lending, unpublished working paper.

Dang, Tri Vi, Gary B. Gorton, Bengt R. Holmstrom, 2019, The information view of financial crises,Annual Review of Financial Economics, forthcoming.

De Fontenay, Elisabeth, 2014, Do the securities laws matter? The rise of the leveraged loan market, Journal of Corporation Law 39, 725-768. 
Denis, David J., and Vassil T. Mihov, The choice among bank debt, non-bank private debt and public debt: evidence from new corporate borrowings, Journal of Financial Economics 70, 3-28.

Diamond, Douglas W., 1984, Financial intermediation and delegated monitoring, Review of Economic Studies 51, 393-414.

Diamond, Douglas W., 1991, Monitoring and reputation: The choice between bank loans and directly placed debt, Journal of Political Economy 99, 689-721.

Diamond, Douglas W., Hunzhi Hu, and Raghuram G. Rajan, 2019, Pledgeability, industry liquidity, and financing cycles, Journal of Finance, forthcoming.

Doidge, Craig, Andrew G. Karolyi, and René M. Stulz, 2013, The US left behind? Financial globalization and the rise of IPOs outside the US, Journal of Financial Economics 110, 546-573.

Doidge, Craig, Andrew G. Karolyi, and René M. Stulz, 2017, The U.S. listing gap, Journal of Financial Economics 123, 464-487.

Erel, Isil, Brandon Julio, Woojin Kim, Michael S. Weisbach, 2012, Macroeconomic conditions and capital raising, Review of Financial Studies 25, 341-376.

Fama, Eugene, 1985, What’s different about banks?, Journal of Monetary Economics 15, 29-39.

Fenn, George W., 2000, Speed of issuance and adequacy of disclosure in the 144A high-yield debt market, Journal of Financial Economics 56, 383-405.

Gao, Xiaohui, Jay R. Ritter, and Zhongyan Zhu, 2013. Where have all the IPOs gone?, Journal of Financial and Quantitative Analysis 48, 1663-1692.

Glushkov, Denys, Ajay Khorana, P. Raghavendra Rau, and Jingxuan Zhang, 2018, Why do firms go public through debt instead of equity?, Critical Finance Review 7, 85-110.

Gorton, Gary, and George Pennacchi, 1990, Financial Intermediaries and Liquidity Creation, Journal of Finance 45, pp. 49-71.

Huang, Rongbing, and Gabriel G. Ramirez, 2010. Speed of issuance, lender specialization, and the rise of the 144A debt market, Financial Management 39, 643-673.

IMF, 2020, Global financial stability report, April.

Ivashina, Victoria, and Zheng Sun, 2011, Institutional demand pressure and the cost of corporate loans, Journal of Financial Economics 99, 500-522.

Murfin, Justin, 2012, The supply-side determinants of loan contract strictness, Journal of Finance 67, 15651601.

Nadauld, Taylor D., and Michael S. Weisbach, 2012, Did securitization affect the cost of corporate debt? Journal of Financial Economics 105, 332-352.

Nini, Greg, David C. Smith, and Amir Sufi, 2012, Creditor control rights, corporate governance, and firm value, Review of Financial Studies 25, 1713-1761. 
Ou, Sharon, Sumair Irfan, Yang Liu, Joyce Jiang, and Kumar Kanthan, 2018, Annual Default Study: Corporate Default and Recovery Rates, 1920-2017, Moody's Investors Service Data Report.

Parlour, Christine, and Guillaume Plantin, 2008, Loan sales and relationship banking, Journal of Finance 63, 1291-1314.

Prilmeier, Robert, 2017, Why do loans contain covenants? Evidence from lending relationships, Journal of Financial Economics 123, 558-579.

Rajan, Raghuram, 1992, Insiders and outsiders: The choice between informed and arm's-length debt, Journal of Finance 47, 1367-1400.

Rajan, Raghuram, and Andrew Winton, 1995, Covenants and collateral as incentives to monitor, Journal of Finance 60, 1113-1146.

Rauh, Joshua D., and Amir Sufi, 2010, Capital structure and debt structure, Review of Financial Studies 23, 4242-4280.

Roberts, Michael, 2015, The role of dynamic renegotiation and asymmetric information in financial contracting, Journal of Financial Economics 116, 61-81.

Roberts, Michael, and Amir Sufi, 2009, Renegotiation of financial contracts: Evidence from the introduction of bank loan ratings, Journal of Finance 64, 1657-1695.

Schwert, Michael, 2019, Does borrowing from banks cost more than borrowing from the market?, Journal of Finance, forthcoming.

Saveendra, Daniel, 2018. Syndicate size and the choice of covenants in debt contracts, Accounting Review, forthcoming. 


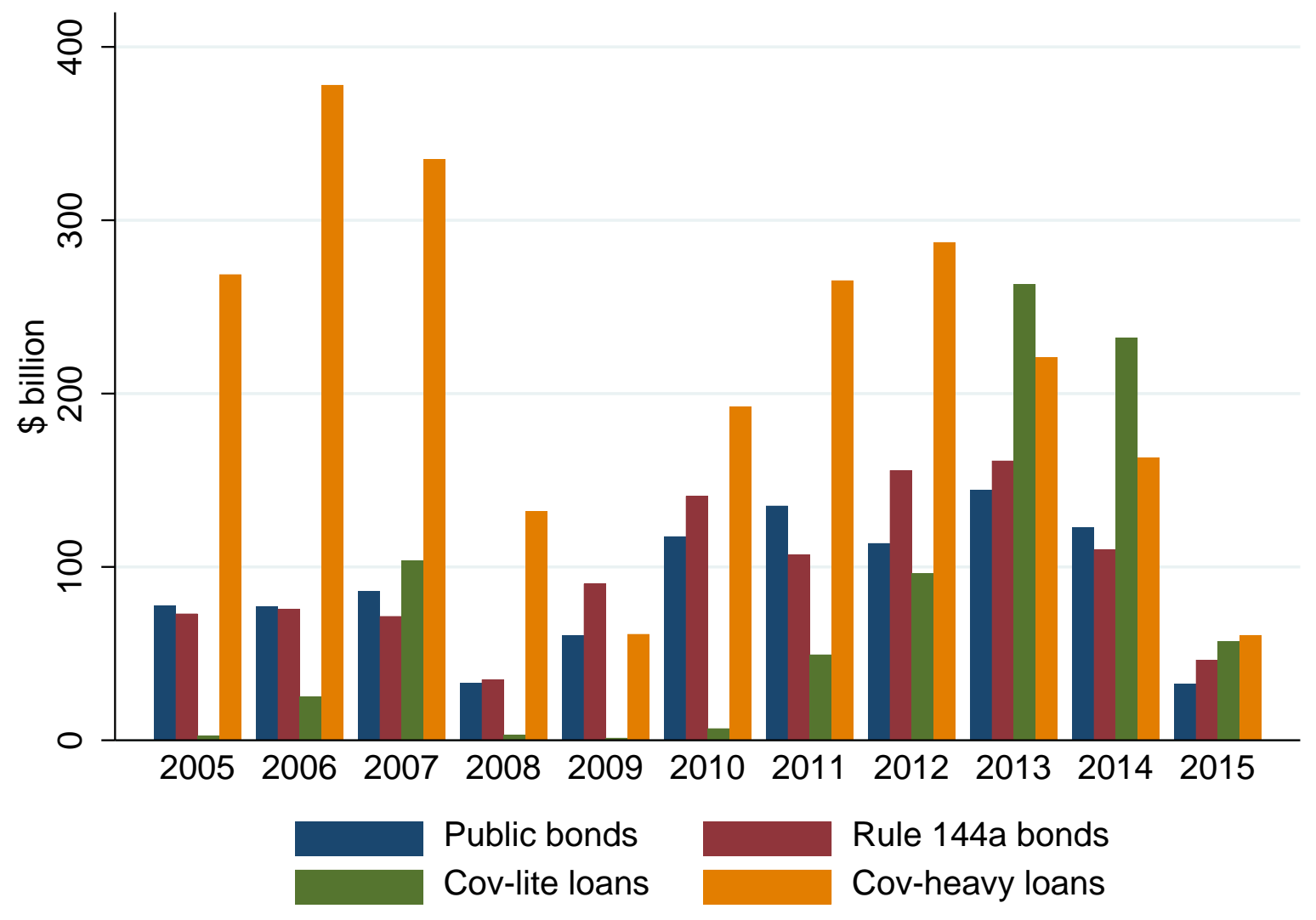

Figure 1: Total new money raised by speculative grade borrowers

This figure shows the total amount of new money raised each year by non-financial, non-utility speculative grade US issuers on the US leveraged loan market and the US public and Rule 144a bond markets. Loan data are from Capital IQ LCD and bond data are from Mergent FISD. A loan is defined as covenant-lite if it contains a covenant-lite facility, even if other facilities are present. Because $30 \%$ of borrowers on the leveraged loan market are unrated, issue volume for loans includes unrated issuers. The average loan by an unrated issuer has a spread of 378 basis points (the median is 350 basis points), comparable to the average loan of a B+ rated issuer (the mean spread is 387 basis points and the median is 375 basis points). Data for 2015 end on April 30, 2015 and the sample is limited to deals that LCD reported as completed as of May 12, 2015. 


\section{Table 1: Univariate differences between borrowers of covenant-lite loans and bond issuers}

This table shows summary statistics for covenant-lite loans, public bonds, and Rule 144a bonds, respectively, as well as the results from $t$-tests for differences between covenant-lite loans and the two types of bonds. The covenant-lite sample includes covenant-lite loans issued by US issuers on the US leveraged loan market from January 1, 2005 through April 30, 2015. Loan data are from Capital IQ LCD, and the sample is limited to deals that LCD reported as completed as of May 12, 2015. A loan is defined as covenant-lite if it contains a covenant-lite facility, even if other facilities are present. The bond sample includes bonds issued by US corporate issuers from January 1, 2005 through April 30, 2015, taken from Mergent FISD. The bond sample excludes private placements, foreign currency bonds, global offerings, convertible, putable, and exchangeable bonds. Because the sample contains almost no covenant-lite loans rated better than $\mathrm{BB}+$, to keep the two samples comparable only debt instruments rated BB+ or worse from either Standard \& Poor's, Moody's or Fitch are included. Maturity and all financial ratios have been winsorized at the 1\% and $99 \%$ levels. ${ }^{* *},{ }^{* *}$, and * indicate statistical significance at $1 \%, 5 \%$, and $10 \%$.

Panel A: Covenant-lite loans vs. public bonds

\begin{tabular}{|c|c|c|c|c|c|c|c|c|}
\hline & Obs. & $\begin{array}{l}\text { Covenant-lite } \\
\text { Mean } \\
\text { (St.dev.) }\end{array}$ & Median & Obs. & $\begin{array}{l}\text { Public bond } \\
\text { Mean } \\
\text { (St.dev.) }\end{array}$ & Median & $\begin{array}{c}\text { Difference } \\
\text { in means } \\
\text { (t-statistic) }\end{array}$ & $\begin{array}{l}\text { Difference } \\
\text { in medians } \\
\text { (z-statistic) }\end{array}$ \\
\hline Deal size (million) & 920 & $\begin{array}{c}839.443 \\
(1081.679)\end{array}$ & 521.933 & 2044 & $\begin{array}{c}529.616 \\
(450.679)\end{array}$ & 400.296 & $\begin{array}{c}309.826^{* * *} \\
(8.37)\end{array}$ & $\begin{array}{c}121.636^{* * * *} \\
(8.61)\end{array}$ \\
\hline Maturity & 920 & $\begin{array}{c}6.257 \\
(0.856)\end{array}$ & 6.562 & 2044 & $\begin{array}{c}7.608 \\
(1.807)\end{array}$ & 7.526 & $\begin{array}{c}-1.350 * * * \\
(-27.60)\end{array}$ & $\begin{array}{c}-0.964 * * * \\
(-23.40)\end{array}$ \\
\hline Senior & 638 & $\begin{array}{l}1.000 \\
(0.000)\end{array}$ & 1.000 & 2044 & $\begin{array}{c}0.869 \\
(0.337)\end{array}$ & 1.000 & $\begin{array}{c}0.131^{* * *} \\
(17.52)\end{array}$ & $\begin{array}{c}0.000 * * * \\
(9.62)\end{array}$ \\
\hline Rating & 920 & $\begin{array}{c}5.143 \\
(1.201)\end{array}$ & 5.000 & 2044 & $\begin{array}{c}5.541 \\
(1.915)\end{array}$ & 6.000 & $\begin{array}{c}-0.398 * * * \\
(-6.86)\end{array}$ & $\begin{array}{c}-1.000 * * * \\
(-7.85)\end{array}$ \\
\hline Firm age & 913 & $\begin{array}{c}45.055 \\
(41.981)\end{array}$ & 30.000 & 2034 & $\begin{array}{c}47.565 \\
(40.748)\end{array}$ & 31.000 & $\begin{array}{l}-2.511 \\
(-1.51)\end{array}$ & $\begin{array}{l}-1.000 \\
(-1.50)\end{array}$ \\
\hline
\end{tabular}




\begin{tabular}{|c|c|c|c|c|c|c|c|c|}
\hline Current ratio & 450 & $\begin{array}{c}1.958 \\
(1.373)\end{array}$ & 1.594 & 1970 & $\begin{array}{c}1.826 \\
(1.512)\end{array}$ & 1.488 & $\begin{array}{l}0.132 * \\
(1.81)\end{array}$ & $\begin{array}{c}0.106^{* * *} \\
(3.62)\end{array}$ \\
\hline Profitability & 450 & $\begin{array}{c}0.124 \\
(0.079)\end{array}$ & 0.111 & 1971 & $\begin{array}{c}0.122 \\
(0.078)\end{array}$ & 0.114 & $\begin{array}{l}0.002 \\
(0.43)\end{array}$ & $\begin{array}{l}-0.003 \\
(-0.58)\end{array}$ \\
\hline Tangibility & 453 & $\begin{array}{c}0.241 \\
(0.219) \\
\end{array}$ & 0.157 & 1980 & $\begin{array}{c}0.381 \\
(0.275) \\
\end{array}$ & 0.351 & $\begin{array}{c}-0.140^{* * * *} \\
(-11.62)\end{array}$ & $\begin{array}{c}-0.195 * * * \\
(-9.83)\end{array}$ \\
\hline
\end{tabular}

Panel B: Covenant-lite loans vs. Rule 144a bonds

\begin{tabular}{|c|c|c|c|c|c|c|c|c|}
\hline & Obs. & $\begin{array}{l}\text { Covenant-lite } \\
\text { Mean } \\
\text { (St.dev.) }\end{array}$ & Median & Obs. & $\begin{array}{l}\text { Rule 144a bo } \\
\text { Mean } \\
\text { (St.dev.) }\end{array}$ & Median & $\begin{array}{l}\text { Difference } \\
\text { in means } \\
\text { (t-statistic) }\end{array}$ & $\begin{array}{l}\text { Difference } \\
\text { in medians } \\
\text { (z-statistic) }\end{array}$ \\
\hline Deal size (million) & 920 & $\begin{array}{c}839.443 \\
(1081.679)\end{array}$ & 521.933 & 2369 & $\begin{array}{c}483.904 \\
(416.275)\end{array}$ & 362.087 & $\begin{array}{c}355.539 * * * \\
(9.69)\end{array}$ & $\begin{array}{c}159.845^{* * *} \\
(11.28)\end{array}$ \\
\hline Maturity & 920 & $\begin{array}{c}6.257 \\
(0.856)\end{array}$ & 6.562 & 2369 & $\begin{array}{c}7.678 \\
(1.698)\end{array}$ & 8.016 & $\begin{array}{c}-1.421 * * * \\
(-31.66)\end{array}$ & $\begin{array}{c}-1.455^{* * *} \\
(-26.10)\end{array}$ \\
\hline Senior & 638 & $\begin{array}{c}1.000 \\
(0.000)\end{array}$ & 1.000 & 2369 & $\begin{array}{c}0.907 \\
(0.291)\end{array}$ & 1.000 & $\begin{array}{c}0.093 * * * \\
(15.61)\end{array}$ & $\begin{array}{c}0.000 * * * \\
(8.01)\end{array}$ \\
\hline Rating & 920 & $\begin{array}{c}5.143 \\
(1.201)\end{array}$ & 5.000 & 2369 & $\begin{array}{l}5.808 \\
(1.818)\end{array}$ & 6.000 & $\begin{array}{c}-0.664 * * * \\
(-12.20)\end{array}$ & $\begin{array}{c}-1.000 * * * \\
(-12.43)\end{array}$ \\
\hline Firm age & 913 & $\begin{array}{c}45.055 \\
(41.981)\end{array}$ & 30.000 & 2332 & $\begin{array}{c}45.822 \\
(41.858)\end{array}$ & 29.000 & $\begin{array}{l}-0.767 \\
(-0.47)\end{array}$ & $\begin{array}{l}1.000 \\
(0.35)\end{array}$ \\
\hline Current ratio & 450 & $\begin{array}{c}1.958 \\
(1.373)\end{array}$ & 1.594 & 1970 & $\begin{array}{c}1.811 \\
(1.482)\end{array}$ & 1.485 & $\begin{array}{c}0.147 * * \\
(2.02)\end{array}$ & $\begin{array}{c}0.109 * * * \\
(3.65)\end{array}$ \\
\hline Profitability & 450 & $\begin{array}{c}0.124 \\
(0.079)\end{array}$ & 0.111 & 1966 & $\begin{array}{c}0.126 \\
(0.083)\end{array}$ & 0.118 & $\begin{array}{l}-0.002 \\
(-0.44)\end{array}$ & $\begin{array}{c}-0.007^{*} \\
(-1.74)\end{array}$ \\
\hline
\end{tabular}




\begin{tabular}{|c|c|c|c|c|c|c|c|c|}
\hline Tangibility & 453 & $\begin{array}{c}0.241 \\
(0.219)\end{array}$ & 0.157 & 1982 & $\begin{array}{c}0.363 \\
(0.274)\end{array}$ & 0.317 & $\begin{array}{c}-0.122 * * * \\
(-10.19)\end{array}$ & $\begin{array}{c}-0.160 * * * \\
(-8.59)\end{array}$ \\
\hline
\end{tabular}




\section{Table 2: Issuer SEC registration status}

This table presents issuer SEC registration status for the four types of debt instruments in the sample. Rule 144A bonds are broken out into those never exchanged for another issue and those subsequently exchanged for another bond, a proxy for the Rule 144a bond being replaced by an SEC registered public bond. An issuer is considered registered with the SEC if data on total assets at the end of the fiscal year prior to debt issuance is available in Compustat or in Capital IQ. If assets are available only in Capital IQ, the filing source reported by Capital IQ must be an SEC filing. In the case of bonds, the issuance of the bond itself may be the reason for SEC registration. The registration statement generally reports financial information for the past two years, and several months may pass between filing the registration statement and issuing the bond. Therefore, newly registered bond issuers with asset data available as of the past fiscal year, but no asset data available as of three years prior to the past fiscal year and no IPO reported in SDC during these three years are counted as unregistered prior to bond issuance. Among registered issuers, those that continue to file financial statements three years after debt issuance are considered to be continuously registered, while registered issuers that stop filing financial statements within three years after debt issuance are counted as deregistering. If deregistration is due to a bankruptcy or merger, we do not treat the firm as deregistered. The sample period ranges from January 1, 2005 through April 30, 2015. Covenant-lite loans are taken from LCD and bonds are taken from Mergent FISD.

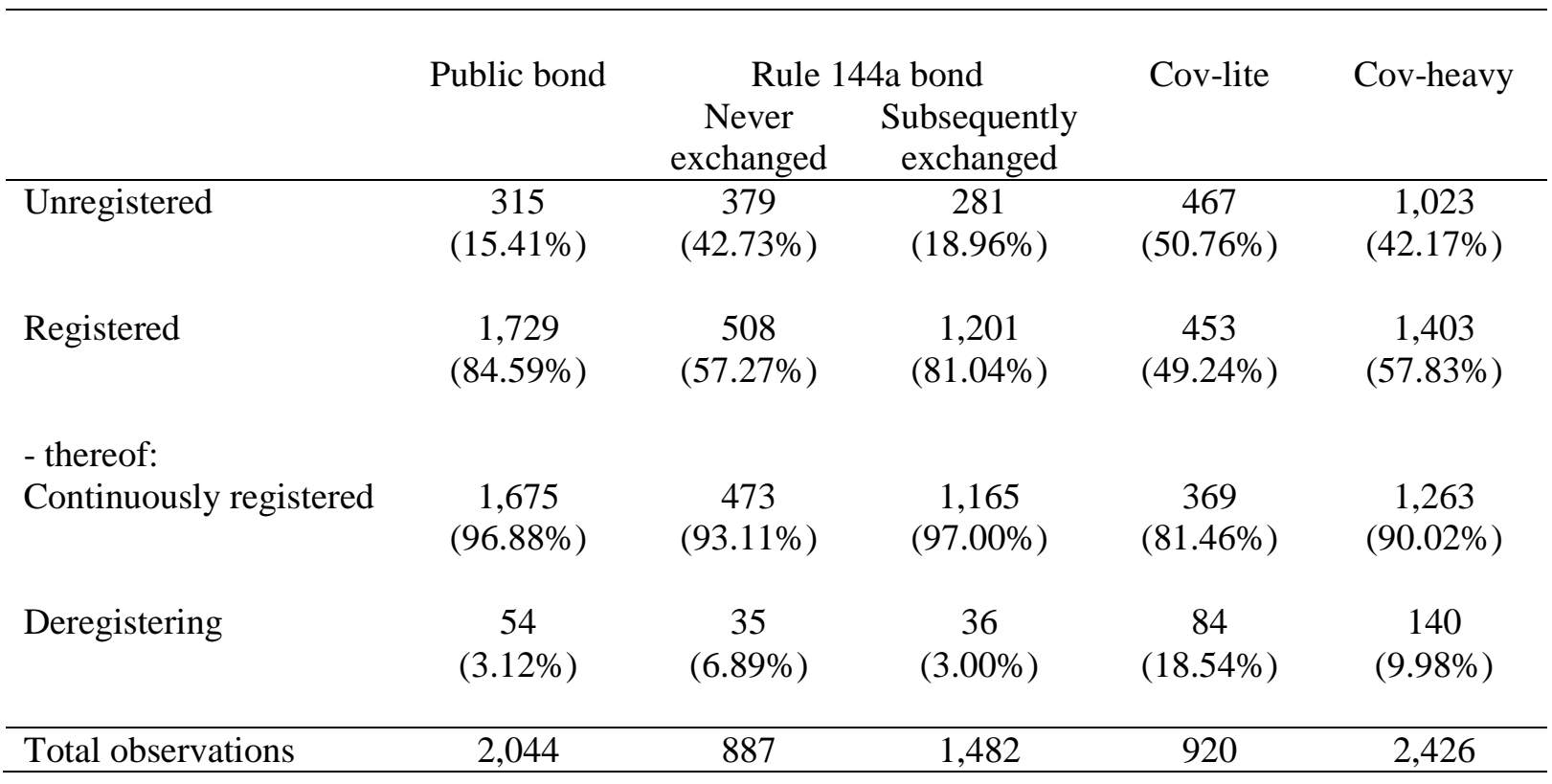


Table 3: Multinomial logit regressions for the choice between different instrument types depending on SEC registration status

This table presents results from multinomial logit regressions modeling the choice between public bonds, Rule 144a bonds, Rule 144a bonds that end up being exchanged, Rule 144a bonds that are never exchanged, covenant-lite loans, and covenant-heavy loans. Public bonds act as the base group. The sample period ranges from January 1, 2005 through April 30, 2015. A rating worse than CCC+ perfectly predicts that the issued instrument is not covenant-lite, thus instruments rated CCC+ or worse are aggregated into one category. Covenant-lite loans are taken from LCD and bonds are taken from Mergent FISD. Ratings are denoted by indicator variables, with a $\mathrm{BB}+$ rating acting as the base group in the regressions. Industry fixed effects are based on the LCD industry classification. Standard errors are adjusted for clustering by firm and time. $* * *, * *$, and $*$ indicate statistical significance at $1 \%, 5 \%$, and $10 \%$.

\begin{tabular}{|c|c|c|c|c|}
\hline & $\begin{array}{l}\text { Exchanged } \\
\text { Rule 144a } \\
(1) \\
\end{array}$ & $\begin{array}{c}\text { Never } \\
\text { exchanged } \\
\text { Rule 144a } \\
(2)\end{array}$ & Cov-lite & Cov-heavy \\
\hline Unregistered & $\begin{array}{c}1.26^{* * *} \\
(3.05)\end{array}$ & $\begin{array}{c}4.34^{* * * *} \\
(10.42)\end{array}$ & $\begin{array}{c}7.75^{* * *} \\
(8.49)\end{array}$ & $\begin{array}{c}6.75^{* * *} \\
(9.36)\end{array}$ \\
\hline Deregistering & $\begin{array}{c}0.94 \\
(-0.28)\end{array}$ & $\begin{array}{c}2.20^{* * *} \\
(2.85)\end{array}$ & $\begin{array}{c}11.27 * * * \\
(7.91)\end{array}$ & $\begin{array}{c}4.35^{* * *} \\
(5.74)\end{array}$ \\
\hline Ln(Firm age) & $\begin{array}{c}0.97 \\
(-0.82)\end{array}$ & $\begin{array}{c}0.97 \\
(-0.85)\end{array}$ & $\begin{array}{l}0.84 * * \\
(-2.52)\end{array}$ & $\begin{array}{c}0.80 * * * \\
(-4.18)\end{array}$ \\
\hline Ln(Maturity) & $\begin{array}{c}5.11 * * * \\
(5.65)\end{array}$ & $\begin{array}{c}0.81 \\
(-0.81)\end{array}$ & $\begin{array}{c}0.01^{* * * *} \\
(-7.90)\end{array}$ & $\begin{array}{l}0.00 * * * \\
(-13.72)\end{array}$ \\
\hline Ln(Deal size) & $\begin{array}{c}0.79 * * * \\
(-3.87)\end{array}$ & $\begin{array}{c}0.94 \\
(-0.94)\end{array}$ & $\begin{array}{c}2.07 * * * \\
(4.97)\end{array}$ & $\begin{array}{c}1.40 * * * \\
(3.00)\end{array}$ \\
\hline $\mathrm{BB}$ & $\begin{array}{c}1.17 \\
(0.83)\end{array}$ & $\begin{array}{c}1.02 \\
(0.05)\end{array}$ & $\begin{array}{c}1.54 \\
(0.91)\end{array}$ & $\begin{array}{c}1.33 \\
(1.03)\end{array}$ \\
\hline BB- & $\begin{array}{c}1.49 * * * \\
(3.30)\end{array}$ & $\begin{array}{c}1.42 \\
(0.83)\end{array}$ & $\begin{array}{c}3.46^{* * *} \\
(4.40)\end{array}$ & $\begin{array}{c}2.01^{* * *} \\
(3.78)\end{array}$ \\
\hline $\mathrm{B}+$ & $\begin{array}{c}1.42 * * * \\
(2.94)\end{array}$ & $\begin{array}{c}1.17 \\
(0.43)\end{array}$ & $\begin{array}{c}3.89 * * * \\
(4.01)\end{array}$ & $\begin{array}{c}1.53 \\
(1.53)\end{array}$ \\
\hline B & $\begin{array}{l}1.55 * * \\
(2.26)\end{array}$ & $\begin{array}{c}1.20 \\
(0.57)\end{array}$ & $\begin{array}{c}2.73^{* * *} \\
(3.96)\end{array}$ & $\begin{array}{c}0.73 \\
(-1.19)\end{array}$ \\
\hline B- & $\begin{array}{c}1.67 * * * \\
(2.61)\end{array}$ & $\begin{array}{c}1.08 \\
(0.21)\end{array}$ & $\begin{array}{c}0.30 * * * \\
(-5.68)\end{array}$ & $\begin{array}{c}0.07 * * * \\
(-8.82)\end{array}$ \\
\hline CCC + or worse & $1.97 * * *$ & 1.23 & $0.02 * * *$ & $0.02 * * *$ \\
\hline
\end{tabular}




\section{$\begin{array}{llll}(4.67) \quad(0.75) & (-9.79) \quad(-11.69)\end{array}$}

\begin{tabular}{|c|c|c|c|c|}
\hline $\begin{array}{l}\text { Year effects } \\
\text { Industry effects }\end{array}$ & $\begin{array}{l}\text { Yes } \\
\text { Yes }\end{array}$ & $\begin{array}{l}\text { Yes } \\
\text { Yes }\end{array}$ & $\begin{array}{l}\text { Yes } \\
\text { Yes }\end{array}$ & $\begin{array}{l}\text { Yes } \\
\text { Yes }\end{array}$ \\
\hline \multicolumn{5}{|c|}{ Test unregistered (cov-lite) = unregistered (this instrument) } \\
\hline$C h i^{2}$ & $73.40^{* * *}$ & $5.29 * *$ & & 1.86 \\
\hline$p$-value & 0.000 & 0.021 & & 0.173 \\
\hline \multicolumn{5}{|c|}{ Test deregistering (cov-lite) = deregistering (this instrument) } \\
\hline$C h i^{2}$ & $43.70^{* * *}$ & $22.44^{* * *}$ & & $19.33^{* * *}$ \\
\hline$p$-value & 0.000 & 0.000 & & 0.000 \\
\hline \multicolumn{5}{|c|}{$\begin{array}{l}\text { Test unregistered (Never exchanged Rule 144a) = unregistered (this } \\
\text { instrument) }\end{array}$} \\
\hline$C h i^{2}$ & $122.91 * * *$ & & $5.29 * *$ & $4.81^{* *}$ \\
\hline$p$-value & 0.000 & & 0.021 & 0.028 \\
\hline \multicolumn{5}{|c|}{$\begin{array}{l}\text { Test deregistering (Never exchanged Rule 144a) = deregistering (this } \\
\text { instrument) }\end{array}$} \\
\hline$C h i^{2}$ & $12.21^{* * *}$ & & $22.44^{* * *}$ & $5.07 * *$ \\
\hline$p$-value & 0.001 & & 0.000 & 0.024 \\
\hline Observations & 7578 & & & \\
\hline
\end{tabular}




\section{Table 4: Differences in spreads across debt instrument types}

This table presents results from regressions of spreads on indicators of covenant-lite loans, covenant-heavy loans, and control variables including firm financials. Junior debt is excluded from this analysis. For loans, this analysis only includes a loan's first lien institutional tranche. Debt instruments rated CCC+ or worse are excluded since there are only five cov-lite loans with such a rating. All regressions include five debt instrument types: cov-lite loans, cov-heavy loans, public bonds, subsequently exchanged Rule 144a bonds, and Rule 144a bonds that were never exchanged. Public bonds to unregistered firms act as the base group. Loan spreads are expressed as spreads over LIBOR. Columns (1) through (4) define bond spreads as the bond yield minus the linearly interpolated rate for swapping a fixed rate interest rate into 3-month LIBOR. Columns (5) through (8) augment the usable sample by assuming that all bonds were issued at par and calculating spreads for such bonds as the coupon rate minus the linearly interpolated rate for swapping a fixed rate interest rate into 3-month LIBOR. Columns (3), (4), (7), and (8) restrict the sample to registered issuers for whom financial data are available. Covenant-lite loans are taken from LCD and bonds are taken from Mergent FISD. Standard errors are adjusted for clustering at the firm and time levels. ${ }^{* * *}, * *$, and $*$ indicate statistical significance at $1 \%, 5 \%$, and $10 \%$.

Panel A: Accounting for exchanged Rule 144a vs. never exchanged Rule 144a

\begin{tabular}{|c|c|c|c|c|c|c|c|c|}
\hline & \multicolumn{4}{|c|}{ Yield spreads } & \multicolumn{4}{|c|}{ Coupon spreads } \\
\hline & (1) & (2) & (3) & (4) & (5) & (6) & (7) & (8) \\
\hline $\begin{array}{l}\text { Covenant lite } \\
\text { loan }\end{array}$ & $\begin{array}{c}-91.169 * * * \\
(-5.91)\end{array}$ & $\begin{array}{c}-71.894 * * * \\
(-4.68)\end{array}$ & $\begin{array}{c}-62.479 * * * \\
(-3.89)\end{array}$ & $\begin{array}{c}-75.593 * * * \\
(-4.55)\end{array}$ & $\begin{array}{c}-132.233^{* * *} \\
(-9.45)\end{array}$ & $\begin{array}{c}-112.190 * * * \\
(-7.78)\end{array}$ & $\begin{array}{c}-115.257 * * * \\
(-7.46)\end{array}$ & $\begin{array}{c}-125.625^{* * * *} \\
(-8.19)\end{array}$ \\
\hline $\begin{array}{l}\text { Unregistered x } \\
\text { cov-lite }\end{array}$ & & $\begin{array}{c}-113.417 * * \\
(-2.15)\end{array}$ & & & & $\begin{array}{c}-54.829 * * * \\
(-3.32)\end{array}$ & & \\
\hline $\begin{array}{l}\text { Covenant heavy } \\
\text { loan }\end{array}$ & $\begin{array}{c}-75.073 * * * \\
(-4.11)\end{array}$ & $\begin{array}{c}-70.568 * * * \\
(-3.84)\end{array}$ & $\begin{array}{c}-67.416 * * * \\
(-3.77)\end{array}$ & $\begin{array}{c}-83.880 * * * \\
(-4.28)\end{array}$ & $\begin{array}{c}-119.058^{* * * *} \\
(-7.29)\end{array}$ & $\begin{array}{c}-112.926^{* * *} \\
(-6.82)\end{array}$ & $\begin{array}{c}-121.666^{* * *} \\
(-7.19)\end{array}$ & $\begin{array}{c}-135.532 * * * \\
(-7.48)\end{array}$ \\
\hline $\begin{array}{l}\text { Unregistered x } \\
\text { cov-heavy }\end{array}$ & & $\begin{array}{r}-81.477 \\
(-1.56)\end{array}$ & & & & $\begin{array}{l}-24.876 \\
(-1.51)\end{array}$ & & \\
\hline $\begin{array}{l}\text { Never exchanged } \\
\text { Rule 144a }\end{array}$ & $\begin{array}{c}86.870 * * * \\
(6.74)\end{array}$ & $\begin{array}{c}75.939 * * * \\
(5.56)\end{array}$ & $\begin{array}{c}85.685^{* * * *} \\
(6.34)\end{array}$ & $\begin{array}{c}81.757 * * * \\
(6.08)\end{array}$ & $\begin{array}{c}35.118^{* * * *} \\
(3.71)\end{array}$ & $\begin{array}{c}25.839 * * \\
(2.57)\end{array}$ & $\begin{array}{c}28.364 * * * \\
(2.71)\end{array}$ & $\begin{array}{c}28.583^{* * *} \\
(2.82)\end{array}$ \\
\hline $\begin{array}{l}\text { Unregistered x } \\
\text { never exchanged }\end{array}$ & & $\begin{array}{l}-44.371 \\
(-0.75)\end{array}$ & & & & $\begin{array}{l}11.523 \\
(0.68)\end{array}$ & & \\
\hline
\end{tabular}




\begin{tabular}{|c|c|c|c|c|c|c|c|c|}
\hline $\begin{array}{l}\text { Exchanged } \\
\text { Rule 144a }\end{array}$ & $\begin{array}{c}26.596 * * \\
(2.33)\end{array}$ & $\begin{array}{c}25.216 * * \\
(2.20)\end{array}$ & $\begin{array}{c}29.568 * * * \\
(2.95)\end{array}$ & $\begin{array}{c}23.919 * * \\
(2.41)\end{array}$ & $\begin{array}{l}-7.479 \\
(-1.19)\end{array}$ & $\begin{array}{l}-9.108 \\
(-1.37)\end{array}$ & $\begin{array}{l}-9.769 \\
(-1.40)\end{array}$ & $\begin{array}{c}-11.573 * \\
(-1.65)\end{array}$ \\
\hline $\begin{array}{l}\text { Unregistered x } \\
\text { Exchanged }\end{array}$ & & $\begin{array}{c}-58.654 \\
(-1.15)\end{array}$ & & & & $\begin{array}{l}3.277 \\
(0.21)\end{array}$ & & \\
\hline Unregistered & $\begin{array}{c}32.258 * * * \\
(5.91)\end{array}$ & $\begin{array}{c}112.382 * * \\
(2.11)\end{array}$ & & & $\begin{array}{c}34.315^{* * *} \\
(5.86)\end{array}$ & $\begin{array}{c}54.352 * * * \\
(3.52)\end{array}$ & & \\
\hline Ln(Firm age) & $\begin{array}{c}-4.940 * * \\
(-2.16)\end{array}$ & $\begin{array}{c}-4.750 * * \\
(-2.02)\end{array}$ & $\begin{array}{l}-2.003 \\
(-0.60)\end{array}$ & $\begin{array}{l}0.846 \\
(0.27)\end{array}$ & $\begin{array}{l}-1.947 \\
(-0.79)\end{array}$ & $\begin{array}{l}-1.672 \\
(-0.67)\end{array}$ & $\begin{array}{l}2.052 \\
(0.61)\end{array}$ & $\begin{array}{l}5.487^{*} \\
(1.65)\end{array}$ \\
\hline Ln(Maturity) & $\begin{array}{c}-176.622 * * * \\
(-7.50)\end{array}$ & $\begin{array}{c}-170.843^{* * *} \\
(-7.10)\end{array}$ & $\begin{array}{c}-164.806^{* * *} \\
(-6.19)\end{array}$ & $\begin{array}{c}-168.004^{* * *} \\
(-6.50)\end{array}$ & $\begin{array}{c}-208.421^{* * * *} \\
(-9.33)\end{array}$ & $\begin{array}{c}-202.771 * * * \\
(-8.97)\end{array}$ & $\begin{array}{c}-217.131 * * * \\
(-8.74)\end{array}$ & $\begin{array}{c}-216.639 * * * \\
(-9.15)\end{array}$ \\
\hline Ln(Deal size) & $\begin{array}{c}-6.916^{* *} \\
(-2.53)\end{array}$ & $\begin{array}{c}-7.732 * * * \\
(-2.78)\end{array}$ & $\begin{array}{l}-3.719 \\
(-1.23)\end{array}$ & $\begin{array}{l}5.529 \\
(1.60)\end{array}$ & $\begin{array}{c}-9.094^{* * * *} \\
(-3.65)\end{array}$ & $\begin{array}{c}-10.089 * * * \\
(-4.03)\end{array}$ & $\begin{array}{c}-5.282 * \\
(-1.78)\end{array}$ & $\begin{array}{c}6.166^{* *} \\
(1.99)\end{array}$ \\
\hline Ln(Assets) & & & & $\begin{array}{c}-15.472 * * * \\
(-3.97)\end{array}$ & & & & $\begin{array}{c}-17.301^{* * *} \\
(-4.66)\end{array}$ \\
\hline Leverage & & & & $\begin{array}{c}-33.029 * * * \\
(-2.67)\end{array}$ & & & & $\begin{array}{c}-25.265^{* *} \\
(-2.14)\end{array}$ \\
\hline Current ratio & & & & $\begin{array}{l}-0.610 \\
(-0.28)\end{array}$ & & & & $\begin{array}{l}-1.042 \\
(-0.47)\end{array}$ \\
\hline \multirow{2}{*}{$\begin{array}{l}\text { Ln(1+Coverage } \\
\text { Ratio) }\end{array}$} & & & & $-8.602 * * *$ & & & & $-9.926 * * *$ \\
\hline & & & & $(-2.77)$ & & & & $(-2.72)$ \\
\hline Tangibility & & & & $\begin{array}{c}24.726 \\
(1.61)\end{array}$ & & & & $\begin{array}{c}20.576 \\
(1.37)\end{array}$ \\
\hline Constant & $\begin{array}{c}540.720^{* * *} \\
(9.17)\end{array}$ & $\begin{array}{c}526.946 * * * \\
(8.73)\end{array}$ & $\begin{array}{l}484.219 * * * \\
\quad(6.79)\end{array}$ & $\begin{array}{c}585.636^{* * *} \\
(7.23)\end{array}$ & $\begin{array}{c}647.028^{* * *} \\
(11.26)\end{array}$ & $\begin{array}{c}633.312 * * * \\
(10.82)\end{array}$ & $\begin{array}{c}647.364^{* * *} \\
(9.56)\end{array}$ & $\begin{array}{c}738.805^{* * * *} \\
(9.60)\end{array}$ \\
\hline Rating effects & Yes & Yes & Yes & Yes & Yes & Yes & Yes & Yes \\
\hline Year-quarter & Yes & Yes & Yes & Yes & Yes & Yes & Yes & Yes \\
\hline
\end{tabular}




\begin{tabular}{|c|c|c|c|c|c|c|c|c|}
\hline Industry effects & Yes & Yes & Yes & Yes & Yes & Yes & Yes & Yes \\
\hline \multicolumn{9}{|c|}{ Test cov-lite = cov-heavy } \\
\hline $\mathrm{Chi}^{2}$ & $4.30 * *$ & 0.02 & 0.24 & 0.64 & $2.73 *$ & 0.01 & 0.36 & 0.82 \\
\hline$p$-value & 0.038 & 0.880 & 0.626 & 0.425 & 0.098 & 0.934 & 0.550 & 0.366 \\
\hline \multicolumn{9}{|c|}{ Test unregistered cov-lite $=$ unregistered cov-heavy } \\
\hline$C h i^{2}$ & & $18.08^{* * *}$ & & & & $15.70 * * *$ & & \\
\hline$p$-value & & 0.000 & & & & 0.000 & & \\
\hline Observations & 4842 & 4842 & 2922 & 2922 & 5917 & 5917 & 3802 & 3802 \\
\hline
\end{tabular}

Panel B: Pooling all Rule 144a bonds

\begin{tabular}{|c|c|c|c|c|c|c|c|c|}
\hline & \multicolumn{4}{|c|}{ Yield spreads } & \multicolumn{4}{|c|}{ Coupon spreads } \\
\hline & (1) & (2) & (3) & (4) & (5) & (6) & (7) & (8) \\
\hline $\begin{array}{l}\text { Covenant lite } \\
\text { loan }\end{array}$ & $\begin{array}{c}-100.024 * * * \\
(-6.13)\end{array}$ & $\begin{array}{c}-77.257 * * * \\
(-4.75)\end{array}$ & $\begin{array}{c}-68.826 * * * \\
(-4.02)\end{array}$ & $\begin{array}{c}-81.976 * * * \\
(-4.66)\end{array}$ & $\begin{array}{c}-135.975^{* * * *} \\
(-9.54)\end{array}$ & $\begin{array}{c}-114.452 * * * \\
(-7.80)\end{array}$ & $\begin{array}{c}-117.782 * * * \\
(-7.50)\end{array}$ & $\begin{array}{c}-128.211 * * * \\
(-8.21)\end{array}$ \\
\hline $\begin{array}{l}\text { Unregistered x } \\
\text { cov-lite }\end{array}$ & & $\begin{array}{c}-112.293^{* *} \\
(-2.18)\end{array}$ & & & & $\begin{array}{c}-54.418 * * * \\
(-3.29)\end{array}$ & & \\
\hline $\begin{array}{l}\text { Covenant heavy } \\
\text { loan }\end{array}$ & $\begin{array}{c}-82.774 * * * \\
(-4.37)\end{array}$ & $\begin{array}{c}-74.467 * * * \\
(-3.90)\end{array}$ & $\begin{array}{c}-72.136 * * * \\
(-3.87)\end{array}$ & $\begin{array}{c}-88.564 * * * \\
(-4.36)\end{array}$ & $\begin{array}{c}-121.991^{* * * *} \\
(-7.39)\end{array}$ & $\begin{array}{c}-114.348^{* * *} \\
(-6.82)\end{array}$ & $\begin{array}{c}-123.287 * * * \\
(-7.22)\end{array}$ & $\begin{array}{c}-137.141^{* * *} \\
(-7.51)\end{array}$ \\
\hline $\begin{array}{l}\text { Unregistered x } \\
\text { cov-heavy }\end{array}$ & & $\begin{array}{l}-80.790 \\
(-1.58)\end{array}$ & & & & $\begin{array}{l}-24.663 \\
(-1.50)\end{array}$ & & \\
\hline Rule $144 \mathrm{a}$ & $\begin{array}{c}46.958^{* * *} \\
\quad(4.20)\end{array}$ & $\begin{array}{c}40.156^{* * * *} \\
(3.72)\end{array}$ & $\begin{array}{c}46.371 * * * \\
(4.83)\end{array}$ & $\begin{array}{c}41.395 * * * \\
(4.35)\end{array}$ & $\begin{array}{l}8.424 \\
(1.35)\end{array}$ & $\begin{array}{l}1.900 \\
(0.32)\end{array}$ & $\begin{array}{l}2.385 \\
(0.38)\end{array}$ & $\begin{array}{l}1.237 \\
(0.20)\end{array}$ \\
\hline $\begin{array}{l}\text { Unregistered x } \\
\text { Rule } 144 a\end{array}$ & & $\begin{array}{l}-35.224 \\
(-0.67)\end{array}$ & & & & $\begin{array}{l}18.179 \\
(1.62)\end{array}$ & & \\
\hline Unregistered & $\begin{array}{l}37.131^{* * *} \\
(7.18)\end{array}$ & $\begin{array}{c}111.797^{* * *} \\
(2.14)\end{array}$ & & & $\begin{array}{l}37.309 * * * \\
\quad(6.53)\end{array}$ & $\begin{array}{l}54.215^{* * *} \\
(3.50)\end{array}$ & & \\
\hline Ln(Firm age) & $\begin{array}{c}-4.887 * * \\
(-2.09)\end{array}$ & $\begin{array}{l}-4.592^{*} \\
(-1.90)\end{array}$ & $\begin{array}{l}-1.802 \\
(-0.53)\end{array}$ & $\begin{array}{l}0.935 \\
(0.29)\end{array}$ & $\begin{array}{l}-1.920 \\
(-0.77)\end{array}$ & $\begin{array}{l}-1.602 \\
(-0.63)\end{array}$ & $\begin{array}{l}2.117 \\
(0.62)\end{array}$ & $\begin{array}{l}5.454 \\
(1.62)\end{array}$ \\
\hline
\end{tabular}




\begin{tabular}{|c|c|c|c|c|c|c|c|c|}
\hline Ln(Maturity) & $\begin{array}{c}-188.581^{* * *} \\
(-7.69)\end{array}$ & $\begin{array}{c}-179.165 * * * \\
(-7.11)\end{array}$ & $\begin{array}{c}-174.385^{* * * *} \\
(-6.15)\end{array}$ & $\begin{array}{c}-177.724 * * * \\
(-6.43)\end{array}$ & $\begin{array}{c}-213.919 * * * \\
(-9.50)\end{array}$ & $\begin{array}{c}-206.578 * * * \\
(-9.01)\end{array}$ & $\begin{array}{c}-221.168 * * * \\
(-8.80)\end{array}$ & $\begin{array}{c}-220.803^{* * *} \\
(-9.20)\end{array}$ \\
\hline Ln(Deal size) & $\begin{array}{c}-5.485^{* *} \\
(-2.05)\end{array}$ & $\begin{array}{c}-6.888 * * \\
(-2.49)\end{array}$ & $\begin{array}{l}-2.588 \\
(-0.86)\end{array}$ & $\begin{array}{l}6.505^{*} \\
(1.87)\end{array}$ & $\begin{array}{c}-8.289 * * * \\
(-3.40)\end{array}$ & $\begin{array}{c}-9.615^{* * *} \\
(-3.88)\end{array}$ & $\begin{array}{l}-4.653 \\
(-1.59)\end{array}$ & $\begin{array}{c}6.657^{* *} \\
(2.14)\end{array}$ \\
\hline Ln(Assets) & & & & $\begin{array}{c}-15.166 * * * \\
(-3.87)\end{array}$ & & & & $\begin{array}{c}-17.057 * * * \\
(-4.57)\end{array}$ \\
\hline Leverage & & & & $\begin{array}{c}-32.091 * * \\
(-2.48)\end{array}$ & & & & $\begin{array}{c}-24.829 * * \\
(-2.05)\end{array}$ \\
\hline Current ratio & & & & $\begin{array}{l}-1.172 \\
(-0.52)\end{array}$ & & & & $\begin{array}{l}-1.383 \\
(-0.61)\end{array}$ \\
\hline Ln(1+Coverage & & & & $-8.696 * * *$ & & & & $-10.003 * * *$ \\
\hline Kdtio) & & & & $(-2.78)$ & & & & $(-2.74)$ \\
\hline Tangibility & & & & $\begin{array}{c}21.739 \\
(1.40)\end{array}$ & & & & $\begin{array}{l}18.884 \\
(1.24)\end{array}$ \\
\hline Constant & $\begin{array}{c}555.262^{* * *} \\
(9.31)\end{array}$ & $\begin{array}{c}535.088^{* * * *} \\
(8.73)\end{array}$ & $\begin{array}{l}495.142 * * * \\
\quad(6.83)\end{array}$ & $\begin{array}{c}597.845^{* * *} \\
(7.17)\end{array}$ & $\begin{array}{c}651.024 * * * \\
(11.37)\end{array}$ & $\begin{array}{c}635.439 * * * \\
(10.83)\end{array}$ & $\begin{array}{c}650.204^{* * *} \\
\quad(9.64)\end{array}$ & $\begin{array}{c}742.486^{* * *} \\
(9.64)\end{array}$ \\
\hline Rating effects & Yes & Yes & Yes & Yes & Yes & Yes & Yes & Yes \\
\hline $\begin{array}{l}\text { Year-quarter } \\
\text { effects }\end{array}$ & Yes & Yes & Yes & Yes & Yes & Yes & Yes & Yes \\
\hline Industry effects & Yes & Yes & Yes & Yes & Yes & Yes & Yes & Yes \\
\hline \multicolumn{9}{|c|}{ Test cov-lite $=$ cov-heavy } \\
\hline$C h i^{2}$ & $4.99 * *$ & 0.10 & 0.11 & 0.42 & $3.08^{*}$ & 0.00 & 0.27 & 0.67 \\
\hline$p$-value & 0.026 & 0.749 & 0.739 & 0.519 & 0.079 & 0.991 & 0.606 & 0.413 \\
\hline \multicolumn{9}{|c|}{ Test unregistered cov-lite $=$ unregistered cov-heavy } \\
\hline$C h i^{2}$ & & $17.81^{* * *}$ & & & & $15.63^{* * *}$ & & \\
\hline$p$-value & & 0.000 & & & & 0.000 & & \\
\hline Observations & 4842 & 4842 & 2922 & 2922 & 5917 & 5917 & 3802 & 3802 \\
\hline
\end{tabular}




\section{Table 5: Differences in spreads cov-lite vs. cov-heavy - within firm and within deal}

Panel A of this table reports the average treatment effect on the treated for the spread paid over LIBOR for a matching of institutional cov-lite loans with institutional cov-heavy loans issued by the same firm. Column (1) matches each cov-lite loan with a cov-heavy loan issued by the same firm within the same year, choosing the nearest neighbor in terms of deal size and maturity using the Mahalanobis distance. Column (2) performs an exact match on the issuer, and chooses the nearest neighbor in terms of launch date, requiring that the launch dates of the two loans are in the same or adjacent calendar year. Column (3) performs the same analysis as Column (2), but adds an exact match on the firm's rating to ensure that credit quality has not changed. Panel B presents regressions explaining the difference between the credit spread paid on a loan's first lien institutional tranche and its revolving line of credit on an indicator of whether or not the institutional loan is cov-lite. Only loans that have both an institutional tranche and a revolving line of credit are included. The sample period is January 2005 through April 2015. The sample is restricted to loans rated between $\mathrm{BB}+$ and $\mathrm{B}$ - since $93 \%$ of cov-lite loans have a rating within this range. Standard errors are adjusted for clustering by firm and time. $* * *, * *$, and $*$ indicate statistical significance at $1 \%, 5 \%$, and $10 \%$.

Panel A: Matching loans within firm at a similar point in time

\begin{tabular}{|c|c|c|c|c|}
\hline & Exact match: & $\begin{array}{l}\text { Issuer, } \\
\text { launch year }\end{array}$ & Issuer & $\begin{array}{l}\text { Issuer, } \\
\text { rating }\end{array}$ \\
\hline & $\begin{array}{l}\text { Nearest } \\
\text { neighbor: }\end{array}$ & $\begin{array}{l}\text { Deal size, } \\
\text { maturity }\end{array}$ & $\begin{array}{l}\text { Launch } \\
\text { date }\end{array}$ & $\begin{array}{l}\text { Launch } \\
\text { date }\end{array}$ \\
\hline & Restriction: & & $\begin{array}{c}\text { Same or } \\
\text { adjacent } \\
\text { calendar } \\
\text { year }\end{array}$ & $\begin{array}{c}\text { Same or } \\
\text { adjacent } \\
\text { calendar } \\
\text { year }\end{array}$ \\
\hline $\begin{array}{l}\text { ATET } \\
\text { Cov-lite } \\
\text { (z-statistic) }\end{array}$ & & $\begin{array}{c}-83.55^{* * *} \\
(-2.94)\end{array}$ & $\begin{array}{c}-73.43 * * * \\
(-6.99)\end{array}$ & $\begin{array}{c}-76.20 * * * \\
(-5.76)\end{array}$ \\
\hline Observations & & 44 & 300 & 174 \\
\hline
\end{tabular}

Panel B: Spread difference between institutional tranche and revolver

\begin{tabular}{lcccccc}
\hline & \multicolumn{3}{c}{ All sample firms } & & \multicolumn{2}{c}{ Registered firms } \\
\cline { 2 - 4 } \cline { 6 - 7 } & $(1)$ & $(2)$ & $(3)$ & & $(4)$ & $(5)$ \\
\hline Covenant lite loan & 1.800 & $-9.480^{* *}$ & $-13.033^{* * *}$ & & -7.187 & -7.056 \\
& $(0.25)$ & $(-2.38)$ & $(-3.41)$ & & $(-0.91)$ & $(-0.84)$
\end{tabular}

Cov-lite $\mathrm{x}$

registered 


\begin{tabular}{|c|c|c|c|c|c|}
\hline Registered & & & $\begin{array}{l}4.001 \\
(0.79)\end{array}$ & & \\
\hline Ln(Assets) & & & & & $\begin{array}{c}-5.545 * * \\
(-2.03)\end{array}$ \\
\hline Leverage & & & & & $\begin{array}{c}-23.428 * * \\
(-2.58)\end{array}$ \\
\hline Current ratio & & & & & $\begin{array}{l}-1.564 \\
(-0.55)\end{array}$ \\
\hline $\begin{array}{l}\text { Ln(1+Coverage } \\
\text { Ratio) }\end{array}$ & & & & & $\begin{array}{c}-7.416^{* *} \\
(-2.48)\end{array}$ \\
\hline Tangibility & & & & & $\begin{array}{l}-5.126 \\
(-0.39)\end{array}$ \\
\hline Ln(Maturity) & & $\begin{array}{c}-23.068 \\
(-1.64)\end{array}$ & $\begin{array}{c}-22.534 \\
(-1.60)\end{array}$ & $\begin{array}{c}-32.723 \\
(-1.57)\end{array}$ & $\begin{array}{c}-31.996 \\
(-1.51)\end{array}$ \\
\hline Ln(Deal size) & & $\begin{array}{l}-2.470 \\
(-1.54)\end{array}$ & $\begin{array}{c}-3.005^{*} \\
(-1.71)\end{array}$ & $\begin{array}{l}-0.969 \\
(-0.56)\end{array}$ & $\begin{array}{l}3.368 \\
(1.18)\end{array}$ \\
\hline Sponsored & & $\begin{array}{c}-21.642 * * * \\
(-5.79)\end{array}$ & $\begin{array}{c}-20.798 * * * \\
(-5.71)\end{array}$ & $\begin{array}{c}-19.406 * * * \\
(-2.98)\end{array}$ & $\begin{array}{c}-20.083^{* * *} \\
(-3.10)\end{array}$ \\
\hline LBO & & $\begin{array}{l}-0.900 \\
(-0.33)\end{array}$ & $\begin{array}{l}-0.782 \\
(-0.30)\end{array}$ & $\begin{array}{l}-7.327 \\
(-1.24)\end{array}$ & $\begin{array}{l}-5.617 \\
(-0.99)\end{array}$ \\
\hline Bond refinancing & & $\begin{array}{c}-16.815^{* * *} \\
(-3.24)\end{array}$ & $\begin{array}{c}-17.906 * * * \\
(-3.66)\end{array}$ & $\begin{array}{c}-13.664 * * * \\
(-2.64)\end{array}$ & $\begin{array}{c}-13.557 * * \\
(-2.51)\end{array}$ \\
\hline Term loan A & & $\begin{array}{c}29.081^{* * *} \\
(5.67)\end{array}$ & $\begin{array}{c}29.242^{* * *} \\
(5.65)\end{array}$ & $\begin{array}{l}8.513 \\
(1.36)\end{array}$ & $\begin{array}{l}8.489 \\
(1.45)\end{array}$ \\
\hline Asset based loan & & $\begin{array}{c}175.661^{* * *} \\
(6.29)\end{array}$ & $\begin{array}{c}175.380^{* * *} \\
(6.34)\end{array}$ & $\begin{array}{c}172.463^{* * *} \\
(6.29)\end{array}$ & $\begin{array}{c}169.997 * * * \\
\quad(6.29)\end{array}$ \\
\hline Middle market & & $\begin{array}{l}-8.408 \\
(-0.93)\end{array}$ & $\begin{array}{l}-8.411 \\
(-0.92)\end{array}$ & $\begin{array}{l}10.892 \\
(0.96)\end{array}$ & $\begin{array}{l}8.664 \\
(0.77)\end{array}$ \\
\hline Second lien facility & & $\begin{array}{l}-5.558 \\
(-1.19)\end{array}$ & $\begin{array}{l}-4.732 \\
(-1.15)\end{array}$ & $\begin{array}{c}-10.039 * \\
(-1.70)\end{array}$ & $\begin{array}{c}-12.552 * \\
(-1.93)\end{array}$ \\
\hline Ln(Firm age) & & $\begin{array}{l}0.965 \\
(0.98)\end{array}$ & $\begin{array}{l}0.812 \\
(0.79)\end{array}$ & $\begin{array}{l}0.479 \\
(0.18)\end{array}$ & $\begin{array}{l}1.091 \\
(0.42)\end{array}$ \\
\hline Constant & $\begin{array}{l}-3.354 \\
(-0.42)\end{array}$ & $\begin{array}{c}73.905^{* * * *} \\
(2.96)\end{array}$ & $\begin{array}{c}74.844 * * * \\
(2.95)\end{array}$ & $\begin{array}{c}80.631^{* * *} \\
(2.74)\end{array}$ & $\begin{array}{c}119.286 * * * \\
(3.50)\end{array}$ \\
\hline
\end{tabular}




\begin{tabular}{lccccc} 
Rating effects & Yes & Yes & Yes & Yes & Yes \\
Industry effects & Yes & Yes & Yes & Yes & Yes \\
Year effects & Yes & Yes & Yes & Yes & Yes \\
\hline Observations & 2360 & 2239 & 2239 & 958 & 958 \\
\hline
\end{tabular}




\section{Table 6: Comparison of bond and loan liquidity}

This table shows average quoted bid-ask spreads (in basis points) for noncallable bonds, covenant-lite loans, and covenant-heavy loans, respectively. Average quoted spreads for bonds are taken from Chen, Lesmond, and Wei (2007), Table 1, Panel A. These are average bid-ask spreads for bonds of maturity between one and seven years from 1995 through 2003 (although the authors write that most quotes are available only from 2000 onwards). By comparison, the maturity of loans in our sample ranges from one year to seven years and four months. Since Chen, Lesmond, and Wei (2007) compute spreads in basis points vis-à-vis the bid-ask midpoint, we recompute our spreads the same way. For loans, spreads are broken down into average spreads over the first three months, first year, second year and third year after the launch date of the loan. A breakdown of spreads based on years since issuance is not available for bonds. Notice that Chen, Lesmond, and Wei (2007) use up-to-date bond ratings while our LCD data is limited to at-issue ratings. To improve comparability, loans that are priced as distressed - and would have likely been downgraded - during the time period in question are excluded from the analysis. In Panel A, a loan is judged to be distressed if the minimum of the bid-ask midpoint during the time period is below 90 cents per one dollar of principal. In Panel B, loans are excluded if the minimum of the bid-ask midpoint is below 95 cents per one dollar of principal. Note that for a loan with five years to maturity, a drop in price to 90 cents represents a change in yield approximately equivalent to a downgrade from straight BB to B- (priced at LIBOR plus 284 basis points and LIBOR plus 497 basis points, respectively, on average). A drop in price to 95 cents represents a change in yield about equal to a downgrade from straight $\mathrm{BB}$ to $\mathrm{B}+$ (the latter being priced at LIBOR plus 387 basis points on average).

Panel A: Excluding loans priced below 90 cents

\begin{tabular}{|c|c|c|c|c|c|c|c|c|c|}
\hline \multirow[b]{2}{*}{ Rating } & \multirow[t]{2}{*}{ Bonds } & \multicolumn{4}{|c|}{ Covenant-lite loans } & \multicolumn{4}{|c|}{ Covenant-heavy loans } \\
\hline & & $\begin{array}{c}\text { First three } \\
\text { months }\end{array}$ & $1^{\text {st }}$ year & $2^{\text {nd }}$ year & $3^{\text {rd }}$ year & $\begin{array}{c}\text { First three } \\
\text { months }\end{array}$ & $1^{\text {st }}$ year & $2^{\text {nd }}$ year & $3^{\text {rd }}$ year \\
\hline $\mathrm{BB}+$ through BB- & 54.26 & 57.70 & 65.37 & 65.83 & 64.35 & 70.15 & 75.94 & 77.13 & 73.88 \\
\hline B+ through B- & 58.76 & 63.08 & 68.47 & 76.76 & 75.48 & 76.56 & 85.73 & 92.56 & 94.37 \\
\hline Observations BB rated & 178 & 115 & 112 & 96 & 64 & 243 & 249 & 216 & 150 \\
\hline Observations B rated & 72 & 357 & 343 & 271 & 184 & 431 & 432 & 373 & 239 \\
\hline
\end{tabular}


Panel B: Excluding loans priced below 95 cents

\begin{tabular}{|c|c|c|c|c|c|c|c|c|c|}
\hline \multirow[b]{2}{*}{ Rating } & \multirow[t]{2}{*}{ Bonds } & \multicolumn{4}{|c|}{ Covenant-lite loans } & \multicolumn{4}{|c|}{ Covenant-heavy loans } \\
\hline & & $\begin{array}{c}\text { First three } \\
\text { months }\end{array}$ & $1^{\text {st }}$ year & $2^{\text {nd }}$ year & $3^{\text {rd }}$ year & $\begin{array}{c}\text { First three } \\
\text { months }\end{array}$ & $1^{\text {st }}$ year & $2^{\text {nd }}$ year & $3^{\text {rd }}$ year \\
\hline $\mathrm{BB}+$ through BB- & 54.26 & 56.69 & 63.15 & 61.05 & 60.84 & 68.18 & 73.20 & 73.44 & 69.36 \\
\hline B+ through B- & 58.76 & 61.83 & 66.16 & 70.81 & 66.62 & 75.76 & 81.44 & 87.13 & 87.04 \\
\hline Observations BB rated & 178 & 113 & 104 & 87 & 59 & 234 & 224 & 200 & 134 \\
\hline Observations B rated & 72 & 351 & 314 & 231 & 150 & 419 & 383 & 324 & 213 \\
\hline
\end{tabular}




\section{Table 7: Univariate Tests}

This table shows summary statistics for covenant-lite and covenant-heavy loans, respectively, as well as the results from $t$-tests and Wilcoxon ranksum tests for differences between the two groups. The sample includes loans issued by non-financial, non-utility US issuers on the US leveraged loan market from January 1, 2005 through April 30, 2015. Loan data are from Capital IQ LCD and the sample is limited to deals that LCD reported as completed as of May 12, 2015. A loan is defined as covenant-lite if it contains a covenant-lite facility, even if other facilities are present. Maturity and all financial ratios have been winsorized at the $1 \%$ and $99 \%$ levels. $* * *, * *$, and * indicate statistical significance at $1 \%, 5 \%$, and $10 \%$.

\begin{tabular}{|c|c|c|c|c|c|c|c|c|}
\hline & \multirow[b]{2}{*}{ Obs. } & \multicolumn{2}{|c|}{ Covenant-lite } & \multicolumn{3}{|c|}{ Covenant-heavy } & \multirow[b]{2}{*}{$\begin{array}{l}\text { Difference } \\
\text { in means } \\
\text { (t-statistic) }\end{array}$} & \multirow[b]{2}{*}{$\begin{array}{l}\text { Difference } \\
\text { in medians } \\
\text { (z-statistic) }\end{array}$} \\
\hline & & $\begin{array}{l}\text { Mean } \\
\text { (St.dev.) }\end{array}$ & Median & Obs. & $\begin{array}{c}\text { Mean } \\
\text { (St.dev.) }\end{array}$ & Median & & \\
\hline Deal size (million) & 986 & $\begin{array}{c}858.678 \\
(1113.305)\end{array}$ & 520.251 & 4574 & $\begin{array}{c}548.375 \\
(895.656)\end{array}$ & 301.849 & $\begin{array}{l}310.304^{* * *} \\
(8.199)\end{array}$ & $\begin{array}{l}218.401^{* * *} \\
(15.129)\end{array}$ \\
\hline Maturity & 986 & $\begin{array}{c}6.235 \\
(0.889)\end{array}$ & 6.546 & 4346 & $\begin{array}{c}5.481 \\
(1.113)\end{array}$ & 5.650 & $\begin{array}{l}0.755^{* * * *} \\
(22.896)\end{array}$ & $\begin{array}{l}0.896^{* * *} \\
(21.780)\end{array}$ \\
\hline Secured & 525 & $\begin{array}{c}0.992 \\
(0.087)\end{array}$ & 1.000 & 2228 & $\begin{array}{c}0.962 \\
(0.192)\end{array}$ & 1.000 & $\begin{array}{c}0.031^{* * *} \\
(5.492)\end{array}$ & $\begin{array}{c}0.000^{* * * *} \\
(3.558)\end{array}$ \\
\hline Rating & 946 & $\begin{array}{l}5.058 \\
(1.337)\end{array}$ & 5.000 & 2957 & $\begin{array}{l}4.568 \\
(1.622)\end{array}$ & 5.000 & $\begin{array}{c}0.490 * * * \\
(9.293)\end{array}$ & $\begin{array}{c}0.000 * * * \\
(8.953)\end{array}$ \\
\hline Rated & 986 & $\begin{array}{c}0.959 \\
(0.197)\end{array}$ & 1.000 & 4574 & $\begin{array}{c}0.646 \\
(0.478)\end{array}$ & 1.000 & $\begin{array}{l}0.313^{* * *} \\
(33.082)\end{array}$ & $\begin{array}{l}0.000^{* * *} \\
(19.485)\end{array}$ \\
\hline $\begin{array}{l}\text { Traded on secondary } \\
\text { market }\end{array}$ & 986 & $\begin{array}{c}0.901 \\
(0.299)\end{array}$ & 1.000 & 4574 & $\begin{array}{c}0.436 \\
(0.496)\end{array}$ & 0.000 & $\begin{array}{c}0.464 * * * \\
(38.616)\end{array}$ & $\begin{array}{l}1.000 * * * \\
(26.471)\end{array}$ \\
\hline Time-to-break & 886 & $\begin{array}{l}13.788 \\
(7.153)\end{array}$ & 13.000 & 1987 & $\begin{array}{c}19.764 \\
(10.819)\end{array}$ & 19.000 & $\begin{array}{l}-5.977 * * * \\
(-17.499)\end{array}$ & $\begin{array}{r}-6.000 * * * \\
(-16.429)\end{array}$ \\
\hline Break price & 886 & $\begin{array}{l}1.000 \\
(0.010)\end{array}$ & 1.002 & 1989 & $\begin{array}{c}0.999 \\
(0.013)\end{array}$ & 1.002 & $\begin{array}{l}0.001 * * \\
(2.476)\end{array}$ & $\begin{array}{c}0.000 \\
(-0.689)\end{array}$ \\
\hline Break below 99 & 886 & $\begin{array}{c}0.058 \\
(0.233)\end{array}$ & 0.000 & 1989 & $\begin{array}{c}0.127 \\
(0.333)\end{array}$ & 0.000 & $\begin{array}{c}-0.070 * * * \\
(-6.434)\end{array}$ & $\begin{array}{c}0.000 * * * \\
(-5.606)\end{array}$ \\
\hline Initial \# LP Funds & 851 & $\begin{array}{c}5.046 \\
(5.681)\end{array}$ & 3.000 & 2065 & $\begin{array}{l}1.969 \\
(3.343)\end{array}$ & 0.000 & $\begin{array}{c}3.076 * * * \\
(14.777)\end{array}$ & $\begin{array}{c}3.000 * * * \\
(18.569)\end{array}$ \\
\hline $\begin{array}{l}\text { Average \% } \\
\text { principal traded }\end{array}$ & 767 & $\begin{array}{l}1.392 \\
(1.686)\end{array}$ & 0.995 & 1124 & $\begin{array}{c}0.854 \\
(1.188)\end{array}$ & 0.486 & $\begin{array}{c}0.538 * * * \\
(7.641)\end{array}$ & $\begin{array}{l}0.509 * * * \\
(11.052)\end{array}$ \\
\hline
\end{tabular}




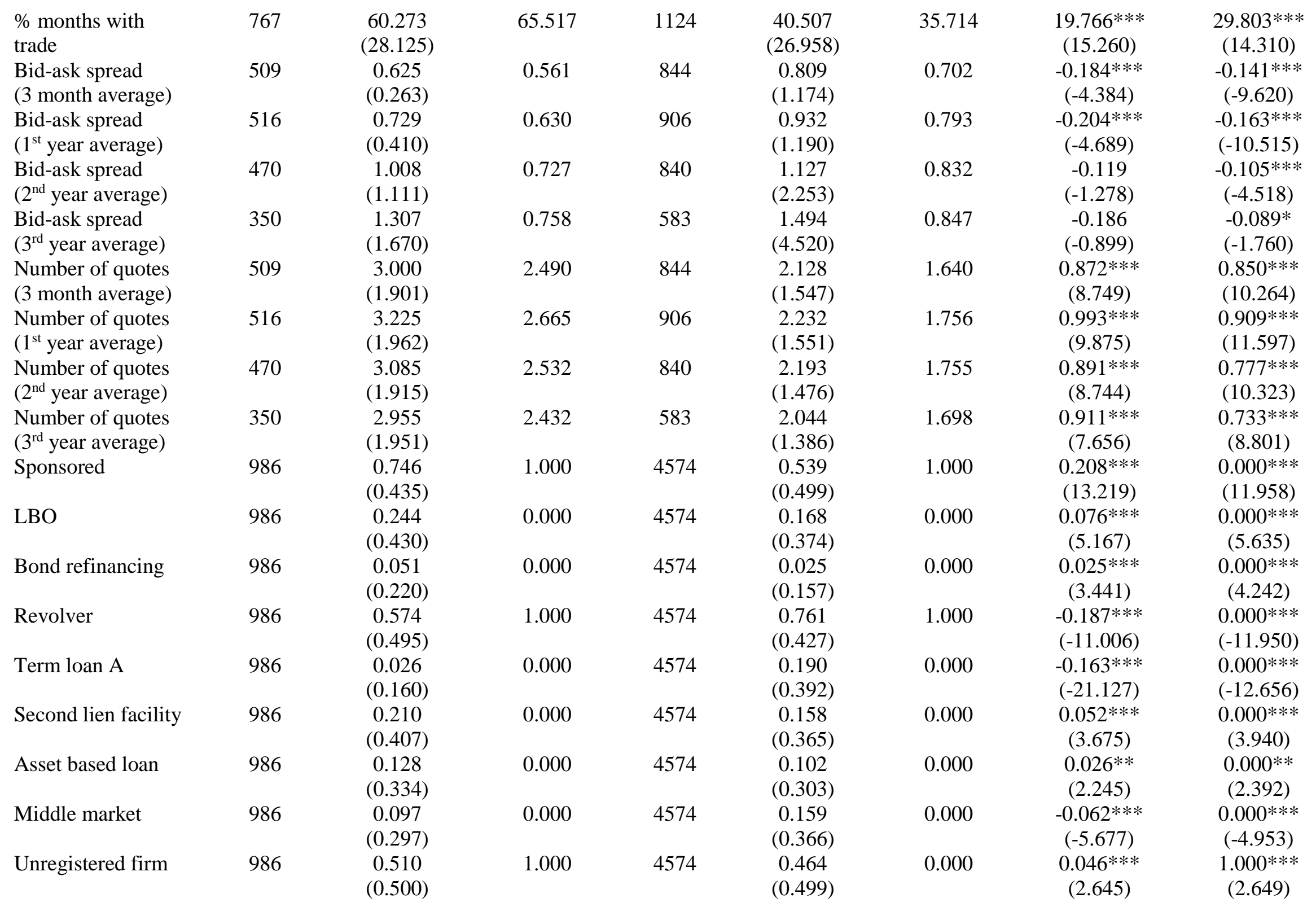




\begin{tabular}{|c|c|c|c|c|c|c|c|c|}
\hline Deregistering firm & 986 & $\begin{array}{c}0.086 \\
(0.281)\end{array}$ & 0.000 & 4574 & $\begin{array}{c}0.051 \\
(0.220)\end{array}$ & 0.000 & $\begin{array}{c}0.035 * * * \\
(3.706)\end{array}$ & $\begin{array}{c}0.000^{* * * *} \\
(4.325)\end{array}$ \\
\hline Firm age & 978 & $\begin{array}{c}45.064 \\
(41.812)\end{array}$ & 30.500 & 4462 & $\begin{array}{c}40.415 \\
(39.238)\end{array}$ & 26.000 & $\begin{array}{c}4.650 * * * \\
(3.184)\end{array}$ & $\begin{array}{c}4.500 * * * \\
(4.246)\end{array}$ \\
\hline Assets (million) & 474 & $\begin{array}{c}13146.794 \\
(117604.779)\end{array}$ & 2184.023 & 2400 & $\begin{array}{c}9999.111 \\
(104071.607)\end{array}$ & 1286.036 & $\begin{array}{c}3147.683 \\
(0.542)\end{array}$ & $\begin{array}{c}897.986 * * * \\
(7.579)\end{array}$ \\
\hline Leverage & 474 & $\begin{array}{c}0.466 \\
(0.288)\end{array}$ & 0.462 & 2395 & $\begin{array}{c}0.423 \\
(0.290)\end{array}$ & 0.394 & $\begin{array}{c}0.043^{* * * *} \\
(2.964)\end{array}$ & $\begin{array}{c}0.069 * * * \\
(3.649)\end{array}$ \\
\hline Current ratio & 480 & $\begin{array}{c}1.989 \\
(1.408)\end{array}$ & 1.614 & 2420 & $\begin{array}{c}1.824 \\
(1.368)\end{array}$ & 1.520 & $\begin{array}{c}0.165^{* *} \\
(2.356)\end{array}$ & $\begin{array}{c}0.094 * * * \\
(3.144)\end{array}$ \\
\hline Profitability & 469 & $\begin{array}{c}0.123 \\
(0.079)\end{array}$ & 0.110 & 2383 & $\begin{array}{c}0.127 \\
(0.081)\end{array}$ & 0.118 & $\begin{array}{c}-0.005 \\
(-1.128)\end{array}$ & $\begin{array}{l}-0.008^{* *} \\
(-2.213)\end{array}$ \\
\hline Tangibility & 473 & $\begin{array}{c}0.248 \\
(0.223) \\
\end{array}$ & 0.163 & 2390 & $\begin{array}{c}0.293 \\
(0.249) \\
\end{array}$ & 0.217 & $\begin{array}{c}-0.045^{* * * *} \\
(-3.919) \\
\end{array}$ & $\begin{array}{c}-0.054^{* * *} \\
(-3.338) \\
\end{array}$ \\
\hline
\end{tabular}




\section{Table 8: Covenant-lite loans and SEC registration}

This table reports average marginal effects from probit regressions examining the relation between covenant-lite loans and SEC registration and deregistration for the leveraged loan sample. We proxy for SEC registration by checking whether the borrower has data on total assets available in either Compustat or Capital IQ. If the data source is Capital IQ, we check that the data come from an SEC filing and not a non-SEC report. Columns (1) through (3) assess whether issuers of cov-lite loans are more likely to deregister subsequent to loan origination. Only firms that have asset data available at the end of the fiscal year prior to loan origination are included in these regressions. Deregistered ${ }_{t+1}$ equals one if asset data are unavailable at the end of the fiscal year during which the loan is originated and zero if asset data continue to be available. Firms that disappear due to bankruptcy or a merger are coded as zero. Column (4) includes all loans and assesses whether unregistered firms and firms that are about to deregister are more likely to issue covenant-lite loans. In column (4) firms are classified as deregistering if they deregister within three years after loan origination. The sample period is January 2005 through April 2015. Standard errors are adjusted for clustering by firm and time. ${ }^{* * *}$, **, and * indicate statistical significance at $1 \%, 5 \%$, and $10 \%$.

Deregistration

(1)

Deregistered $_{\mathrm{t}+1}$

Covenant lite loan

LBO x cov-lite

Unregistered firm

Deregistering firm

Ln(Maturity)

Ln(Deal size)

Sponsored

LBO

Bond refinancing

$$
\text { (4.21) }
$$

$-0.032 * *$
(2) Deregistered $_{\mathrm{t}+2}$ $0.046^{* *}$
$(2.91)$

$-0.017$ $(-0.73)$
Cov-lite vs. cov-heavy

(4)
(3) Deregistered $_{\mathrm{t}+3}$ $0.058^{* * *}$
(3.19) $(-0.20)$

Cov-lite 


\begin{tabular}{|c|c|c|c|c|}
\hline Revolver & $\begin{array}{l}0.017 \\
(1.49)\end{array}$ & $\begin{array}{c}0.026^{* *} \\
(2.45)\end{array}$ & $\begin{array}{l}0.002 \\
(0.13)\end{array}$ & $\begin{array}{c}-0.107 * * * \\
(-8.31)\end{array}$ \\
\hline Term loan A & $\begin{array}{l}-0.012 \\
(-0.76)\end{array}$ & $\begin{array}{l}-0.019 \\
(-0.98)\end{array}$ & $\begin{array}{l}-0.020 \\
(-0.88)\end{array}$ & $\begin{array}{c}-0.141^{* * *} \\
(-8.01)\end{array}$ \\
\hline Asset based loan & $\begin{array}{l}0.009 \\
(0.91)\end{array}$ & $\begin{array}{l}0.013 \\
(0.99)\end{array}$ & $\begin{array}{c}0.033^{* * *} \\
(2.92)\end{array}$ & $\begin{array}{l}0.047^{*} \\
(1.85)\end{array}$ \\
\hline Middle market & $\begin{array}{c}0.012 \\
(1.11)\end{array}$ & $\begin{array}{c}0.045^{* * *} \\
(2.80)\end{array}$ & $\begin{array}{c}0.064^{* * *} \\
(3.17)\end{array}$ & $\begin{array}{c}-0.102 * * * \\
(-5.90)\end{array}$ \\
\hline Second lien facility & $\begin{array}{c}0.072 * * * \\
(6.26)\end{array}$ & $\begin{array}{c}0.091 * * * \\
(5.95)\end{array}$ & $\begin{array}{c}0.103^{* * *} \\
(5.94)\end{array}$ & $\begin{array}{c}-0.052 * * * \\
(-5.75)\end{array}$ \\
\hline Ln(Firm age) & $\begin{array}{l}-0.005 \\
(-1.11)\end{array}$ & $\begin{array}{l}-0.002 \\
(-0.54)\end{array}$ & $\begin{array}{l}-0.005 \\
(-0.84)\end{array}$ & $\begin{array}{l}0.006 \\
(1.07)\end{array}$ \\
\hline Prevailing \% cov- lite & & & & $\begin{array}{c}0.685^{* * *} \\
(18.76)\end{array}$ \\
\hline $\begin{array}{l}\text { Fed net \% } \\
\text { tightening }\end{array}$ & & & & $\begin{array}{l}0.000 \\
(0.42)\end{array}$ \\
\hline Rating effects & Yes & Yes & Yes & Yes \\
\hline Industry effects & Yes & Yes & Yes & Yes \\
\hline Year effects & Yes & Yes & Yes & No \\
\hline Observations & 2809 & 2809 & 2809 & 5204 \\
\hline
\end{tabular}




\section{Table 9: Are covenant-lite loans more likely to trade?}

This table reports average marginal effects from probit regressions predicting whether a loan trades on the secondary market. The dependent variable equals one if LCD records a break price for the loan, indicating that the loan broke into secondary market trading. The sample period is January 2005 through April 2015. Standard errors are adjusted for clustering by firm and time. ${ }^{* * *}, * *$, and $*$ indicate statistical significance at $1 \%, 5 \%$, and $10 \%$.

\begin{tabular}{|c|c|c|c|c|c|}
\hline & \multicolumn{2}{|c|}{ All firms } & \multirow{2}{*}{$\begin{array}{c}\text { Rated } \\
\text { firms }\end{array}$} & \multicolumn{2}{|c|}{ Registered firms } \\
\hline & (1) & $(2)$ & & (4) & (5) \\
\hline $\begin{array}{l}\text { Covenant lite } \\
\text { loan }\end{array}$ & $\begin{array}{l}0.159^{* * *} \\
\quad(6.46)\end{array}$ & $\begin{array}{c}0.102^{* * *} \\
(6.43)\end{array}$ & $\begin{array}{c}0.171^{* * *} \\
(6.36)\end{array}$ & $\begin{array}{c}0.236^{* * *} \\
(5.39)\end{array}$ & $\begin{array}{c}0.232^{* * *} \\
(5.61)\end{array}$ \\
\hline $\begin{array}{l}\text { Covenant lite } \\
\text { x Registered }\end{array}$ & & $\begin{array}{c}0.116^{* * * *} \\
(3.21)\end{array}$ & & & \\
\hline Registered & & $\begin{array}{c}-0.078 * * * \\
(-7.16)\end{array}$ & & & \\
\hline Ln(Assets) & & & & & $\begin{array}{c}-0.037 * * * \\
(-2.88)\end{array}$ \\
\hline Leverage & & & & & $\begin{array}{l}0.001 \\
(0.04)\end{array}$ \\
\hline Current ratio & & & & & $\begin{array}{l}-0.003 \\
(-0.50)\end{array}$ \\
\hline $\begin{array}{l}\text { Ln(1+Coverage } \\
\text { Ratio) }\end{array}$ & & & & & $\begin{array}{l}0.004 \\
(0.28)\end{array}$ \\
\hline Tangibility & & & & & $\begin{array}{l}-0.078 * \\
(-1.90)\end{array}$ \\
\hline Ln(Maturity) & $\begin{array}{c}0.169 * * * \\
(4.79)\end{array}$ & $\begin{array}{c}0.159 * * * \\
(4.45)\end{array}$ & $\begin{array}{c}0.243^{* * *} \\
(4.77)\end{array}$ & $\begin{array}{c}0.160^{* * *} \\
(3.31)\end{array}$ & $\begin{array}{c}0.128^{* * *} \\
(2.79)\end{array}$ \\
\hline Ln(Deal size) & $\begin{array}{c}0.171^{* * *} \\
(16.25)\end{array}$ & $\begin{array}{c}0.175^{* * *} \\
(17.06)\end{array}$ & $\begin{array}{c}0.180 * * * \\
(16.87)\end{array}$ & $\begin{array}{c}0.161^{* * *} \\
(16.78)\end{array}$ & $\begin{array}{c}0.185^{* * *} \\
(12.91)\end{array}$ \\
\hline Sponsored & $\begin{array}{c}0.083^{* * *} \\
(7.52)\end{array}$ & $\begin{array}{c}0.066^{* * *} \\
(5.76)\end{array}$ & $\begin{array}{c}0.057 * * * \\
(4.35)\end{array}$ & $\begin{array}{c}0.044^{* * *} \\
(3.01)\end{array}$ & $\begin{array}{c}0.039 * * \\
(2.25)\end{array}$ \\
\hline LBO & $\begin{array}{l}0.021 \\
(1.13)\end{array}$ & $\begin{array}{l}0.020 \\
(1.07)\end{array}$ & $\begin{array}{l}0.034 \\
(1.17)\end{array}$ & $\begin{array}{l}0.018 \\
(0.94)\end{array}$ & $\begin{array}{l}0.016 \\
(0.73)\end{array}$ \\
\hline
\end{tabular}




\begin{tabular}{|c|c|c|c|c|c|}
\hline $\begin{array}{l}\text { Bond } \\
\text { refinancing }\end{array}$ & $\begin{array}{l}0.045 \\
(1.38)\end{array}$ & $\begin{array}{l}0.054^{*} \\
(1.65)\end{array}$ & $\begin{array}{l}0.049 \\
(1.62)\end{array}$ & $\begin{array}{c}0.053 \\
(1.62)\end{array}$ & $\begin{array}{c}0.061^{* *} \\
(1.97)\end{array}$ \\
\hline Revolver & $\begin{array}{c}-0.106^{* * *} \\
(-17.30)\end{array}$ & $\begin{array}{c}-0.112 * * * \\
(-23.22)\end{array}$ & $\begin{array}{c}-0.111^{* * *} \\
(-16.40)\end{array}$ & $\begin{array}{c}-0.136 * * * \\
(-7.35)\end{array}$ & $\begin{array}{c}-0.164 * * * \\
(-7.85)\end{array}$ \\
\hline Term loan A & $\begin{array}{c}-0.250 * * * \\
(-11.90)\end{array}$ & $\begin{array}{c}-0.242 * * * \\
(-11.29)\end{array}$ & $\begin{array}{c}-0.239 * * * \\
(-10.26)\end{array}$ & $\begin{array}{c}-0.220 * * * \\
(-11.24)\end{array}$ & $\begin{array}{c}-0.229 * * * \\
(-11.95)\end{array}$ \\
\hline Asset based loan & $\begin{array}{c}-0.120^{* * * *} \\
(-4.12)\end{array}$ & $\begin{array}{c}-0.114^{* * *} \\
(-4.09)\end{array}$ & $\begin{array}{c}-0.130 * * * \\
(-5.06)\end{array}$ & $\begin{array}{c}-0.122 * * * \\
(-3.35)\end{array}$ & $\begin{array}{c}-0.116 * * * \\
(-3.38)\end{array}$ \\
\hline Middle market & $\begin{array}{l}0.006 \\
(0.30)\end{array}$ & $\begin{array}{l}-0.004 \\
(-0.18)\end{array}$ & $\begin{array}{l}0.031 \\
(1.59)\end{array}$ & $\begin{array}{c}0.094^{* * *} \\
(5.11)\end{array}$ & $\begin{array}{c}0.069 * * * \\
(3.23)\end{array}$ \\
\hline $\begin{array}{l}\text { Second lien } \\
\text { facility }\end{array}$ & $\begin{array}{c}-0.043^{* * * *} \\
(-3.16)\end{array}$ & $\begin{array}{c}-0.052 * * * \\
(-4.00)\end{array}$ & $\begin{array}{c}-0.068 * * * \\
(-3.22)\end{array}$ & $\begin{array}{c}-0.063 * * \\
(-2.33)\end{array}$ & $\begin{array}{c}-0.072 * * \\
(-2.52)\end{array}$ \\
\hline Ln(Firm age) & $\begin{array}{l}-0.007 \\
(-0.71)\end{array}$ & $\begin{array}{l}-0.004 \\
(-0.43)\end{array}$ & $\begin{array}{l}-0.009 \\
(-0.86)\end{array}$ & $\begin{array}{l}-0.010 \\
(-0.60)\end{array}$ & $\begin{array}{l}-0.004 \\
(-0.27)\end{array}$ \\
\hline Rating effects & Yes & Yes & Yes & Yes & Yes \\
\hline Year effects & Yes & Yes & Yes & Yes & Yes \\
\hline Industry effects & Yes & Yes & Yes & Yes & Yes \\
\hline Observations & 5205 & 5205 & 3800 & 2558 & 2558 \\
\hline
\end{tabular}




\section{Table 10: Do covenant-lite loans break into secondary market trading more quickly?}

The dependent variable is time-to-break, the number of days between the launch date of the loan and the first day on which the loan is traded in the loan trading market. The average is 17 days. The sample period is January 2005 through April 2015. Standard errors are adjusted for clustering by firm and time. ***, **, and $*$ indicate statistical significance at $1 \%, 5 \%$, and $10 \%$.

\begin{tabular}{|c|c|c|c|c|c|}
\hline & \multicolumn{2}{|c|}{ All firms } & \multirow{2}{*}{$\begin{array}{c}\text { Rated firms } \\
\text { (3) }\end{array}$} & \multicolumn{2}{|c|}{ Registered firms } \\
\hline & (1) & $(2)$ & & (4) & (5) \\
\hline $\begin{array}{l}\text { Covenant lite } \\
\text { loan }\end{array}$ & $\begin{array}{c}-1.2707 * * * \\
(-3.60)\end{array}$ & $\begin{array}{c}-1.9987 * * * \\
(-4.25)\end{array}$ & $\begin{array}{c}-1.3860 * * * \\
(-3.97)\end{array}$ & $\begin{array}{l}-0.6723 \\
(-1.30)\end{array}$ & $\begin{array}{l}-0.6397 \\
(-1.11)\end{array}$ \\
\hline $\begin{array}{l}\text { Covenant lite } \\
\text { x Registered }\end{array}$ & & $\begin{array}{l}1.4540 \\
(1.64)\end{array}$ & & & \\
\hline Registered & & $\begin{array}{c}-1.9065 * * \\
(-2.52)\end{array}$ & & & \\
\hline Ln(Assets) & & & & & $\begin{array}{c}-1.5049 * * * \\
(-3.94)\end{array}$ \\
\hline Leverage & & & & & $\begin{array}{c}-3.5636^{* * *} \\
(-4.46)\end{array}$ \\
\hline Current ratio & & & & & $\begin{array}{c}-0.0939 \\
(-0.42)\end{array}$ \\
\hline $\begin{array}{l}\text { Ln(1+Coverage } \\
\text { Ratio) }\end{array}$ & & & & & $\begin{array}{l}0.0322 \\
(0.12)\end{array}$ \\
\hline Tangibility & & & & & $\begin{array}{l}1.4118 \\
(1.17)\end{array}$ \\
\hline Ln(Maturity) & $\begin{array}{c}1.2756^{*} \\
(1.89)\end{array}$ & $\begin{array}{c}1.1702 * \\
(1.76)\end{array}$ & $\begin{array}{l}0.5757 \\
(1.02)\end{array}$ & $\begin{array}{c}2.6337 * * * \\
(2.94)\end{array}$ & $\begin{array}{l}1.4148 \\
(1.58)\end{array}$ \\
\hline Ln(Deal size) & $\begin{array}{c}-0.8337 * * \\
(-2.44)\end{array}$ & $\begin{array}{c}-0.6701^{* *} \\
(-2.04)\end{array}$ & $\begin{array}{c}-0.8111^{* *} \\
(-2.45)\end{array}$ & $\begin{array}{c}-0.8252 * * \\
(-2.26)\end{array}$ & $\begin{array}{l}0.3268 \\
(0.90)\end{array}$ \\
\hline Sponsored & $\begin{array}{c}-1.7040 * * * \\
(-2.98)\end{array}$ & $\begin{array}{c}-2.0534 * * * \\
(-3.69)\end{array}$ & $\begin{array}{c}-1.5538 * * * \\
(-3.12)\end{array}$ & $\begin{array}{c}-1.9749 * * * \\
(-3.27)\end{array}$ & $\begin{array}{c}-1.5589 * * \\
(-2.48)\end{array}$ \\
\hline LBO & $\begin{array}{c}-1.2287 * * \\
(-2.26)\end{array}$ & $\begin{array}{c}-1.2380 * * \\
(-2.15)\end{array}$ & $\begin{array}{c}-1.2681^{* *} \\
(-2.28)\end{array}$ & $\begin{array}{c}-1.3714 \\
(-1.41)\end{array}$ & $\begin{array}{c}-2.1725^{* *} \\
(-2.36)\end{array}$ \\
\hline $\begin{array}{l}\text { Bond } \\
\text { refinancing }\end{array}$ & $\begin{array}{c}-2.3254^{* * *} \\
(-2.93)\end{array}$ & $\begin{array}{c}-2.1291 * * * \\
(-2.71)\end{array}$ & $\begin{array}{c}-1.9581 * * * \\
(-3.00)\end{array}$ & $\begin{array}{c}-2.1911^{* *} \\
(-2.05)\end{array}$ & $\begin{array}{c}-1.8450 * * \\
(-2.05)\end{array}$ \\
\hline
\end{tabular}




\begin{tabular}{lccccc} 
Revolver & $\begin{array}{c}4.6006^{* * *} \\
(7.91)\end{array}$ & $\begin{array}{c}4.3732^{* * *} \\
(7.54)\end{array}$ & $\begin{array}{c}5.1098^{* * *} \\
(10.24)\end{array}$ & $\begin{array}{c}3.6367^{* * *} \\
(7.11)\end{array}$ & $\begin{array}{c}2.2905^{* * *} \\
(3.56)\end{array}$ \\
Term loan A & $\begin{array}{c}3.1981^{* * *} \\
(3.10)\end{array}$ & $\begin{array}{c}3.2931^{* * *} \\
(3.09)\end{array}$ & $\begin{array}{c}2.5944^{* * *} \\
(2.66)\end{array}$ & $\begin{array}{c}3.0586^{* * *} \\
(3.32)\end{array}$ & $\begin{array}{c}2.8839^{* * *} \\
(3.00)\end{array}$ \\
Asset based loan & $\begin{array}{c}2.3840^{* *} \\
(1.98)\end{array}$ & $\begin{array}{c}2.4777^{* *} \\
(2.03)\end{array}$ & $\begin{array}{c}1.9625^{* *} \\
(2.06)\end{array}$ & $\begin{array}{c}3.7607^{* *} \\
(2.31)\end{array}$ & $\begin{array}{c}3.4367^{* *} \\
(2.26)\end{array}$ \\
Middle market & $\begin{array}{c}4.6844^{* * *} \\
(9.49)\end{array}$ & $\begin{array}{c}4.5397^{* * *} \\
(8.98)\end{array}$ & $\begin{array}{c}4.4691^{* * *} \\
(7.43)\end{array}$ & $\begin{array}{c}4.6854^{* * *} \\
(7.82)\end{array}$ & $\begin{array}{c}3.5745^{* * *} \\
(4.14)\end{array}$ \\
Second lien & $2.3514^{* * *}$ & $2.0933^{* * *}$ & $2.6415^{* * *}$ & $2.0701^{* * *}$ & $1.6985^{* *}$ \\
facility & $(3.45)$ & $(3.29)$ & $(4.04)$ & $(2.62)$ & $(1.97)$ \\
Ln(Firm age) & $-0.4622^{* *}$ & $-0.4010^{* *}$ & $-0.4368^{* *}$ & -0.2272 & -0.0392 \\
& $(-2.43)$ & $(-2.04)$ & $(-2.11)$ & $(-1.13)$ & $(-0.22)$ \\
Constant & $28.5964^{* * *}$ & $28.7426 * * *$ & $25.5092^{* * *}$ & $32.2186^{* * *}$ & $40.4436^{* * *}$ \\
& $(10.47)$ & $(10.98)$ & $(5.97)$ & $(6.57)$ & $(8.28)$ \\
Rating effects & Yes & Yes & Yes & Yes & Yes \\
Year effects & Yes & Yes & Yes & Yes & Yes \\
Industry effects & Yes & Yes & Yes & Yes & Yes \\
\hline Observations & 2823 & 2823 & 2572 & 1367 & 1367 \\
\hline
\end{tabular}




\section{Table 11: Are break prices different for covenant-lite loans?}

Break price is the price at which the loan starts trading in the secondary market, as reported by LCD. Break below 99 indicates that the loan's break price is lower than 99 cents on the dollar, which is the $10^{\text {th }}$ percentile of the break price distribution. Columns (1) through (5) report results from OLS regressions and columns (6) through (10) report average marginal effects from probit regressions. The sample period is January 2005 through April 2015. Standard errors are adjusted for clustering by firm and time. ***, **, and * indicate statistical significance at $1 \%$, 5\%, and $10 \%$.

\begin{tabular}{|c|c|c|c|c|c|c|c|c|c|c|}
\hline \multirow[t]{3}{*}{ Dep. variable: } & \multicolumn{5}{|c|}{ Break price } & \multicolumn{5}{|c|}{ Break below 99} \\
\hline & \multicolumn{2}{|c|}{ All firms } & \multirow{2}{*}{$\begin{array}{l}\text { Rated firms } \\
\text { (3) }\end{array}$} & \multicolumn{2}{|c|}{ Registered firms } & \multicolumn{2}{|c|}{ All firms } & \multirow{3}{*}{$\begin{array}{c}\text { Rated firms } \\
\quad(8) \\
-0.0791^{* * *} \\
(-6.01)\end{array}$} & \multicolumn{2}{|c|}{ Registered firms } \\
\hline & (1) & (2) & & (4) & (5) & (6) & (7) & & (9) & (10) \\
\hline $\begin{array}{l}\text { Covenant lite } \\
\text { loan }\end{array}$ & $\begin{array}{c}0.0024^{* * *} \\
(3.05)\end{array}$ & $\begin{array}{l}0.0033^{* * *} \\
(5.18)\end{array}$ & $\begin{array}{c}0.0024^{* * *} \\
(2.81)\end{array}$ & $\begin{array}{l}0.0021^{*} \\
(1.92)\end{array}$ & $\begin{array}{c}0.0022^{*} \\
(1.87)\end{array}$ & $\begin{array}{c}-0.0819 * * * \\
(-6.28)\end{array}$ & $\begin{array}{c}-0.0926 * * * \\
(-8.23)\end{array}$ & & $\begin{array}{c}-0.0515^{* * *} \\
(-3.64)\end{array}$ & $\begin{array}{c}-0.0528^{* * *} \\
(-4.03)\end{array}$ \\
\hline $\begin{array}{l}\text { Covenant lite } \\
\text { x Registered }\end{array}$ & & $\begin{array}{c}-0.0017^{*} \\
(-1.86)\end{array}$ & & & & & $\begin{array}{l}0.0221^{* *} \\
(2.16)\end{array}$ & & & \\
\hline Registered & & $\begin{array}{l}0.0001 \\
(0.09)\end{array}$ & & & & & $\begin{array}{l}0.0007 \\
(0.05)\end{array}$ & & & \\
\hline Ln(Assets) & & & & & $\begin{array}{c}-0.0000 \\
(-0.21)\end{array}$ & & & & & $\begin{array}{l}0.0094^{*} \\
(1.70)\end{array}$ \\
\hline Leverage & & & & & $\begin{array}{l}0.0017 \\
(1.52)\end{array}$ & & & & & $\begin{array}{l}-0.0365 \\
(-1.24)\end{array}$ \\
\hline Current ratio & & & & & $\begin{array}{c}-0.0002 \\
(-0.66)\end{array}$ & & & & & $\begin{array}{l}0.0038 \\
(0.68)\end{array}$ \\
\hline $\begin{array}{l}\text { Ln(1+Coverage } \\
\text { Ratio) }\end{array}$ & & & & & $\begin{array}{l}0.0001 \\
(0.26)\end{array}$ & & & & & $\begin{array}{l}-0.0016 \\
(-0.18)\end{array}$ \\
\hline Tangibility & & & & & $\begin{array}{c}-0.0012 \\
(-0.78)\end{array}$ & & & & & $\begin{array}{c}0.0542 * * \\
(2.49)\end{array}$ \\
\hline Ln(Maturity) & $\begin{array}{c}-0.0007 \\
(-0.35)\end{array}$ & $\begin{array}{c}-0.0007 \\
(-0.39)\end{array}$ & $\begin{array}{c}-0.0000 \\
(-0.02)\end{array}$ & $\begin{array}{c}-0.0009 \\
(-0.50)\end{array}$ & $\begin{array}{c}-0.0008 \\
(-0.50)\end{array}$ & $\begin{array}{c}-0.0257 \\
(-0.86)\end{array}$ & $\begin{array}{c}-0.0245 \\
(-0.82)\end{array}$ & $\begin{array}{c}-0.0680 * * * \\
(-2.92)\end{array}$ & $\begin{array}{c}-0.0303 \\
(-0.97)\end{array}$ & $\begin{array}{l}-0.0265 \\
(-0.92)\end{array}$ \\
\hline Ln(Deal size) & 0.0002 & 0.0003 & 0.0002 & -0.0002 & -0.0002 & -0.0091 & -0.0098 & -0.0076 & -0.0004 & -0.0062 \\
\hline
\end{tabular}




\begin{tabular}{|c|c|c|c|c|c|c|c|c|c|c|}
\hline & $(0.60)$ & $(0.73)$ & $(0.41)$ & $(-0.52)$ & $(-0.55)$ & $(-0.70)$ & $(-0.77)$ & $(-0.61)$ & $(-0.03)$ & $(-0.58)$ \\
\hline Sponsored & $\begin{array}{c}0.0006 \\
(0.70)\end{array}$ & $\begin{array}{c}0.0006 \\
(0.71)\end{array}$ & $\begin{array}{c}0.0006 \\
(0.68)\end{array}$ & $\begin{array}{c}0.0006 \\
(0.71)\end{array}$ & $\begin{array}{c}0.0004 \\
(0.44)\end{array}$ & $\begin{array}{c}-0.0119 \\
(-0.62)\end{array}$ & $\begin{array}{c}-0.0114 \\
(-0.59)\end{array}$ & $\begin{array}{c}-0.0026 \\
(-0.13)\end{array}$ & $\begin{array}{c}-0.0053 \\
(-0.29)\end{array}$ & $\begin{array}{c}-0.0002 \\
(-0.01)\end{array}$ \\
\hline LBO & $\begin{array}{c}-0.0021 \\
(-1.52)\end{array}$ & $\begin{array}{c}-0.0021 \\
(-1.56)\end{array}$ & $\begin{array}{c}-0.0018^{*} \\
(-1.66)\end{array}$ & $\begin{array}{c}-0.0023 \\
(-1.57)\end{array}$ & $\begin{array}{c}-0.0021 \\
(-1.51)\end{array}$ & $\begin{array}{c}0.0564 * * * \\
(3.15)\end{array}$ & $\begin{array}{c}0.0568 * * * \\
(3.22)\end{array}$ & $\begin{array}{l}0.0543^{* * *} \\
(3.38)\end{array}$ & $\begin{array}{c}0.0599 * * * \\
(2.61)\end{array}$ & $\begin{array}{c}0.0541^{* *} \\
(2.26)\end{array}$ \\
\hline $\begin{array}{l}\text { Bond } \\
\text { refinancing }\end{array}$ & $\begin{array}{l}-0.0016 \\
(-1.16)\end{array}$ & $\begin{array}{l}-0.0014 \\
(-1.01)\end{array}$ & $\begin{array}{l}-0.0015 \\
(-1.12)\end{array}$ & $\begin{array}{c}-0.0022 \\
(-1.25)\end{array}$ & $\begin{array}{l}-0.0023 \\
(-1.36)\end{array}$ & $\begin{array}{c}0.0287 \\
(1.38)\end{array}$ & $\begin{array}{c}0.0256 \\
(1.30)\end{array}$ & $\begin{array}{c}0.0322 \\
(1.54)\end{array}$ & $\begin{array}{c}0.0383 \\
(1.64)\end{array}$ & $\begin{array}{c}0.0356^{*} \\
(1.91)\end{array}$ \\
\hline Revolver & $\begin{array}{c}-0.0001 \\
(-0.13)\end{array}$ & $\begin{array}{c}-0.0001 \\
(-0.17)\end{array}$ & $\begin{array}{c}-0.0003 \\
(-0.45)\end{array}$ & $\begin{array}{c}-0.0004 \\
(-0.39)\end{array}$ & $\begin{array}{c}-0.0004 \\
(-0.39)\end{array}$ & $\begin{array}{c}-0.0134 \\
(-0.82)\end{array}$ & $\begin{array}{c}-0.0126 \\
(-0.80)\end{array}$ & $\begin{array}{c}-0.0091 \\
(-0.56)\end{array}$ & $\begin{array}{c}-0.0222 \\
(-1.51)\end{array}$ & $\begin{array}{c}-0.0132 \\
(-1.04)\end{array}$ \\
\hline Term loan A & $\begin{array}{c}0.0018 * \\
(1.89)\end{array}$ & $\begin{array}{c}0.0018 * \\
(1.79)\end{array}$ & $\begin{array}{c}0.0020^{* *} \\
(2.11)\end{array}$ & $\begin{array}{c}0.0022 * * * \\
(2.62)\end{array}$ & $\begin{array}{c}0.0021 * * \\
(2.45)\end{array}$ & $\begin{array}{c}-0.0265 \\
(-0.77)\end{array}$ & $\begin{array}{l}-0.0260 \\
(-0.75)\end{array}$ & $\begin{array}{c}-0.0281 \\
(-0.72)\end{array}$ & $\begin{array}{c}-0.0334 \\
(-1.34)\end{array}$ & $\begin{array}{c}-0.0285 \\
(-1.19)\end{array}$ \\
\hline $\begin{array}{l}\text { Asset based } \\
\text { loan }\end{array}$ & $\begin{array}{c}-0.0030 * * * \\
(-3.01)\end{array}$ & $\begin{array}{c}-0.0030 * * * \\
(-2.95)\end{array}$ & $\begin{array}{c}-0.0029 * * * \\
(-2.80)\end{array}$ & $\begin{array}{c}-0.0032^{* *} \\
(-2.20)\end{array}$ & $\begin{array}{c}-0.0031^{* *} \\
(-2.11)\end{array}$ & $\begin{array}{l}0.0519 * * * \\
(5.11)\end{array}$ & $\begin{array}{c}0.0518^{* * * *} \\
(5.09)\end{array}$ & $\begin{array}{l}0.0512 * * * \\
\quad(6.70)\end{array}$ & $\begin{array}{c}0.0561 * * * \\
(4.74)\end{array}$ & $\begin{array}{c}0.0542^{* * *} \\
\quad(4.50)\end{array}$ \\
\hline Middle market & $\begin{array}{c}-0.0018^{* *} \\
(-2.23)\end{array}$ & $\begin{array}{c}-0.0017^{* *} \\
(-2.15)\end{array}$ & $\begin{array}{c}-0.0020 * \\
(-1.95)\end{array}$ & $\begin{array}{c}-0.0041^{* * *} \\
(-3.11)\end{array}$ & $\begin{array}{c}-0.0039 * * * \\
(-2.96)\end{array}$ & $\begin{array}{c}0.0194 \\
(1.15)\end{array}$ & $\begin{array}{c}0.0181 \\
(1.09)\end{array}$ & $\begin{array}{c}0.0165 \\
(0.81)\end{array}$ & $\begin{array}{c}0.0871 * * * \\
(7.15)\end{array}$ & $\begin{array}{c}0.0895^{* * *} \\
\quad(6.69)\end{array}$ \\
\hline $\begin{array}{l}\text { Second lien } \\
\text { facility }\end{array}$ & $\begin{array}{c}0.0002 \\
(0.45)\end{array}$ & $\begin{array}{c}0.0000 \\
(0.09)\end{array}$ & $\begin{array}{c}0.0001 \\
(0.14)\end{array}$ & $\begin{array}{c}0.0012 \\
(1.02)\end{array}$ & $\begin{array}{c}0.0010 \\
(0.89)\end{array}$ & $\begin{array}{c}0.0099 \\
(0.55)\end{array}$ & $\begin{array}{c}0.0121 \\
(0.67)\end{array}$ & $\begin{array}{c}0.0150 \\
(0.78)\end{array}$ & $\begin{array}{c}-0.0310 \\
(-1.22)\end{array}$ & $\begin{array}{c}-0.0268 \\
(-1.07)\end{array}$ \\
\hline Ln(Firm age) & $\begin{array}{c}0.0005 * \\
(1.95)\end{array}$ & $\begin{array}{c}0.0005^{* *} \\
(2.03)\end{array}$ & $\begin{array}{c}0.0003 \\
(1.58)\end{array}$ & $\begin{array}{c}0.0002 \\
(1.01)\end{array}$ & $\begin{array}{c}0.0002 \\
(1.18)\end{array}$ & $\begin{array}{c}-0.0125 * * \\
(-2.57)\end{array}$ & $\begin{array}{c}-0.0127 * * * \\
(-2.60)\end{array}$ & $\begin{array}{c}-0.0081 \\
(-1.23)\end{array}$ & $\begin{array}{c}-0.0047 \\
(-1.05)\end{array}$ & $\begin{array}{c}-0.0078 \\
(-1.59)\end{array}$ \\
\hline Constant & $\begin{array}{c}1.0089 * * * \\
(217.99)\end{array}$ & $\begin{array}{c}1.0087 * * * \\
(217.35)\end{array}$ & $\begin{array}{c}1.0068 * * * \\
(199.17)\end{array}$ & $\begin{array}{c}1.0177 * * * \\
(181.20)\end{array}$ & $\begin{array}{c}1.0181^{* * *} \\
(194.00)\end{array}$ & & & & & \\
\hline Rating effects & Yes & Yes & Yes & Yes & Yes & No & No & No & No & No \\
\hline Industry effects & Yes & Yes & Yes & Yes & Yes & No & No & No & No & No \\
\hline Year effects & Yes & Yes & Yes & Yes & Yes & No & No & No & No & No \\
\hline Observations & 2825 & 2825 & 2574 & 1369 & 1369 & 2825 & 2825 & 2574 & 1369 & 1369 \\
\hline
\end{tabular}




\section{Table 12: Do covenant-lite loans trade more frequently?}

The dependent variables are the average percentage of a loan's principal that is traded monthly and the percentage of months in which at least one loan participation fund trades the loan. Only trades by loan participation funds are tracked. The sample period is June 30, 2010 through April 30, 2015 with loan trading tracked until August 31, 2016. Loans were matched to the CRSP mutual fund database based on the security name indicated in CRSP. Initial \# LP Funds indicates the number of loan participation funds that hold shares in the loan after its first month of trading. If a loan is tracked by LSTA, but no loan participation fund reports holding the loan in CRSP, Initial \# LP Funds is set to zero for that loan. Standard errors are adjusted for clustering by firm and time. ${ }^{* * *}, * *$, and * indicate statistical significance at $1 \%, 5 \%$, and $10 \%$.

\section{Panel A: All trades}

\begin{tabular}{|c|c|c|c|c|c|c|c|c|c|c|}
\hline \multirow[t]{3}{*}{ Dep. variable: } & \multicolumn{5}{|c|}{ Monthly average \% principal traded } & \multicolumn{5}{|c|}{$\%$ months with trade } \\
\hline & \multicolumn{2}{|c|}{ All firms } & \multirow{2}{*}{$\begin{array}{l}\text { Rated firms } \\
\text { (3) }\end{array}$} & \multicolumn{2}{|c|}{ Registered firms } & \multicolumn{2}{|c|}{ All firms } & \multirow{2}{*}{$\begin{array}{l}\text { Rated firms } \\
\text { (8) }\end{array}$} & \multicolumn{2}{|c|}{ Registered firms } \\
\hline & (1) & (2) & & (4) & (5) & (6) & (7) & & (9) & (10) \\
\hline $\begin{array}{l}\text { Covenant lite } \\
\text { loan }\end{array}$ & $\begin{array}{c}0.297 * * * \\
(6.67)\end{array}$ & $\begin{array}{c}0.376^{* * *} \\
(6.71)\end{array}$ & $\begin{array}{c}0.294 * * * \\
(7.00)\end{array}$ & $\begin{array}{c}0.215^{* *} \\
(2.17)\end{array}$ & $\begin{array}{c}0.195^{* *} \\
(2.56)\end{array}$ & $\begin{array}{c}5.391 * * * \\
(5.55)\end{array}$ & $\begin{array}{c}7.302^{* * * *} \\
(6.99)\end{array}$ & $\begin{array}{c}5.000^{* * * *} \\
(4.96)\end{array}$ & $\begin{array}{l}2.951 \\
(1.34)\end{array}$ & $\begin{array}{l}3.077 \\
(1.46)\end{array}$ \\
\hline $\begin{array}{l}\text { Covenant lite } \\
\text { x Registered }\end{array}$ & & $\begin{array}{c}-0.164 * * * \\
(-2.73)\end{array}$ & & & & & $\begin{array}{c}-3.833^{* *} \\
(-2.05)\end{array}$ & & & \\
\hline Registered & & $\begin{array}{c}0.222^{* * * *} \\
(3.50)\end{array}$ & & & & & $\begin{array}{l}0.420 \\
(0.22)\end{array}$ & & & \\
\hline \# LP Funds & $\begin{array}{c}0.078 * * * \\
(5.32)\end{array}$ & $\begin{array}{c}0.077 * * * \\
(5.20)\end{array}$ & $\begin{array}{c}0.078 * * * \\
(5.36)\end{array}$ & $\begin{array}{c}0.058 * * * \\
(3.62)\end{array}$ & $\begin{array}{c}0.055^{* * * *} \\
(4.00)\end{array}$ & $\begin{array}{c}1.916^{* * *} \\
(11.47)\end{array}$ & $\begin{array}{c}1.924^{* * *} \\
(11.70)\end{array}$ & $\begin{array}{c}1.839 * * * \\
(10.26)\end{array}$ & $\begin{array}{c}1.782 * * * \\
(8.80)\end{array}$ & $\begin{array}{c}1.768 * * * \\
(8.72)\end{array}$ \\
\hline Ln(Assets) & & & & & $\begin{array}{c}0.339 * * \\
(2.10)\end{array}$ & & & & & $\begin{array}{l}1.094 \\
(0.83)\end{array}$ \\
\hline Leverage & & & & & $\begin{array}{l}0.442 \\
(1.34)\end{array}$ & & & & & $\begin{array}{c}4.947 * * \\
(2.52)\end{array}$ \\
\hline Current ratio & & & & & $\begin{array}{l}0.016 \\
(1.28)\end{array}$ & & & & & $\begin{array}{l}-0.220 \\
(-0.46)\end{array}$ \\
\hline
\end{tabular}




\begin{tabular}{|c|c|c|c|c|c|c|c|c|c|c|}
\hline $\begin{array}{l}\text { Ln(1+Coverage } \\
\text { Ratio) }\end{array}$ & & & & & $\begin{array}{l}0.034 \\
(0.58)\end{array}$ & & & & & $\begin{array}{l}-0.261 \\
(-0.27)\end{array}$ \\
\hline Tangibility & & & & & $\begin{array}{l}-0.161 \\
(-0.67)\end{array}$ & & & & & $\begin{array}{l}2.451 \\
(0.45)\end{array}$ \\
\hline Ln(Maturity) & $\begin{array}{l}0.336 * \\
(1.85)\end{array}$ & $\begin{array}{c}0.341^{*} \\
(1.92)\end{array}$ & $\begin{array}{l}0.346 * \\
(1.66)\end{array}$ & $\begin{array}{l}-0.035 \\
(-0.15)\end{array}$ & $\begin{array}{l}0.424 \\
(1.52)\end{array}$ & $\begin{array}{c}15.177^{* *} \\
(2.44)\end{array}$ & $\begin{array}{c}14.955^{* *} \\
(2.41)\end{array}$ & $\begin{array}{l}19.225^{* * *} \\
\quad(3.04)\end{array}$ & $\begin{array}{l}13.307 \\
(1.33)\end{array}$ & $\begin{array}{l}15.532 \\
(1.48)\end{array}$ \\
\hline Ln(Deal size) & $\begin{array}{c}-0.446 * * * \\
(-4.51)\end{array}$ & $\begin{array}{c}-0.460 * * * \\
(-4.65)\end{array}$ & $\begin{array}{c}-0.463^{* * *} \\
(-4.39)\end{array}$ & $\begin{array}{c}-0.445^{* * *} \\
(-4.20)\end{array}$ & $\begin{array}{c}-0.664 * * * \\
(-3.79)\end{array}$ & $\begin{array}{c}4.784 * * * \\
(7.79)\end{array}$ & $\begin{array}{l}4.916 * * * \\
(8.16)\end{array}$ & $\begin{array}{c}4.937^{* * * *} \\
(7.71)\end{array}$ & $\begin{array}{l}3.920 * * * \\
(3.73)\end{array}$ & $\begin{array}{c}3.054^{*} \\
(1.78)\end{array}$ \\
\hline Sponsored & $\begin{array}{l}-0.012 \\
(-0.11)\end{array}$ & $\begin{array}{l}0.032 \\
(0.29)\end{array}$ & $\begin{array}{l}-0.008 \\
(-0.07)\end{array}$ & $\begin{array}{l}0.110 \\
(1.15)\end{array}$ & $\begin{array}{l}0.084 \\
(0.89)\end{array}$ & $\begin{array}{l}-1.081 \\
(-1.10)\end{array}$ & $\begin{array}{l}-1.105 \\
(-1.41)\end{array}$ & $\begin{array}{l}-0.706 \\
(-0.68)\end{array}$ & $\begin{array}{l}-0.549 \\
(-0.27)\end{array}$ & $\begin{array}{l}-0.923 \\
(-0.41)\end{array}$ \\
\hline LBO & $\begin{array}{l}-0.026 \\
(-0.29)\end{array}$ & $\begin{array}{l}-0.028 \\
(-0.29)\end{array}$ & $\begin{array}{l}-0.014 \\
(-0.14)\end{array}$ & $\begin{array}{l}-0.086 \\
(-0.92)\end{array}$ & $\begin{array}{l}0.019 \\
(0.11)\end{array}$ & $\begin{array}{l}2.711 \\
(1.38)\end{array}$ & $\begin{array}{l}2.414 \\
(1.22)\end{array}$ & $\begin{array}{l}2.241 \\
(1.14)\end{array}$ & $\begin{array}{c}8.232^{* *} \\
(2.16)\end{array}$ & $\begin{array}{c}9.633^{* *} \\
(2.10)\end{array}$ \\
\hline Bond refinancing & $\begin{array}{l}0.091 \\
(0.46)\end{array}$ & $\begin{array}{l}0.065 \\
(0.33)\end{array}$ & $\begin{array}{l}0.063 \\
(0.32)\end{array}$ & $\begin{array}{l}-0.027 \\
(-0.32)\end{array}$ & $\begin{array}{l}-0.059 \\
(-0.57)\end{array}$ & $\begin{array}{l}-1.001 \\
(-0.43)\end{array}$ & $\begin{array}{l}-0.507 \\
(-0.23)\end{array}$ & $\begin{array}{l}-1.261 \\
(-0.52)\end{array}$ & $\begin{array}{l}-2.223 \\
(-0.64)\end{array}$ & $\begin{array}{l}-2.804 \\
(-0.80)\end{array}$ \\
\hline Revolver & $\begin{array}{c}-0.369 * * * \\
(-4.30)\end{array}$ & $\begin{array}{c}-0.342 * * * \\
(-3.94)\end{array}$ & $\begin{array}{c}-0.396 * * * \\
(-4.29)\end{array}$ & $\begin{array}{l}-0.092 \\
(-0.50)\end{array}$ & $\begin{array}{l}0.173 \\
(0.79)\end{array}$ & $\begin{array}{l}-2.426 * \\
(-1.95)\end{array}$ & $\begin{array}{c}-2.469 * * \\
(-2.07)\end{array}$ & $\begin{array}{c}-2.737 * * \\
(-2.03)\end{array}$ & $\begin{array}{l}-0.925 \\
(-0.48)\end{array}$ & $\begin{array}{l}0.113 \\
(0.05)\end{array}$ \\
\hline Term loan A & $\begin{array}{l}0.005 \\
(0.03)\end{array}$ & $\begin{array}{l}-0.020 \\
(-0.12)\end{array}$ & $\begin{array}{l}0.009 \\
(0.05)\end{array}$ & $\begin{array}{l}-0.217 \\
(-1.31)\end{array}$ & $\begin{array}{l}-0.177 \\
(-1.19)\end{array}$ & $\begin{array}{c}-8.427 * * * \\
(-3.98)\end{array}$ & $\begin{array}{c}-8.717 * * * \\
(-3.97)\end{array}$ & $\begin{array}{c}-8.331 * * * \\
(-3.46)\end{array}$ & $\begin{array}{c}-9.999 * * * \\
(-4.06)\end{array}$ & $\begin{array}{c}-9.654 * * * \\
(-3.37)\end{array}$ \\
\hline $\begin{array}{l}\text { Asset based } \\
\text { loan }\end{array}$ & $\begin{array}{l}0.129 \\
(1.56)\end{array}$ & $\begin{array}{l}0.113 \\
(1.33)\end{array}$ & $\begin{array}{l}0.115 \\
(1.29)\end{array}$ & $\begin{array}{l}-0.069 \\
(-0.41)\end{array}$ & $\begin{array}{l}-0.077 \\
(-0.38)\end{array}$ & $\begin{array}{l}1.087 \\
(0.92)\end{array}$ & $\begin{array}{l}0.988 \\
(0.87)\end{array}$ & $\begin{array}{l}1.172 \\
(1.09)\end{array}$ & $\begin{array}{l}-3.021 \\
(-1.06)\end{array}$ & $\begin{array}{l}-2.796 \\
(-0.95)\end{array}$ \\
\hline Middle market & $\begin{array}{c}-0.619 * * * \\
(-6.94)\end{array}$ & $\begin{array}{c}-0.594 * * * \\
(-7.29)\end{array}$ & $\begin{array}{c}-0.708^{* * *} \\
(-7.48)\end{array}$ & $\begin{array}{c}-0.638 * * * \\
(-6.94)\end{array}$ & $\begin{array}{c}-0.384^{* *} \\
(-2.07)\end{array}$ & $\begin{array}{c}-9.573 * * * \\
(-10.26)\end{array}$ & $\begin{array}{c}-9.285 * * * \\
(-11.87)\end{array}$ & $\begin{array}{c}-9.797 * * * \\
(-8.93)\end{array}$ & $\begin{array}{l}-5.598 \\
(-1.57)\end{array}$ & $\begin{array}{l}-4.072 \\
(-1.51)\end{array}$ \\
\hline $\begin{array}{l}\text { Second lien } \\
\text { facility }\end{array}$ & $\begin{array}{c}-0.109 * * \\
(-2.32)\end{array}$ & $\begin{array}{c}-0.089 * \\
(-1.89)\end{array}$ & $\begin{array}{c}-0.122 * * \\
(-2.37)\end{array}$ & $\begin{array}{c}-0.226^{* *} \\
(-2.43)\end{array}$ & $\begin{array}{l}-0.156 \\
(-1.63)\end{array}$ & $\begin{array}{l}-2.616 \\
(-1.54)\end{array}$ & $\begin{array}{c}-3.037 * \\
(-1.85)\end{array}$ & $\begin{array}{l}-2.347 \\
(-1.54)\end{array}$ & $\begin{array}{l}-5.668 \\
(-0.97)\end{array}$ & $\begin{array}{l}-5.706 \\
(-0.98)\end{array}$ \\
\hline Ln(Firm age) & $\begin{array}{c}0.068^{*} \\
(1.65)\end{array}$ & $\begin{array}{l}0.059 \\
(1.37)\end{array}$ & $\begin{array}{l}0.062 \\
(1.51)\end{array}$ & $\begin{array}{l}0.065 \\
(1.23)\end{array}$ & $\begin{array}{l}0.013 \\
(0.23)\end{array}$ & $\begin{array}{l}0.791 \\
(1.07)\end{array}$ & $\begin{array}{l}0.864 \\
(1.21)\end{array}$ & $\begin{array}{l}0.772 \\
(1.30)\end{array}$ & $\begin{array}{l}-0.431 \\
(-0.35)\end{array}$ & $\begin{array}{l}-0.389 \\
(-0.37)\end{array}$ \\
\hline
\end{tabular}




\begin{tabular}{lcccccccccc} 
Constant & $2.449^{* * *}$ & $2.432 * * *$ & $2.681^{* * *}$ & $2.726^{* * *}$ & 0.745 & -6.842 & -7.455 & $-25.069 *$ & -20.081 & -27.707 \\
& $(4.75)$ & $(4.76)$ & $(4.12)$ & $(3.57)$ & $(0.90)$ & $(-0.44)$ & $(-0.47)$ & $(-1.92)$ & $(-1.47)$ & $(-1.44)$ \\
Rating effects & Yes & Yes & Yes & Yes & Yes & Yes & Yes & Yes & Yes & Yes \\
Industry effects & Yes & Yes & Yes & Yes & Yes & Yes & Yes & Yes & Yes \\
Year effects & Yes & Yes & Yes & Yes & Yes & Yes & Yes & Yes & Yes & Yes \\
\hline Observations & 1875 & 1875 & 1757 & 821 & 821 & 1875 & 1875 & 1757 & 821 \\
\hline
\end{tabular}

\section{Panel B: Purchases only}

\begin{tabular}{|c|c|c|c|c|c|c|c|c|c|c|}
\hline \multirow[t]{3}{*}{ Dep. variable: } & \multicolumn{5}{|c|}{ Monthly average \% principal bought } & \multicolumn{5}{|c|}{$\%$ months with purchase } \\
\hline & \multicolumn{2}{|c|}{ All firms } & \multirow{2}{*}{$\begin{array}{l}\text { Rated firms } \\
\text { (3) }\end{array}$} & \multicolumn{2}{|c|}{ Registered firms } & \multicolumn{2}{|c|}{ All firms } & \multirow{2}{*}{$\begin{array}{l}\text { Rated firms } \\
\text { (8) }\end{array}$} & \multicolumn{2}{|c|}{ Registered firms } \\
\hline & (1) & (2) & & (4) & (5) & (6) & (7) & & (9) & $(10)$ \\
\hline $\begin{array}{l}\text { Covenant lite } \\
\text { loan }\end{array}$ & $\begin{array}{c}0.177 * * * \\
(5.48)\end{array}$ & $\begin{array}{c}0.224 * * * \\
(5.10)\end{array}$ & $\begin{array}{c}0.177^{* * *} \\
(5.65)\end{array}$ & $\begin{array}{c}0.125^{* *} \\
(2.33)\end{array}$ & $\begin{array}{c}0.118 * * * \\
(2.77)\end{array}$ & $\begin{array}{c}3.108 * * * \\
(2.94)\end{array}$ & $\begin{array}{c}4.272 * * * \\
(3.31)\end{array}$ & $\begin{array}{c}2.907^{* * *} \\
(2.73)\end{array}$ & $\begin{array}{l}1.793 \\
(0.96)\end{array}$ & $\begin{array}{l}1.809 \\
(1.10)\end{array}$ \\
\hline $\begin{array}{l}\text { Covenant lite } \\
\text { x Registered }\end{array}$ & & $\begin{array}{c}-0.097 * * * \\
(-2.66)\end{array}$ & & & & & $\begin{array}{l}-2.347^{*} \\
(-1.69)\end{array}$ & & & \\
\hline Registered & & $\begin{array}{c}0.106^{* * *} \\
(3.33)\end{array}$ & & & & & $\begin{array}{l}0.833 \\
(0.51)\end{array}$ & & & \\
\hline \# LP Funds & $\begin{array}{c}0.031 * * * \\
(4.88)\end{array}$ & $\begin{array}{c}0.031^{* * *} \\
(4.78)\end{array}$ & $\begin{array}{c}0.031 * * * \\
(4.95)\end{array}$ & $\begin{array}{c}0.022 * * * \\
(2.87)\end{array}$ & $\begin{array}{c}0.020 * * * \\
(3.18)\end{array}$ & $\begin{array}{c}2.064 * * * \\
(12.64)\end{array}$ & $\begin{array}{c}2.066^{* * *} \\
(13.10)\end{array}$ & $\begin{array}{c}2.001^{* * *} \\
(11.25)\end{array}$ & $\begin{array}{c}1.758 * * * \\
(11.39)\end{array}$ & $\begin{array}{c}1.739 * * * \\
(10.62)\end{array}$ \\
\hline Ln(Assets) & & & & & $\begin{array}{c}0.165^{* *} \\
(2.15)\end{array}$ & & & & & $\begin{array}{l}1.890^{*} \\
(1.67)\end{array}$ \\
\hline Leverage & & & & & $\begin{array}{l}0.201 \\
(1.19)\end{array}$ & & & & & $\begin{array}{l}5.670^{*} \\
(1.80)\end{array}$ \\
\hline Current ratio & & & & & $\begin{array}{c}0.014^{* * *} \\
(3.34)\end{array}$ & & & & & $\begin{array}{l}0.397 \\
(0.65)\end{array}$ \\
\hline
\end{tabular}




\begin{tabular}{|c|c|c|c|c|c|c|c|c|c|c|}
\hline $\begin{array}{l}\text { Ln(1+Coverage } \\
\text { Ratio) }\end{array}$ & & & & & $\begin{array}{l}0.014 \\
(0.46)\end{array}$ & & & & & $\begin{array}{l}-0.584 \\
(-1.02)\end{array}$ \\
\hline Tangibility & & & & & $\begin{array}{l}-0.010 \\
(-0.08)\end{array}$ & & & & & $\begin{array}{l}0.203 \\
(0.06)\end{array}$ \\
\hline Ln(Maturity) & $\begin{array}{c}0.218 * * \\
(2.41)\end{array}$ & $\begin{array}{c}0.219 * * \\
(2.48)\end{array}$ & $\begin{array}{c}0.230 * * \\
(2.25)\end{array}$ & $\begin{array}{l}0.033 \\
(0.37)\end{array}$ & $\begin{array}{l}0.249 * \\
(1.84)\end{array}$ & $\begin{array}{l}7.124 * \\
(1.84)\end{array}$ & $\begin{array}{l}7.029 * \\
(1.84)\end{array}$ & $\begin{array}{c}9.739 * * \\
(2.42)\end{array}$ & $\begin{array}{l}6.975 \\
(1.05)\end{array}$ & $\begin{array}{l}10.137 \\
(1.35)\end{array}$ \\
\hline Ln(Deal size) & $\begin{array}{c}-0.210^{* * *} \\
(-3.94)\end{array}$ & $\begin{array}{c}-0.216^{* * *} \\
(-4.01)\end{array}$ & $\begin{array}{c}-0.219 * * * \\
(-3.91)\end{array}$ & $\begin{array}{c}-0.206^{* * *} \\
(-3.58)\end{array}$ & $\begin{array}{c}-0.312^{* * *} \\
(-3.49)\end{array}$ & $\begin{array}{c}5.249 * * * \\
(11.23)\end{array}$ & $\begin{array}{c}5.274 * * * \\
(10.06)\end{array}$ & $\begin{array}{c}5.491 * * * \\
(10.59)\end{array}$ & $\begin{array}{l}5.552^{* * *} \\
(8.14)\end{array}$ & $\begin{array}{c}4.231^{* * *} \\
(3.55)\end{array}$ \\
\hline Sponsored & $\begin{array}{l}0.011 \\
(0.17)\end{array}$ & $\begin{array}{l}0.031 \\
(0.51)\end{array}$ & $\begin{array}{l}0.012 \\
(0.19)\end{array}$ & $\begin{array}{l}0.069 \\
(1.56)\end{array}$ & $\begin{array}{l}0.061 \\
(1.43)\end{array}$ & $\begin{array}{l}1.010 \\
(1.25)\end{array}$ & $\begin{array}{l}1.122 \\
(1.45)\end{array}$ & $\begin{array}{l}1.494 * \\
(1.74)\end{array}$ & $\begin{array}{l}1.717 \\
(1.24)\end{array}$ & $\begin{array}{l}1.134 \\
(0.79)\end{array}$ \\
\hline LBO & $\begin{array}{l}-0.015 \\
(-0.28)\end{array}$ & $\begin{array}{l}-0.017 \\
(-0.31)\end{array}$ & $\begin{array}{l}-0.007 \\
(-0.11)\end{array}$ & $\begin{array}{l}-0.043 \\
(-0.87)\end{array}$ & $\begin{array}{l}0.005 \\
(0.06)\end{array}$ & $\begin{array}{l}2.203 \\
(1.52)\end{array}$ & $\begin{array}{l}2.053 \\
(1.45)\end{array}$ & $\begin{array}{l}2.151 \\
(1.49)\end{array}$ & $\begin{array}{c}6.359 * * * \\
(3.88)\end{array}$ & $\begin{array}{c}8.409 * * * \\
(4.23)\end{array}$ \\
\hline Bond refinancing & $\begin{array}{l}-0.016 \\
(-0.17)\end{array}$ & $\begin{array}{l}-0.026 \\
(-0.27)\end{array}$ & $\begin{array}{l}-0.032 \\
(-0.34)\end{array}$ & $\begin{array}{c}-0.066^{*} \\
(-1.73)\end{array}$ & $\begin{array}{c}-0.085^{*} \\
(-1.69)\end{array}$ & $\begin{array}{l}-1.922 \\
(-0.98)\end{array}$ & $\begin{array}{l}-1.753 \\
(-0.90)\end{array}$ & $\begin{array}{l}-2.036 \\
(-1.02)\end{array}$ & $\begin{array}{l}-3.168 \\
(-1.30)\end{array}$ & $\begin{array}{l}-3.881 \\
(-1.58)\end{array}$ \\
\hline Revolver & $\begin{array}{c}-0.211^{* * * *} \\
(-3.89)\end{array}$ & $\begin{array}{c}-0.198 * * * \\
(-3.68)\end{array}$ & $\begin{array}{c}-0.226 * * * \\
(-4.03)\end{array}$ & $\begin{array}{l}-0.050 \\
(-0.55)\end{array}$ & $\begin{array}{l}0.077 \\
(0.73)\end{array}$ & $\begin{array}{c}-4.453^{* * *} \\
(-4.00)\end{array}$ & $\begin{array}{c}-4.398 * * * \\
(-3.99)\end{array}$ & $\begin{array}{c}-4.844 * * * \\
(-4.70)\end{array}$ & $\begin{array}{c}-2.654 * * * \\
(-4.00)\end{array}$ & $\begin{array}{l}-1.062 \\
(-0.85)\end{array}$ \\
\hline Term loan A & $\begin{array}{l}0.005 \\
(0.06)\end{array}$ & $\begin{array}{l}-0.008 \\
(-0.10)\end{array}$ & $\begin{array}{l}0.010 \\
(0.12)\end{array}$ & $\begin{array}{l}-0.101 \\
(-1.17)\end{array}$ & $\begin{array}{l}-0.078 \\
(-0.97)\end{array}$ & $\begin{array}{c}-7.030 * * * \\
(-3.68)\end{array}$ & $\begin{array}{c}-7.244 * * * \\
(-3.73)\end{array}$ & $\begin{array}{c}-7.056 * * * \\
(-3.22)\end{array}$ & $\begin{array}{c}-9.444 * * * \\
(-3.69)\end{array}$ & $\begin{array}{c}-9.004^{* * *} \\
(-3.11)\end{array}$ \\
\hline $\begin{array}{l}\text { Asset based } \\
\text { loan }\end{array}$ & $\begin{array}{l}0.061 \\
(1.34)\end{array}$ & $\begin{array}{l}0.053 \\
(1.14)\end{array}$ & $\begin{array}{l}0.056 \\
(1.14)\end{array}$ & $\begin{array}{l}-0.040 \\
(-0.46)\end{array}$ & $\begin{array}{l}-0.044 \\
(-0.42)\end{array}$ & $\begin{array}{l}0.309 \\
(0.34)\end{array}$ & $\begin{array}{l}0.215 \\
(0.23)\end{array}$ & $\begin{array}{l}0.483 \\
(0.57)\end{array}$ & $\begin{array}{l}-3.483^{*} \\
(-1.81)\end{array}$ & $\begin{array}{l}-3.289 \\
(-1.48)\end{array}$ \\
\hline Middle market & $\begin{array}{c}-0.321^{* * *} \\
(-5.57)\end{array}$ & $\begin{array}{c}-0.308^{* * *} \\
(-5.86)\end{array}$ & $\begin{array}{c}-0.369 * * * \\
(-5.78)\end{array}$ & $\begin{array}{c}-0.366^{* * *} \\
(-7.57)\end{array}$ & $\begin{array}{c}-0.242 * * * \\
(-3.20)\end{array}$ & $\begin{array}{c}-7.086^{* * *} \\
(-5.84)\end{array}$ & $\begin{array}{c}-6.874 * * * \\
(-5.98)\end{array}$ & $\begin{array}{c}-7.691 * * * \\
(-6.53)\end{array}$ & $\begin{array}{c}-6.592^{* *} \\
(-2.20)\end{array}$ & $\begin{array}{c}-4.754 * * \\
(-2.29)\end{array}$ \\
\hline $\begin{array}{l}\text { Second lien } \\
\text { facility }\end{array}$ & $\begin{array}{c}-0.052 * \\
(-1.79)\end{array}$ & $\begin{array}{l}-0.044 \\
(-1.54)\end{array}$ & $\begin{array}{c}-0.054^{*} \\
(-1.75)\end{array}$ & $\begin{array}{c}-0.126^{* * *} \\
(-2.71)\end{array}$ & $\begin{array}{c}-0.092 * \\
(-1.87)\end{array}$ & $\begin{array}{c}-2.298 * \\
(-1.67)\end{array}$ & $\begin{array}{c}-2.447^{*} \\
(-1.83)\end{array}$ & $\begin{array}{l}-2.321^{*} \\
(-1.71)\end{array}$ & $\begin{array}{l}-4.408 \\
(-0.85)\end{array}$ & $\begin{array}{l}-4.211 \\
(-0.84)\end{array}$ \\
\hline Ln(Firm age) & $\begin{array}{c}0.041^{* *} \\
(2.00)\end{array}$ & $\begin{array}{c}0.038^{*} \\
(1.78)\end{array}$ & $\begin{array}{c}0.038^{*} \\
(1.92)\end{array}$ & $\begin{array}{c}0.052 * * \\
(2.22)\end{array}$ & $\begin{array}{l}0.026 \\
(1.15)\end{array}$ & $\begin{array}{l}0.374 \\
(0.86)\end{array}$ & $\begin{array}{l}0.386 \\
(0.83)\end{array}$ & $\begin{array}{l}0.244 \\
(0.59)\end{array}$ & $\begin{array}{l}-0.198 \\
(-0.21)\end{array}$ & $\begin{array}{l}-0.307 \\
(-0.36)\end{array}$ \\
\hline
\end{tabular}




\begin{tabular}{|c|c|c|c|c|c|c|c|c|c|c|}
\hline Constant & $\begin{array}{c}1.049 * * * \\
(4.65)\end{array}$ & $\begin{array}{c}1.038 * * * \\
(4.69)\end{array}$ & $\begin{array}{c}1.152^{* * *} \\
(3.81)\end{array}$ & $\begin{array}{c}1.175^{* * * *} \\
(3.29)\end{array}$ & $\begin{array}{l}0.193 \\
(0.43)\end{array}$ & $\begin{array}{c}-26.247^{* * *} \\
(-3.10)\end{array}$ & $\begin{array}{c}-26.595^{* * *} \\
(-3.06)\end{array}$ & $\begin{array}{c}-42.242^{* * *} \\
(-4.38)\end{array}$ & $\begin{array}{c}-33.667 * * * \\
(-3.91)\end{array}$ & $\begin{array}{c}-47.116^{* * *} \\
(-3.00)\end{array}$ \\
\hline Rating effects & Yes & Yes & Yes & Yes & Yes & Yes & Yes & Yes & Yes & Yes \\
\hline Industry effects & Yes & Yes & Yes & Yes & Yes & Yes & Yes & Yes & Yes & Yes \\
\hline Year effects & Yes & Yes & Yes & Yes & Yes & Yes & Yes & Yes & Yes & Yes \\
\hline Observations & 1875 & 1875 & 1757 & 821 & 821 & 1875 & 1875 & 1757 & 821 & 821 \\
\hline
\end{tabular}




\section{Table 13: Do secondary market quotes indicate more liquidity for covenant-lite loans?}

In Panel A, the dependent variable is the average of the difference between the average bid quote and the average ask quote for a loan divided by the average ask quote multiplied by 100 . In Panel B, the dependent variable is the average number of brokers that supply a quote to the Thomson Reuters/LSTA Mark-to-Market pricing service. Four time periods are examined: the first three months after the loan's launch date, the first year, the second year, and the third year. The sample includes only those loans that were originated between January 2010 and April 2015 and are tracked by the Thomson Reuters/LSTA Mark-to-Market pricing service. If more than one of a loan's tranches is traded, we use the bid-ask spread of the largest tranche. Initial \# LP Funds indicates the number of loan participation funds that hold shares in the loan after its first month of trading. If a loan is tracked by LSTA, but no loan participation fund reports holding the loan in CRSP, Initial \# LP Funds is set to zero for that loan. Average bid-ask midpoint denotes the average of the bid-ask midpoint in cents on the dollar. Revolver, Term Loan A, Term Loan C, Term Loan D or other, and Second Lien are indicator variables capturing the type of the loan tranche that is tracked in LSTA. Term Loans B act as the base group. Columns (1) through (4) include all loans, columns (5) through (8) exclude loans whose bid-ask midpoint is below 90 cents on the dollar at some point during the respective period as well as debtor-in-possession loans. All bid-ask spreads are winsorized at the $1^{\text {st }}$ and $99^{\text {th }}$ percentiles. Standard errors are adjusted for clustering by firm and time. ***, **, and * indicate statistical significance at $1 \%, 5 \%$, and $10 \%$.

Panel A: Bid-ask spreads

\begin{tabular}{|c|c|c|c|c|c|c|c|c|}
\hline & \multicolumn{4}{|c|}{ All loans } & \multicolumn{4}{|c|}{ Non-distressed loans } \\
\hline & $\begin{array}{c}3 \text { months } \\
\text { (1) }\end{array}$ & $\begin{array}{l}\text { Year } 1 \\
(2)\end{array}$ & $\begin{array}{c}\text { Year } 2 \\
(3)\end{array}$ & $\begin{array}{c}\text { Year } 3 \\
(4)\end{array}$ & $\begin{array}{c}3 \text { months } \\
\text { (5) }\end{array}$ & $\begin{array}{l}\text { Year } 1 \\
(6)\end{array}$ & $\begin{array}{c}\text { Year } 2 \\
(7)\end{array}$ & $\begin{array}{c}\text { Year } 3 \\
(8)\end{array}$ \\
\hline $\begin{array}{l}\text { Covenant lite } \\
\text { loan }\end{array}$ & $\begin{array}{c}-0.0375^{* *} \\
(-1.98)\end{array}$ & $\begin{array}{c}-0.0408^{* *} \\
(-2.37)\end{array}$ & $\begin{array}{l}-0.0073 \\
(-0.20)\end{array}$ & $\begin{array}{c}-0.1391 \\
(-1.31)\end{array}$ & $\begin{array}{c}-0.0407 * * \\
(-2.35)\end{array}$ & $\begin{array}{c}-0.0499 * * \\
(-2.34)\end{array}$ & $\begin{array}{c}-0.0464^{* *} \\
(-2.56)\end{array}$ & $\begin{array}{c}-0.0512 * * \\
(-2.36)\end{array}$ \\
\hline $\begin{array}{l}\text { Covenant lite } \\
\text { x Registered }\end{array}$ & $\begin{array}{c}0.0149 * \\
(1.92)\end{array}$ & $\begin{array}{c}0.0445 * * \\
(2.56)\end{array}$ & $\begin{array}{l}-0.0492 \\
(-0.85)\end{array}$ & $\begin{array}{c}0.0728 * * * \\
(2.79)\end{array}$ & $\begin{array}{c}0.0211^{* *} \\
(2.27)\end{array}$ & $\begin{array}{c}0.0524^{* * *} \\
(2.96)\end{array}$ & $\begin{array}{l}0.0154 \\
(0.95)\end{array}$ & $\begin{array}{l}0.0387 \\
(0.69)\end{array}$ \\
\hline Registered & $\begin{array}{c}-0.0297 * * * \\
(-3.72)\end{array}$ & $\begin{array}{c}-0.0365 * * * \\
(-3.04)\end{array}$ & $\begin{array}{l}0.0032 \\
(0.08)\end{array}$ & $\begin{array}{c}-0.0520 \\
(-1.10)\end{array}$ & $\begin{array}{c}-0.0321^{* * *} \\
(-6.81)\end{array}$ & $\begin{array}{c}-0.0404 * * * \\
(-3.46)\end{array}$ & $\begin{array}{c}-0.0465 \\
(-1.21)\end{array}$ & $\begin{array}{l}-0.0465 \\
(-1.06)\end{array}$ \\
\hline $\begin{array}{l}\text { Initial \# LP } \\
\text { Funds }\end{array}$ & $\begin{array}{c}-0.0022 \\
(-1.05)\end{array}$ & $\begin{array}{c}-0.0003 \\
(-0.15)\end{array}$ & $\begin{array}{c}-0.0032 * \\
(-1.95)\end{array}$ & $\begin{array}{c}-0.0115^{* * * *} \\
(-2.80)\end{array}$ & $\begin{array}{c}-0.0021 \\
(-1.22)\end{array}$ & $\begin{array}{c}-0.0009 \\
(-0.59)\end{array}$ & $\begin{array}{c}-0.0025 * * * \\
(-3.62)\end{array}$ & $\begin{array}{c}-0.0034 * * * \\
(-3.44)\end{array}$ \\
\hline
\end{tabular}




\begin{tabular}{|c|c|c|c|c|c|c|c|c|}
\hline $\begin{array}{l}\text { Average bid- } \\
\text { ask midpoint }\end{array}$ & $\begin{array}{c}-0.0895^{* * *} \\
(-6.03)\end{array}$ & $\begin{array}{c}-0.1032 * * * \\
(-8.77)\end{array}$ & $\begin{array}{c}-0.1085^{* * *} \\
(-13.10)\end{array}$ & $\begin{array}{c}-0.1207 * * * \\
(-26.31)\end{array}$ & $\begin{array}{c}-0.1012^{* * *} \\
(-6.01)\end{array}$ & $\begin{array}{c}-0.1110 * * * \\
(-6.53)\end{array}$ & $\begin{array}{c}-0.1432 * * * \\
(-4.98)\end{array}$ & $\begin{array}{c}-0.1555^{* * *} \\
(-9.10)\end{array}$ \\
\hline Ln(Maturity) & $\begin{array}{c}-0.0861^{*} \\
(-1.84)\end{array}$ & $\begin{array}{l}-0.0405 \\
(-1.03)\end{array}$ & $\begin{array}{l}-0.0962 \\
(-1.46)\end{array}$ & $\begin{array}{l}0.0432 \\
(0.19)\end{array}$ & $\begin{array}{l}-0.0630 \\
(-1.07)\end{array}$ & $\begin{array}{c}-0.0606 \\
(-0.99)\end{array}$ & $\begin{array}{c}-0.1240^{* *} \\
(-2.28)\end{array}$ & $\begin{array}{c}-0.1468 * \\
(-1.80)\end{array}$ \\
\hline Ln(Deal size) & $\begin{array}{c}-0.0744^{* * *} \\
(-5.57)\end{array}$ & $\begin{array}{c}-0.0984 * * * \\
(-3.71)\end{array}$ & $\begin{array}{c}-0.1325^{* * * *} \\
(-5.02)\end{array}$ & $\begin{array}{c}-0.1523 * \\
(-1.73)\end{array}$ & $\begin{array}{c}-0.0736 * * * \\
(-5.57)\end{array}$ & $\begin{array}{c}-0.0800 * * * \\
(-4.14)\end{array}$ & $\begin{array}{c}-0.0686^{* * *} \\
(-6.49)\end{array}$ & $\begin{array}{c}-0.0459 * * * \\
(-3.05)\end{array}$ \\
\hline Sponsored & $\begin{array}{c}-0.0051 \\
(-0.20)\end{array}$ & $\begin{array}{l}-0.0205 \\
(-1.41)\end{array}$ & $\begin{array}{c}-0.0091 \\
(-0.35)\end{array}$ & $\begin{array}{l}0.0352 \\
(0.78)\end{array}$ & $\begin{array}{l}-0.0030 \\
(-0.13)\end{array}$ & $\begin{array}{l}-0.0216 \\
(-1.35)\end{array}$ & $\begin{array}{c}-0.0651^{* *} \\
(-2.12)\end{array}$ & $\begin{array}{c}-0.0546 * * * \\
(-3.43)\end{array}$ \\
\hline LBO & $\begin{array}{c}0.0127 * \\
(1.82)\end{array}$ & $\begin{array}{c}0.0019 \\
(0.18)\end{array}$ & $\begin{array}{l}0.0110 \\
(0.48)\end{array}$ & $\begin{array}{c}-0.0920^{* *} \\
(-2.02)\end{array}$ & $\begin{array}{c}0.0122 * * \\
(2.06)\end{array}$ & $\begin{array}{c}-0.0064 \\
(-0.49)\end{array}$ & $\begin{array}{c}0.0206 \\
(1.00)\end{array}$ & $\begin{array}{l}-0.0106 \\
(-0.40)\end{array}$ \\
\hline $\begin{array}{l}\text { Bond } \\
\text { refinancing }\end{array}$ & $\begin{array}{c}-0.0210 * * \\
(-1.96)\end{array}$ & $\begin{array}{c}-0.0421 * * \\
(-2.42)\end{array}$ & $\begin{array}{c}-0.1443 * * * \\
(-4.89)\end{array}$ & $\begin{array}{c}-0.2941^{* *} \\
(-2.19)\end{array}$ & $\begin{array}{c}-0.0274 * * \\
(-2.31)\end{array}$ & $\begin{array}{c}-0.0403 * \\
(-1.72)\end{array}$ & $\begin{array}{c}-0.0814^{* * *} \\
(-5.60)\end{array}$ & $\begin{array}{c}-0.1464 * * * \\
(-3.48)\end{array}$ \\
\hline Revolver & $\begin{array}{c}0.4866 * * * \\
(6.53)\end{array}$ & $\begin{array}{c}0.4711^{* * * *} \\
(7.61)\end{array}$ & $\begin{array}{c}0.6005^{* * *} \\
(3.15)\end{array}$ & $\begin{array}{c}0.4610^{* *} \\
(2.54)\end{array}$ & $\begin{array}{c}0.4709 * * * \\
(5.94)\end{array}$ & $\begin{array}{c}0.4703^{* * * *} \\
(4.75)\end{array}$ & $\begin{array}{c}0.3230 * * * \\
(4.11)\end{array}$ & $\begin{array}{c}0.2046^{* *} \\
(2.09)\end{array}$ \\
\hline Term Loan A & $\begin{array}{l}0.0187 \\
(0.64)\end{array}$ & $\begin{array}{c}0.0425 \\
(0.96)\end{array}$ & $\begin{array}{l}0.0180 \\
(0.39)\end{array}$ & $\begin{array}{c}0.2036 \\
(0.85)\end{array}$ & $\begin{array}{c}0.0184 \\
(0.57)\end{array}$ & $\begin{array}{l}0.0302 \\
(0.92)\end{array}$ & $\begin{array}{c}0.0272 \\
(0.86)\end{array}$ & $\begin{array}{c}0.0271 \\
(0.68)\end{array}$ \\
\hline $\begin{array}{l}\text { Asset based } \\
\text { loan }\end{array}$ & $\begin{array}{c}-0.0287 \\
(-1.14)\end{array}$ & $\begin{array}{c}0.0231 \\
(0.85)\end{array}$ & $\begin{array}{c}0.0484 * * \\
(2.16)\end{array}$ & $\begin{array}{c}0.1249 * \\
(1.72)\end{array}$ & $\begin{array}{c}-0.0259 \\
(-1.13)\end{array}$ & $\begin{array}{l}0.0031 \\
(0.12)\end{array}$ & $\begin{array}{c}0.0300 \\
(0.87)\end{array}$ & $\begin{array}{l}0.0555 \\
(1.27)\end{array}$ \\
\hline Middle market & $\begin{array}{c}0.0371 * \\
(1.87)\end{array}$ & $\begin{array}{c}0.0648 * * * \\
(4.57)\end{array}$ & $\begin{array}{l}0.0579 \\
(1.22)\end{array}$ & $\begin{array}{l}0.0933 \\
(0.62)\end{array}$ & $\begin{array}{c}0.0365 * \\
(1.79)\end{array}$ & $\begin{array}{c}0.0683^{* * * *} \\
(5.09)\end{array}$ & $\begin{array}{c}0.0838 * * * \\
(3.52)\end{array}$ & $\begin{array}{c}0.0882 * * * \\
(3.06)\end{array}$ \\
\hline Second lien & $\begin{array}{c}0.2416^{* * *} \\
(5.10)\end{array}$ & $\begin{array}{c}0.2608^{* * * *} \\
(7.00)\end{array}$ & $\begin{array}{c}0.3156^{* * *} \\
(2.92)\end{array}$ & $\begin{array}{c}0.5746^{* *} \\
(2.25)\end{array}$ & $\begin{array}{c}0.2369 * * * \\
(5.30)\end{array}$ & $\begin{array}{c}0.2775^{* * *} \\
\quad(7.88)\end{array}$ & $\begin{array}{c}0.3777 * * * \\
(8.52)\end{array}$ & $\begin{array}{c}0.3315^{* * *} \\
(8.67)\end{array}$ \\
\hline Ln(Firm age) & $\begin{array}{c}-0.0175^{* *} \\
(-1.98)\end{array}$ & $\begin{array}{c}-0.0133 \\
(-1.51)\end{array}$ & $\begin{array}{c}-0.0160 * * \\
(-2.13)\end{array}$ & $\begin{array}{c}-0.0024 \\
(-0.18)\end{array}$ & $\begin{array}{c}-0.0186 * * \\
(-2.15)\end{array}$ & $\begin{array}{c}-0.0124 \\
(-1.62)\end{array}$ & $\begin{array}{c}-0.0082 \\
(-1.23)\end{array}$ & $\begin{array}{c}-0.0357 * * * \\
(-3.21)\end{array}$ \\
\hline
\end{tabular}




\begin{tabular}{|c|c|c|c|c|c|c|c|c|}
\hline Constant & $\begin{array}{l}10.2841^{* * *} \\
\quad(6.61)\end{array}$ & $\begin{array}{l}11.8125^{* * * *} \\
(9.71)\end{array}$ & $\begin{array}{l}12.8498^{* * *} \\
(13.64)\end{array}$ & $\begin{array}{l}14.0008^{* * *} \\
(64.51)\end{array}$ & $\begin{array}{l}11.4106^{* * * *} \\
(6.63)\end{array}$ & $\begin{array}{l}12.6505^{* * *} \\
(7.20)\end{array}$ & $\begin{array}{l}15.8533^{* * *} \\
(5.56)\end{array}$ & $\begin{array}{l}17.1462^{* * *} \\
(9.62)\end{array}$ \\
\hline Rating effects & Yes & Yes & Yes & Yes & Yes & Yes & Yes & Yes \\
\hline Industry effects & Yes & Yes & Yes & Yes & Yes & Yes & Yes & Yes \\
\hline Year effects & Yes & Yes & Yes & Yes & Yes & Yes & Yes & Yes \\
\hline Observations & 1275 & 1336 & 1236 & 882 & 1260 & 1270 & 1098 & 733 \\
\hline
\end{tabular}

Panel B: Number of quotes

\begin{tabular}{|c|c|c|c|c|c|c|c|c|}
\hline & \multicolumn{4}{|c|}{ All loans } & \multicolumn{4}{|c|}{ Non-distressed loans } \\
\hline & $\begin{array}{c}3 \text { months } \\
\text { (1) }\end{array}$ & $\begin{array}{c}\text { Year } 1 \\
\text { (2) }\end{array}$ & $\begin{array}{c}\text { Year } 2 \\
\text { (3) }\end{array}$ & $\begin{array}{c}\text { Year } 3 \\
(4)\end{array}$ & $\begin{array}{c}3 \text { months } \\
\text { (5) }\end{array}$ & $\begin{array}{c}\text { Year } 1 \\
(6)\end{array}$ & $\begin{array}{c}\text { Year } 2 \\
(7)\end{array}$ & $\begin{array}{c}\text { Year } 3 \\
\text { (8) }\end{array}$ \\
\hline $\begin{array}{l}\text { Covenant lite } \\
\text { loan }\end{array}$ & $\begin{array}{c}0.1625^{*} \\
(1.67)\end{array}$ & $\begin{array}{c}0.1842 * * * \\
(2.67)\end{array}$ & $\begin{array}{c}0.0298 \\
(0.30)\end{array}$ & $\begin{array}{c}0.0198 \\
(0.25)\end{array}$ & $\begin{array}{c}0.1903^{*} \\
(1.92)\end{array}$ & $\begin{array}{c}0.2215^{* * * *} \\
(3.37)\end{array}$ & $\begin{array}{c}0.0681 \\
(0.56)\end{array}$ & $\begin{array}{c}0.0530 \\
(0.78)\end{array}$ \\
\hline $\begin{array}{l}\text { Covenant lite } \\
\text { x Registered }\end{array}$ & $\begin{array}{c}0.0853 \\
(0.59)\end{array}$ & $\begin{array}{c}0.1416 \\
(1.30)\end{array}$ & $\begin{array}{c}0.3358 * * * \\
(2.60)\end{array}$ & $\begin{array}{c}0.2688 * * \\
(2.08)\end{array}$ & $\begin{array}{c}0.0672 \\
(0.46)\end{array}$ & $\begin{array}{c}0.1690 \\
(1.60)\end{array}$ & $\begin{array}{c}0.3196^{*} \\
(1.65)\end{array}$ & $\begin{array}{c}0.2623 \\
(1.39)\end{array}$ \\
\hline Registered & $\begin{array}{c}0.4003 * * * \\
(3.54)\end{array}$ & $\begin{array}{c}0.3725 * * * \\
\quad(5.45)\end{array}$ & $\begin{array}{c}0.3205^{* * * *} \\
(2.94)\end{array}$ & $\begin{array}{c}0.1782 * * \\
\quad(2.27)\end{array}$ & $\begin{array}{c}0.4238 * * * \\
(3.64)\end{array}$ & $\begin{array}{c}0.3814^{* * * *} \\
(5.37)\end{array}$ & $\begin{array}{c}0.2869 * * \\
(2.37)\end{array}$ & $\begin{array}{c}0.1580 \\
(1.46)\end{array}$ \\
\hline $\begin{array}{l}\text { Initial \# LP } \\
\text { Funds }\end{array}$ & $\begin{array}{c}0.0217^{*} \\
(1.70)\end{array}$ & $\begin{array}{c}0.0344 * * * \\
(4.55)\end{array}$ & $\begin{array}{c}0.0356 * * * \\
(5.39)\end{array}$ & $\begin{array}{c}0.0358 * * \\
(2.20)\end{array}$ & $\begin{array}{c}0.0218 * \\
(1.76)\end{array}$ & $\begin{array}{c}0.0368 * * * \\
(5.02)\end{array}$ & $\begin{array}{c}0.0366 * * * \\
(3.54)\end{array}$ & $\begin{array}{c}0.0349 * \\
(1.93)\end{array}$ \\
\hline $\begin{array}{l}\text { Average bid- } \\
\text { ask midpoint }\end{array}$ & $\begin{array}{c}0.0878 * \\
(1.82)\end{array}$ & $\begin{array}{c}0.0116 \\
(1.37)\end{array}$ & $\begin{array}{c}0.0061 \\
(1.52)\end{array}$ & $\begin{array}{c}0.0104 * * \\
(2.33)\end{array}$ & $\begin{array}{c}0.1128 \\
(1.48)\end{array}$ & $\begin{array}{c}-0.0115 \\
(-0.26)\end{array}$ & $\begin{array}{c}0.0087 \\
(0.18)\end{array}$ & $\begin{array}{c}0.0394 \\
(0.86)\end{array}$ \\
\hline Ln(Maturity) & $\begin{array}{c}0.1745 \\
(0.40)\end{array}$ & $\begin{array}{c}0.1697 \\
(0.39)\end{array}$ & $\begin{array}{c}0.1628 \\
(0.81)\end{array}$ & $\begin{array}{c}0.0339 \\
(0.12)\end{array}$ & $\begin{array}{c}-0.0528 \\
(-0.13)\end{array}$ & $\begin{array}{c}-0.0155 \\
(-0.03)\end{array}$ & $\begin{array}{c}0.2164 \\
(0.70)\end{array}$ & $\begin{array}{c}-0.1180 \\
(-0.36)\end{array}$ \\
\hline
\end{tabular}




\begin{tabular}{|c|c|c|c|c|c|c|c|c|}
\hline Ln(Deal size) & $\begin{array}{c}1.2247^{* * * *} \\
(9.17)\end{array}$ & $\begin{array}{c}1.2462 * * * \\
(9.66)\end{array}$ & $\begin{array}{c}1.0877 * * * \\
(11.55)\end{array}$ & $\begin{array}{c}1.0630 * * * \\
(6.43)\end{array}$ & $\begin{array}{c}1.2250 * * * \\
(9.24)\end{array}$ & $\begin{array}{c}1.2271^{* * *} \\
(8.83)\end{array}$ & $\begin{array}{c}1.0863 * * * \\
(10.43)\end{array}$ & $\begin{array}{c}1.0759 * * * \\
(6.14)\end{array}$ \\
\hline Sponsored & $\begin{array}{c}0.2071^{* *} \\
(2.12)\end{array}$ & $\begin{array}{c}0.2195^{* *} \\
(2.17)\end{array}$ & $\begin{array}{c}0.2258^{*} \\
(1.91)\end{array}$ & $\begin{array}{c}0.2593^{* *} \\
(2.23)\end{array}$ & $\begin{array}{c}0.1935^{* *} \\
(2.22)\end{array}$ & $\begin{array}{c}0.2292^{* *} \\
(2.28)\end{array}$ & $\begin{array}{c}0.2580^{* *} \\
(2.16)\end{array}$ & $\begin{array}{c}0.2955^{* *} \\
(2.22)\end{array}$ \\
\hline LBO & $\begin{array}{l}0.1394 \\
(1.10)\end{array}$ & $\begin{array}{l}0.0267 \\
(0.23)\end{array}$ & $\begin{array}{c}-0.0073 \\
(-0.08)\end{array}$ & $\begin{array}{c}-0.0453 \\
(-0.38)\end{array}$ & $\begin{array}{l}0.1597 \\
(1.21)\end{array}$ & $\begin{array}{l}0.0578 \\
(0.53)\end{array}$ & $\begin{array}{c}-0.0346 \\
(-0.30)\end{array}$ & $\begin{array}{c}-0.0131 \\
(-0.09)\end{array}$ \\
\hline $\begin{array}{l}\text { Bond } \\
\text { refinancing }\end{array}$ & $\begin{array}{l}0.1257 \\
(1.19)\end{array}$ & $\begin{array}{c}-0.0176 \\
(-0.22)\end{array}$ & $\begin{array}{l}0.1413 \\
(0.99)\end{array}$ & $\begin{array}{c}0.6066^{* *} \\
(2.44)\end{array}$ & $\begin{array}{c}0.1431 \\
(1.57)\end{array}$ & $\begin{array}{l}-0.0287 \\
(-0.38)\end{array}$ & $\begin{array}{l}0.0667 \\
(0.55)\end{array}$ & $\begin{array}{l}0.7753^{* * * *} \\
\quad(5.87)\end{array}$ \\
\hline Revolver & $\begin{array}{c}-2.2222 * * * \\
(-5.24)\end{array}$ & $\begin{array}{c}-2.7151^{* * *} \\
(-6.85)\end{array}$ & $\begin{array}{c}-2.7026^{* * *} \\
(-11.39)\end{array}$ & $\begin{array}{c}-2.4230 * * * \\
(-6.98)\end{array}$ & $\begin{array}{c}-2.2867 * * * \\
(-4.69)\end{array}$ & $\begin{array}{c}-2.7307 * * * \\
(-6.06)\end{array}$ & $\begin{array}{c}-2.6582^{* * *} \\
(-9.17)\end{array}$ & $\begin{array}{c}-2.2731^{* * *} \\
(-8.55)\end{array}$ \\
\hline Term Loan A & $\begin{array}{c}-1.4079 * * * \\
(-2.89)\end{array}$ & $\begin{array}{c}-1.4642 * * * \\
(-3.22)\end{array}$ & $\begin{array}{c}-1.3347 * * * \\
(-3.90)\end{array}$ & $\begin{array}{c}-0.9319 * * * \\
(-3.10)\end{array}$ & $\begin{array}{c}-1.4352 * * * \\
(-2.91)\end{array}$ & $\begin{array}{c}-1.4770^{* * * *} \\
(-3.14)\end{array}$ & $\begin{array}{c}-1.2761^{* * *} \\
(-3.61)\end{array}$ & $\begin{array}{c}-0.9232 * * * \\
(-3.18)\end{array}$ \\
\hline $\begin{array}{l}\text { Asset based } \\
\text { loan }\end{array}$ & $\begin{array}{c}-0.2403 * * * \\
(-3.16)\end{array}$ & $\begin{array}{c}-0.3216 * * * \\
(-2.93)\end{array}$ & $\begin{array}{c}-0.4484^{* * *} \\
(-7.20)\end{array}$ & $\begin{array}{l}-0.3914 \\
(-12.03)\end{array}$ & $\begin{array}{c}-0.2275^{* * * *} \\
(-3.13)\end{array}$ & $\begin{array}{c}-0.3162 * * * \\
(-2.97)\end{array}$ & $\begin{array}{c}-0.4334 * * * \\
(-4.73)\end{array}$ & $\begin{array}{c}-0.4053 * * * \\
(-9.90)\end{array}$ \\
\hline Middle market & $\begin{array}{c}-0.0096 \\
(-0.06)\end{array}$ & $\begin{array}{c}0.0083 \\
(0.07)\end{array}$ & $\begin{array}{c}-0.0583 \\
(-0.84)\end{array}$ & $\begin{array}{l}-0.0568 \\
(-0.70)\end{array}$ & $\begin{array}{l}-0.0140 \\
(-0.09)\end{array}$ & $\begin{array}{c}0.0099 \\
(0.09)\end{array}$ & $\begin{array}{l}-0.0838 \\
(-0.80)\end{array}$ & $\begin{array}{l}-0.0405 \\
(-0.40)\end{array}$ \\
\hline Second lien & $\begin{array}{c}-0.4619 * * \\
(-2.08)\end{array}$ & $\begin{array}{c}-0.6126^{* *} \\
(-2.34)\end{array}$ & $\begin{array}{c}-0.4888^{*} \\
(-1.70)\end{array}$ & $\begin{array}{c}-0.3256 \\
(-1.17)\end{array}$ & $\begin{array}{c}-0.4498^{* *} \\
(-2.13)\end{array}$ & $\begin{array}{c}-0.6445^{* * *} \\
(-2.82)\end{array}$ & $\begin{array}{c}-0.6604^{* * *} \\
(-3.13)\end{array}$ & $\begin{array}{c}-0.4284^{*} \\
(-1.73)\end{array}$ \\
\hline Ln(Firm age) & $\begin{array}{l}0.0365 \\
(0.65)\end{array}$ & $\begin{array}{c}0.0484 \\
(1.21)\end{array}$ & $\begin{array}{l}0.0354 \\
(0.92)\end{array}$ & $\begin{array}{c}-0.0049 \\
(-0.11)\end{array}$ & $\begin{array}{l}0.0426 \\
(0.76)\end{array}$ & $\begin{array}{c}0.0409 \\
(1.02)\end{array}$ & $\begin{array}{c}0.0524 \\
(1.10)\end{array}$ & $\begin{array}{l}0.0044 \\
(0.09)\end{array}$ \\
\hline Constant & $\begin{array}{c}-15.1022 * * * \\
(-2.64)\end{array}$ & $\begin{array}{l}-7.2416^{* * *} \\
(-5.65)\end{array}$ & $\begin{array}{l}-5.4377 * * * \\
(-9.08)\end{array}$ & $\begin{array}{l}-5.3794 * * * \\
(-5.64)\end{array}$ & $\begin{array}{l}-17.1944^{* *} \\
(-2.10)\end{array}$ & $\begin{array}{l}-4.2987 \\
(-0.96)\end{array}$ & $\begin{array}{l}-5.8612 \\
(-1.30)\end{array}$ & $\begin{array}{l}-7.9784 * \\
(-1.81)\end{array}$ \\
\hline Rating effects & Yes & Yes & Yes & Yes & Yes & Yes & Yes & Yes \\
\hline
\end{tabular}




\begin{tabular}{lccccccccc} 
Industry effects & Yes & Yes & Yes & Yes & Yes & Yes & Yes & Yes \\
Year effects & Yes & Yes & Yes & Yes & Yes & Yes & Yes & Yes \\
\hline Observations & 1275 & 1336 & 1236 & 882 & 1260 & 1270 & 1098 & 733 \\
\hline
\end{tabular}

